\title{
Development of a Mud-Pulse High-Temperature Measurement-While-Drilling (MWD) System
}

\section{Final Report}

\author{
September 31, 1999 - January 31, 2002
}

By:

John H. Cohen (Maurer Technology Inc.) Greg Deskins (Maurer Technology Inc.)

William Motion (Sperry Sun)

Jay Martin (Sperry Sun)

January 2002

DE-AC26-97FT34345

Maurer Technology Inc.

2916 West T.C. Jester

Houston, TX 77018

Sperry Sun

3000 North Sam Houston Parkway East

Houston, TX 77032

TR02-16 


\section{Disclaimer}

This report was prepared as an account of work sponsored by an agency of the United States Government. Neither the United States Government nor any agency thereof, nor any of their employees, makes any warranty, express or implied, or assumes any legal liability or responsibility for the accuracy, completeness, or usefulness of any information, apparatus, product, or process disclosed, or represents that its use would not infringe privately owned rights. Reference herein to any specific commercial product, process, or service by trade name, trademark, manufacturer, or otherwise does not necessarily constitute or imply its endorsement, recommendation, or favoring by the United States Government or any agency thereof. The views and opinions of authors expressed herein do not necessarily state or reflect hose of the United States Government or any agency thereof. 


\section{Table of Contents}

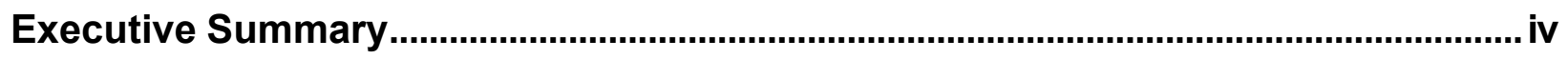

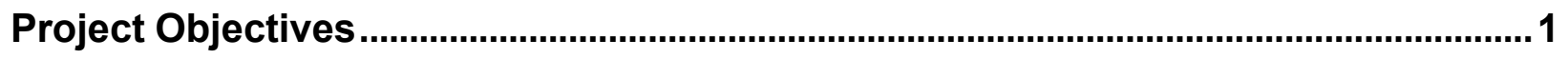

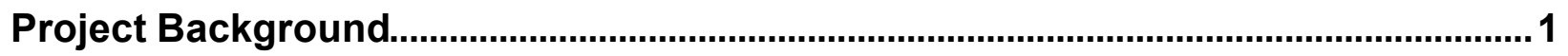

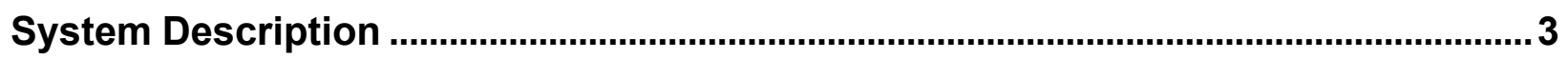

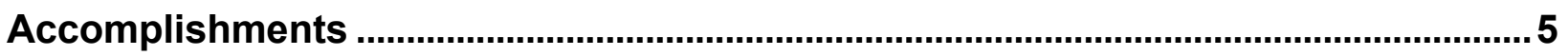

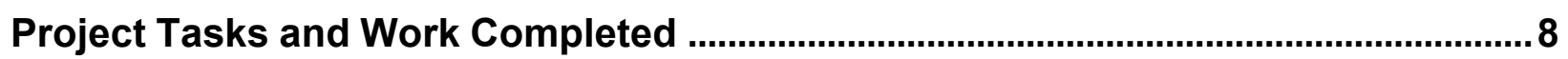

Field Test

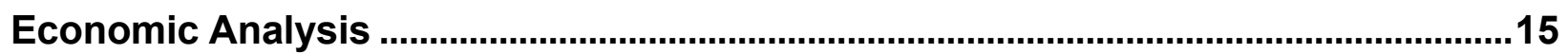

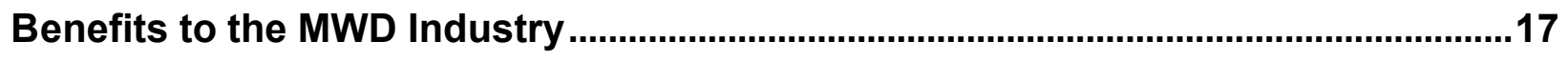

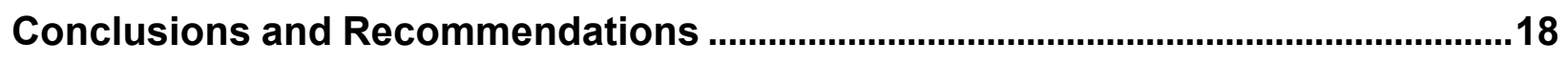

Appendix A: Field Test Report 


\section{Executive Summary}

The overall program objective is to develop a mud-pulse measurement-whiledrilling (MWD) tool for oil and gas drilling operations that can be used where downhole temperatures are as high as $195^{\circ} \mathrm{C}\left(383^{\circ} \mathrm{F}\right)$. The work was planned to be completed in two phases: Phase I and an optional Phase II.

The objectives of Phase I were first to identify critical components of existing MWD systems that can or cannot operate at $195^{\circ} \mathrm{C}$. For components not able to meet the higher standard, one of several strategies was pursued: 1) locate high-temperature replacement components, 2) develop new designs that eliminate the unavailable components, or 3) use cooling to keep components at acceptable operating temperatures (under 195으. $\mathrm{C}$. New designs and components were then tested under high temperatures in the laboratory. The final goal of Phase I was to assemble two high-temperature MWD prototype tools and test each in at least one low-temperature well to verify total system performance.

Phase II was also envisioned as part of this development. Its objective would be to test the two new high-temperature MWD prototype tools in wells being drilled in the United States where the bottom-hole temperatures were $195^{\circ} \mathrm{C}$ (or the highest temperatures attainable).

The high-temperature MWD tool Figure is is designed to send directional and formation data to the surface via mud pulses, to aid in the drilling of guided wellbores. The modules that comprise the tool are housed in sealed barrels that protect the electronics from exposure to down-hole fluids and pressures. These pressure barrels are hung inside a non-magnetic collar located above the drilling assembly.

A number of significant accomplishments were achieved during the course of the Phase I project, including:

- Tested two MWD strings for function in an oven at $195^{\circ} \mathrm{C}$

- Conducted field test of prototype $195^{\circ} \mathrm{C}$ MWD tool (at well temperatures up to $\left.140-180^{\circ} \mathrm{C}\right)$

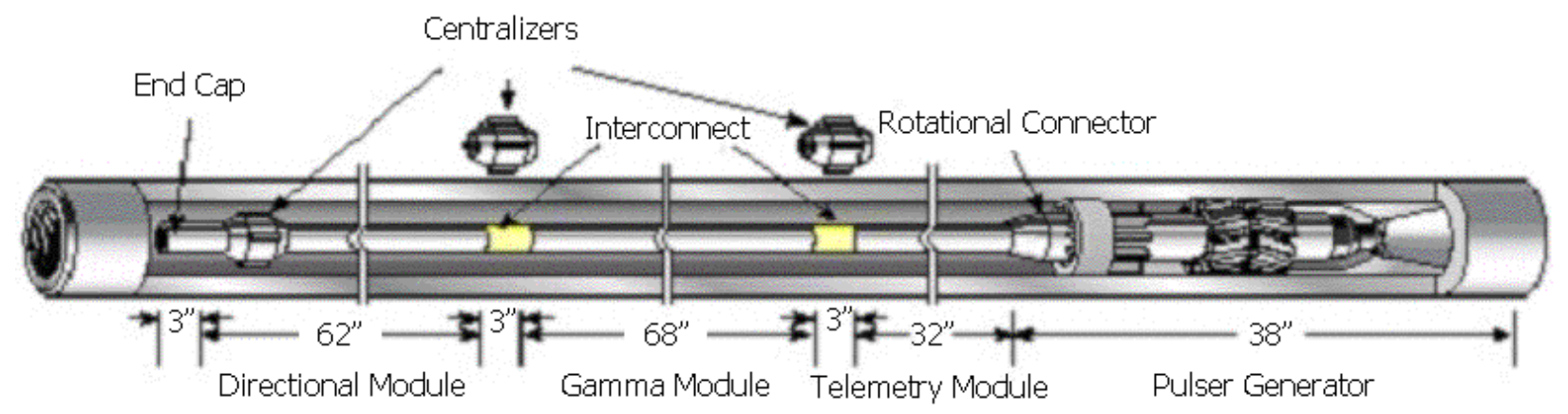

Figure i. High-Temperature MWD Tool 
- Tested ELCON hybrid chip with processor, clock, and memory in a custom package for 700 hours at $200^{\circ} \mathrm{C}$

- Contracted with APS Technology to conduct study of thermoelectric cooling of downhole electronics

- Conducted successful Peltier cooling test with APS Technology

- Tested and improved the electronics of Sperry Sun's Geiger Muller-based gamma detector for operation at $195^{\circ} \mathrm{C}$

- Developed two high-temperature magnetometers (one in-house, one with Tensor)

- Encouraged outside source to develop lithium/magnesium high-temperature batteries (operating temperature of 125 to $215^{\circ} \mathrm{C}$ )

One of this project's greatest achievements was improvement in Sperry Sun's current tool with changes made as a direct result of work performed under this project. These improvements have resulted in longer life and a more robust MWD tool at the previous temperature rating of $175^{\circ} \mathrm{C}$, as well as at higher temperatures.

A field test of two prototype $195^{\circ} \mathrm{C}$ MWD tools was conducted in Lavaca County, Texas. The purpose of this operation was to provide directional services on a sidetrack of a straight hole. The sidetrack was to intersect the formation up-dip above the water/gas interface. In addition, the gamma tool provided formation data including seam tops and thickness. Results from these field tests indicate progress in the development of a $195^{\circ} \mathrm{C}$ tool. Although the pulsers failed downhole in both tools, failure of the pulsers was determined to be from mechanical rather than electrical causes.

Analysis of the economics of the $195^{\circ} \mathrm{C}$ tool highlights the greatest obstacle to future commercialization. Costs to screen individual components, then subassemblies, and finally completed tools for high-temperature operations are very high. Tests to date also show a relatively short life for high-temperature tools - on the order of 300 hours. These factors mean that the daily cost of the tool will be higher ( 3 to 5 times more) than a conventional tool.

Sperry Sun and the MWD industry have benefited from this program in the following areas:

Pulser Improvements. Several improvements were implemented in "O" ring selection, oil selection, and other areas.

Magnetometer and Calibration Improvements. Work on the magnetometer included upgrades to Sperry Sun magnetometers. This has led to improvements to the design of Sperry Sun's existing magnetometers, which will be beneficial across all directional work. 
Software Improvements, Resetting and Power-Up Problems. Software changes that were required in the downhole code and tool programming code provided another opportunity to improve the robustness of the downhole tool string.

Identification of Circuit Design Weaknesses. While screening components for high temperatures, unexpected problems were observed, including voltage reference drift problems and capacitor failures. Voltage reference drift is another candidate for high-temperature semiconductor technology. The capacitor issue identified a failure in the $\mathrm{QC}$ process of production.

The project has helped in clearly demonstrating the limitations of the methods Sperry Sun is currently using to produce high-temperature tools. Based on this work, they are considering the available high-temperature technologies and looking at approaches for introducing these technologies over the longer term.

\section{Conclusions and Recommendations}

1. Results of this development effort showed that, while it is possible to build a mudpulse MWD tool that can operate at $195^{\circ} \mathrm{C}$, performance of the current tool is probably not sufficient for commercial success.

2. Industry's current R\&D goals and perception of future MWD requirements do not focus on operations in hotter and deeper formations.

3. Due to the extensive testing required and the high percentage of failing components, use of a binning qualification process to build high-temperature $\left(195^{\circ} \mathrm{C}\right)$ MWD tools is cost-prohibitive.

4. Increasing the operating temperature of current MWD tools to $195^{\circ} \mathrm{C}$ and above will require development of a new platform for the electronics used in these tools. This new platform will be based on silicon-on-insulator (SOI) components.

5. There are several hindrances to the development of SOI tools for the MWD industry. Most are economic, rather than technological factors.

6. DOE leadership and partership with industry can play a significant role in encouraging the development of high-temperature MWD tools to prepare for the future.

7. A critical leadership role for the DOE is to convince the industry that future gas reserves will be produced from high-temperature reservoirs. 


\section{Development of a Mud-Pulse High-Temperature Measurement-While-Drilling (MWD) System}

\section{Project Objectives}

The overall objective of this program is to develop a mud-pulse measurementwhile-drilling (MWD) tool for oil and gas drilling operations that can be used where downhole temperatures are as high as $195^{\circ} \mathrm{C}\left(383^{\circ} \mathrm{F}\right)$. The tool is to include a hightemperature $\left(195^{\circ} \mathrm{C}\right)$ gamma-ray detector to serve as the formation identification component of the MWD system. Other components in the assembly include triaxial accelerometer and magnetometer suites to provide directional data.

The work was planned to be completed in two phases: Phase I and an optional Phase II. The objectives of Phase I were to:

- Identify critical components of existing MWD systems that can or cannot operate at $195^{\circ} \mathrm{C}$

- For those components that cannot meet the new $195^{\circ} \mathrm{C}$ limit, employ one of the following strategies to achieve required performance: 1) locate high-temperature replacement components, 2) develop new designs that eliminate the unavailable components, or 3) use cooling to keep components at acceptable operating temperatures (under 195을

- Test new designs and components under high temperatures in the laboratory

- Assemble two high-temperature MWD prototype tools and test each in at least one low-temperature well to verify total system performance

Phase II was also envisioned as part of this development. Its objective would be to test the two new high-temperature MWD prototype tools in wells being drilled in the United States where the bottom-hole temperatures were 195ㅇ (or the highest temperature attainable in current U.S. deep drilling operations, although at least 185ㄷ). Up to five directional/horizontal wells were planned to be used for the field tests to establish system reliability and the tool's mean-time-between-failure (MTBF) performance.

\section{Project Background}

This project was co-proposed by Maurer Technology Inc. (MTI) and Halliburton Energy Services (HES) through its Halliburton Drilling Systems Division. During the course of the project, HES and Dresser Industries merged. The Federal Trade Commission, in their approval of the merger, required Halliburton Drilling Systems to be spun off as a separate company. This new company, called Pathfinder, continued with 
the improvement of HES's MWD tools, but had limited funding and could not meet the program's cost-sharing requirements. Halliburton's MWD and LWD services would now be handled by Sperry Sun, a former Dresser Industries company. This significantly impacted the project. Under the original proposal, HES's HDS-1 MWD tool was to be upgraded for operation in temperatures up to $195^{\circ} \mathrm{C}$. HES had significant corporate motivation to achieve this objective since their standard tool could only be operated up to $150^{\circ} \mathrm{C}$ and was below the latest industry standards in reliability. The engineering approach to increase temperature limits was to first test the existing tool using highlyaccelerated life testing (HALT) equipment to identify components that would function at higher temperatures and components that would fail at higher temperatures. Once components that fail were identified, improved replacement components were to be located and tested. If these could not be found, new designs were to be developed to replace the missing components. This MWD system development process was well under way when Halliburton and Dresser Industries merged.

The first effect of the merger was a complete work stoppage on the project. Halliburton-Sperry Sun now owned the Solar 175 tool previously developed by Sperry Sun. This tool's upper operating temperature is $175^{\circ} \mathrm{C}$. The new company thus had different incentives with respect to continuing the project. It took one year to resolve how the contractual obligations were to be meet. In the end, Halliburton-Sperry Sun decided to continue with the project, but would upgrade the existing Solar 175 tool for operations to $195^{\circ} \mathrm{C}$.

The new engineering approach was a continuation of Sperry Sun's current "binning" process. In this method, tool components are tested at the desired working conditions. Component lots found to perform satisfactorily are set aside ("binned"). Lots not meeting required performance levels are returned to the manufacturer or discarded. After binning, assemblies and sub-assemblies of components are then tested. This process is very costly, since many components and sub-assemblies must be tested to find enough components that meet acceptable standards. Assembly testing also includes determining failure modes by post-mortem examinations. In cases where component binning or change-out would not achieve required performance, the board design was modified. However, this was considered a last resort, and only minor changes were to be acceptable. The objective was to produce an upgraded Solar 175 tool, not a new $195^{\circ} \mathrm{C}$ tool.

The effort was also impacted by a complete change in Halliburton personnel assigned to the project. As would be expected, it took time before the new team came "up to speed" on the goals and objectives of he project, and progress could resume. This was further complicated as changeovers in tools and procedures were enacted under the merged companies. In addition, since the Sperry Sun tool was already rated to $175^{\circ} \mathrm{C}$ (best in the industry at that time) compared to $150^{\circ} \mathrm{C}$ for HES's HDS-1 tool, the high-temperature MWD market was considered after the merger as a niche market rather than as an opportunity to become the industry leader in high-temperature MWD. These factors led to minimal resources being allocated to the project and slowed its progress. Fortunately, interest in the effort was soon heightened after an important 
customer independently approached Sperry Sun and requested MWD tools with higher temperature capabilities.

The merger resulted in some of the work accomplished previously during the project by HES later becoming superfluous to the Halliburton-Sperry Sun effort. That work is still reported here since it was good science and the knowledge gained could help in development with the Solar 195 tool. Other planned activities no longer needed to be pursued since a solution already existed in the merged companies. An example of this was the development of a high-temperature gamma detector based on Geiger Muller tubes. Sperry Sun already had this type of detector available, so that effort was stopped after the merger.

At the end of the effort, Sperry Sun constructed two prototype MWD tools that were successfully tested in the laboratory at $195^{\circ} \mathrm{C}$ and then field tested in Phase I. Results of these field tests are described in this report.

\section{System Description}

The high-temperature measurement-while-drilling (MWD) tool (Figure 1) is designed to send directional and formation data to the surface via mud pulses, to aid in the drilling of guided wellbores. The modules that comprise the tool are housed in sealed barrels that protect the electronics from exposure to down-hole fluids and pressures. These pressure barrels are hung inside a non-magnetic collar located above the drilling assembly. Descriptions of the modules and their functions are presented below.

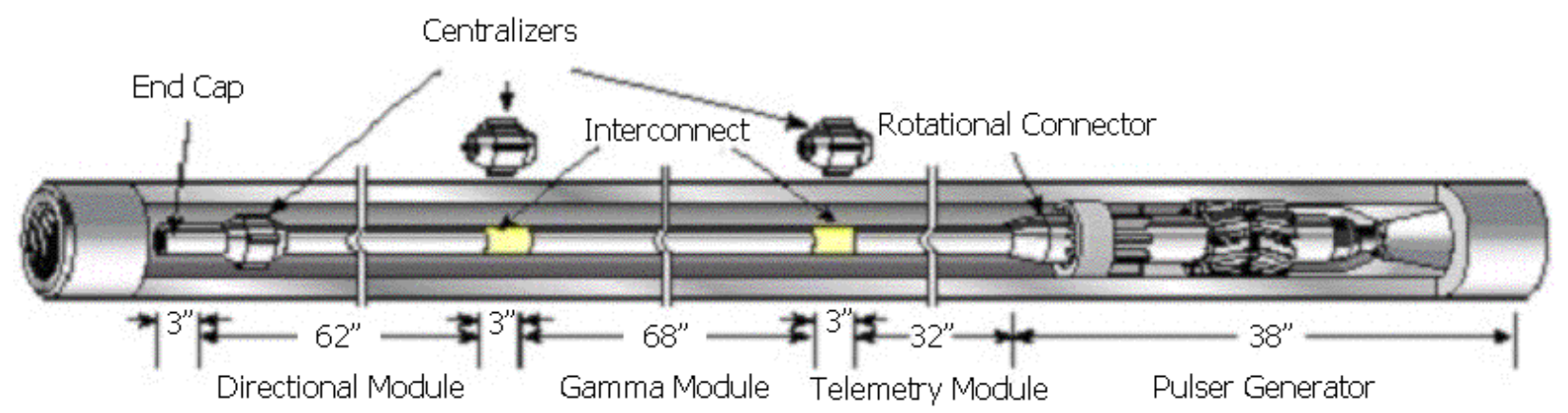

Figure 1. High-Temperature MWD Tool

Telemetry Module (TM). The telemetry module controls the entire tool. It communicates with other modules over the communications line. Data are gathered from the gamma module and directional module, formatted for transmission, and stored in random access memory (RAM) on the TM board. These data can be downloaded at the surface even if they are not relayed via the pulser. The TM also conditions the electric power from the pulser/generator for use by the other modules. The TM uses $512 \mathrm{kB}$ of static RAM divided into $8 \mathrm{kB}$ blocks for continuous memory storage. 
Gamma Module (GM). The gamma module measures naturally occurring gamma radiation from formations encountered. It incorporates Geiger Muller tubes because they are rugged and able to survive high temperatures. Conventional gamma sensors based on scintillation technology cannot be used in high-temperature environments because detector performance degrades rapidly at elevated temperatures. Three stacked banks of four Geiger Mueller tubes each make up the sensor section of the GM. None of these tubes are redundant, but are what is required to achieve a statistically accurate count. The Geiger Muller tubes contain a gas that becomes ionized when gamma energy passes through it. This allows high voltage to pass between an anode and cathode, which is recorded as a single pulse. The pulses from all the tubes are added to provide the gamma count. The gamma count is used to determine formation type and transition depths between formations. In horizontal drilling, gamma data are used to steer the drilling assembly within the producing formation.

Pulser/Generator. The pulser module has two functions: to generate electrical power and to restrict the mud flow to create a pressure pulse that can be detected at the surface. It is always connected to the TM and is unique among the modules in this aspect. The pulser contains turbine blades that are driven by the flowing mud to turn a generator and a small hydraulic pump. Power from the generator is sent to the TM for conditioning prior to being sent to the remainder of the tool. The hydraulic pump is used to operate a poppet valve that blocks the flow of mud in the drill string, thereby creating a pressure pulse. The TM controls the pulser operations and encodes data into the pulses that are received and decoded at the surface using a pressure transducer and computer. The pulser is typically found at the top of the MWD stack.

Battery Module (BM). The battery module provides power to the tool when there is no flow of drilling fluid to operate the generator. The MWD tool can operate without a BM, but then could not store data when the rig pumps were off. The BM allows operation during these periods. High-temperature lithium batteries are used in the BM. Halliburton worked with Battery Engineering to develop higher temperature batteries for this project.

Directional Module (DM). The directional module uses magnetometers and accelerometers to measure the compass direction of the bottom-hole assembly and the angle of the hole. These data along with depth are then used to calculate the trajectory of the well. The DM is usually placed near the bottom of the MWD stack so that it will be as close as possible to the drill bit. 


\section{Accomplishments}

A number of accomplishments were achieved during the course of the project. These are listed below. (More detail is provided in other sections of this report.)

- Tested two MWD strings for function in an oven at $195^{\circ} \mathrm{C}$

- Conducted field test of prototype 195ㄷ MWD tool (at well temperatures from 140 to $\left.180^{\circ} \mathrm{C}\right)$

- Tested ELCON hybrid chip with processor, clock, and memory in a custom package for 700 hours at $200^{\circ} \mathrm{C}$ (see Figure 3)

- Contracted with APS Technology to conduct study of thermoelectric cooling of downhole electronics

- Conducted Peltier cooling test with APS Technology

- Tested and improved the electronics of Sperry Sun's Geiger Muller-based gamma detector for operation at $195^{\circ} \mathrm{C}$

- Developed two high-temperature magnetometers (one in-house, one with Tensor)

- Encouraged outside source to develop lithium/magnesium high-temperature batteries (operating temperature of 125 to $215^{\circ} \mathrm{C}$ )

One of this project's greatest achievements was improvement in Sperry Sun's current tool with changes made as a direct result of work performed under this project. Table 1 lists many of the modifications. These have resulted in improved life and a more robust MWD tool at the previous temperature rating of $175^{\circ} \mathrm{C}$, as well as at higher temperatures.

\section{Table 1. Solar 175 System Upgrades to Increase Operating Temperature to $195^{\circ} \mathrm{C}$}

I. Directional Module (DM)

- Increased the life of the DC-DC converter and reduced the amount of 5-volt drift via modifications to the DM power board.

- Special software was used to create the thermal models at $195^{\circ} \mathrm{C}$.

- Developed magnetometer that operated at $200^{\circ} \mathrm{C}$ at Cheltenham Engineering Center. 
- Worked with Honeywell to develop and test magnetometer package for operation up to $200^{\circ} \mathrm{C}$.

- Worked with JAE to provide accelerometer package for operation up to $200^{\circ} \mathrm{C}$.

- Changed the download of HC811 code. The appropriate code is stored in all 4 banks of the external EEPROM. This corrects reset problems at temperatures above 175ㅇ. $\mathrm{C}$.

- Added a brown-out monitor to the power board to insure that HC811 is reset properly.

- Upgraded the CMOS analog switch on the power board.

\section{Processor Board}

- No hardware was changed in the processor board to reach the $195^{\circ} \mathrm{C}$ temperatures.

- Changed software to add additional time delay during initialization to allow processor to recover from a Power On Reset when operating above $190^{\circ} \mathrm{C}$.

- The only circuit that does not operate reliably at temperatures above $180^{\circ} \mathrm{C}$ is the Real Time Clock.

\section{Power Board}

- To solve problems with voltage drift of the precision 5volt reference with time and temperature, it was necessary to decrease the amount of output current the device must source. This increased the life of the reference to approximately 150 hours at $200^{\circ} \mathrm{C}$. A reference manufactured by a different vendor was located, that required minor modification to work in Sperry Sun circuit.

Five-volt reference used in the power supply circuits prevents drift with temperature and time. Tested three different parts; the ceramic part did not fail after approximately 500 hours at $200^{\circ} \mathrm{C}$. Built two $195^{\circ} \mathrm{C}$ telemetry modules and gamma modules using the new reference chip.

- Increased main power input electrolytic capacitor life to 300 hours at $195^{\circ} \mathrm{C}$ by lowering the generator supply from 24 volts to 22 volts.

\section{Gamma Module (GM)}

- Screened timer chip to operate at higher temperatures. During tests on the first GM's built, we discovered that the high-voltage supply would shut down at temperatures above $183^{\circ} \mathrm{C}$. A timer chip used in the high-voltage supply circuit was found to be the cause. We screened different date 
codes on these devices to find those that would work above the required $195^{\circ} \mathrm{C}$. Also tested two other timers from different vendors that will also work in this circuit. Qualification of these new devices is still in process. The GM's built for this project used the screened timers.

- The 5-volt reference chip was changed to the new type.

\section{Battery Module}

- Changed 5-volt reference chip to a Maxim brand.

- Changed 5-volt supply from just a reference chip to a reference chip with a buffer and current pump system.

- Change of voltage measurements for Battery and Sub-bus by the PIC A/D. Changed divider networks from high impedance to less than $10 \mathrm{k}-\mathrm{Ohms}$.

- Changed instantaneous current measurement impedance to PIC A/D by decreasing from $50 \mathrm{k}-\mathrm{Ohms}$ to $10 \mathrm{k}-\mathrm{Ohms}$.

- Added $10 \mathrm{k}$-Ohm input impedance lines to PIC on the pulse accumulation measurement. This improves long-term average current draw measurement reliability in the PIC.

\section{Pulser}

There were three areas (wear, oil compensation, and sealing) where improvements were made to the pulser for high temperatures.

A. Wear

- Conical rams redesigned with increased contact area for reduced wear

- Conical rams retained with anti-rotation spider to eliminate coil spring wear

- Angle plate bearing races changed to high-grade M50 bearing steel

- Angle plate bearing elements changed to Silicon Nitride balls and precision machined cage

- Tapered roller bearing mounting changed to minimize mechanical shock related spalling

- Oil changed to Mobil SHC 1025 to eliminate viscosity breakdown

- 25-micron filter and auger to circulate oil and trap particles 
- Metal screen (70 micron) oil filter with conical rams

B. Oil Compensation

- Piston pressure compensation system replaced boot-style design

- Kemlon caps to reduce oil volume

- Pump outer case

C. Sealing

- Changed to 90-durometer O-rings

- Tee-seals on the bulkhead

- HPHT feed-through connectors for the bulkhead

\section{Project Tasks and Work Completed}

Following are listed the Phase I tasks with a discussion of the work conducted under each task. Work on many tasks was accomplished both before and after the Halliburton/Sperry Sun merger. To clarify this distinction, work performed before the merger is referred to as "Halliburton" and work after the merger as "Sperry Sun."

Task 1. High-Temperature Characterization of HDS-1 MWD/Gamma Tool

Both Halliburton and Sperry Sun used HALT (highly-accelerated life testing) to characterize the HDS-1 and Solar 175 tools. Figure 2 shows the HALT equipment used by Sperry Sun. HALT allows accelerated life testing of components by subjecting them to vibration and temperature fluctuations. HALT equipment allows desired cycles and rates to be programmed for each test. The product is monitored during the test for function. When components fail, they can be replaced and testing continued, if desired. Good correlation between HALT and field life has been observed.

Halliburton and Sperry Sun were both able to identify components or circuit designs that failed as temperatures were increased to $200^{\circ} \mathrm{C}$. For circuit design failures, eliminating components or altering the design addressed the shortcomings. Other failures required that new components be substituted for those that could not meet the temperature requirements.

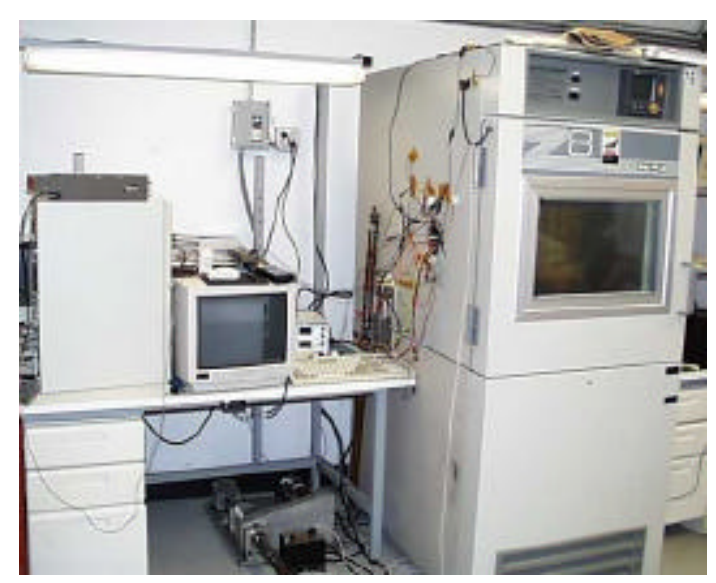

Figure 2. Sperry Sun HALT Equipment 
Task 2. Evaluation of High-Temperature Components

Work under this task highlighted a fundamental difference in the approaches of Halliburton and Sperry Sun. Halliburton's goal was to identify, test, and use components that were either designed to operate at higher temperatures or had been specially modified to operate at higher temperatures. Sperry Sun chose to keep the same components (when possible), but identify batches from the manufacturer that functioned at elevated temperatures. One reason for the difference in this philosophy is that Halliburton's then-current tool was initially only rated to $150^{\circ} \mathrm{C}$ and they realized that their product was falling behind the industry standard as a whole. Sperry Sun's tool currently achieved a rating of $175^{\circ} \mathrm{C}$ and was a leader in the industry for temperature

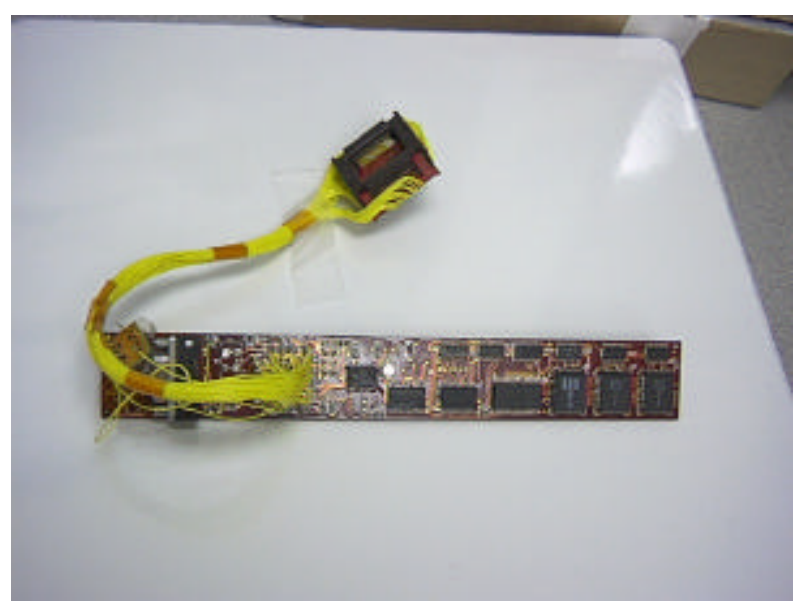

Figure 3. ELCON Hybrid Processor Chip for Test capabilities. Sperry Sun believed that they had already identified components with superior temperature performance and that the project's goal to increase temperature capability to $195^{\circ} \mathrm{C}$ could be accomplished by locating exceptional batches of components that could survive even higher temperatures.

Halliburton was successful in finding several components that demonstrated improved high-temperature performance. Many of the components were radiation hardened. A major concern at the onset of the project was the performance of the microprocessor and memory chips. Halliburton located a hybrid chip manufactured by ELCON Technology of Phoenix, Arizona, that was successfully tested at $200^{\circ} \mathrm{C}$ for over 700 hours. The test was halted at the time of the merger, and was never completed or repeated. Since the chip did not meet Sperry Sun's configuration, it was not considered in their development. Figure 3 shows the hybrid chip on a test board. It has been isolated so that only the chip will be placed in the test oven and not the circuit used to operate the chip.

Task 2a. Design of Active Cooling System

At part of the contract, Halliburton undertook and paid for the work under this subtask, which involved analytical and experimental work on an active cooling system. Halliburton contracted this work to APS Technology of Cromwell, Connecticut. They developed an analytical model to simulate cooling of an MWD system and a dummy board, using resistance heating to simulate electrical components. Figure $\mathbf{4}$ shows

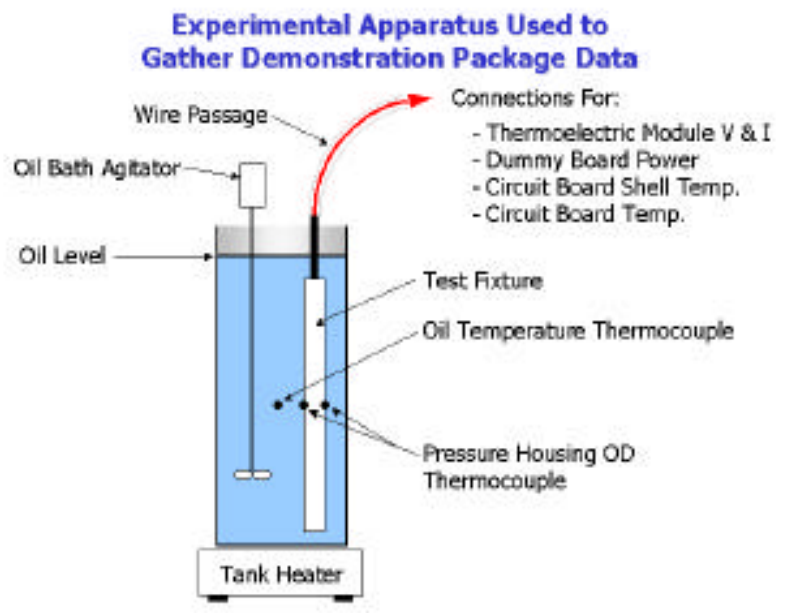

Figure 4. TEC Test Setup 
the test set-up employed by APS; Figure $\mathbf{5}$ summarizes temperatures during the test.

Thermoelectric coolers (TEC) were used to remove heat from within a pressure barrel containing the dummy MWD board. Temperature and power data were recorded as the assembly was operated in an oil bath. The oil bath represented fluids in a hot well just as the dummy board represented the heat generated by MWD components. The data show that TECs can reduce the temperature inside the pressure barrel and on the circuit boards to acceptable levels. Table 2 summarizes the test data. The temperature of the oil bath was manually controlled and held at $200^{\circ} \mathrm{C}$ while temperatures where measured at two locations on the housing $180^{\circ}$ apart at the inside surface of the pressure housing at the TEC and on the dummy board. Power to the TEC was monitored, as was power to the dummy board. The

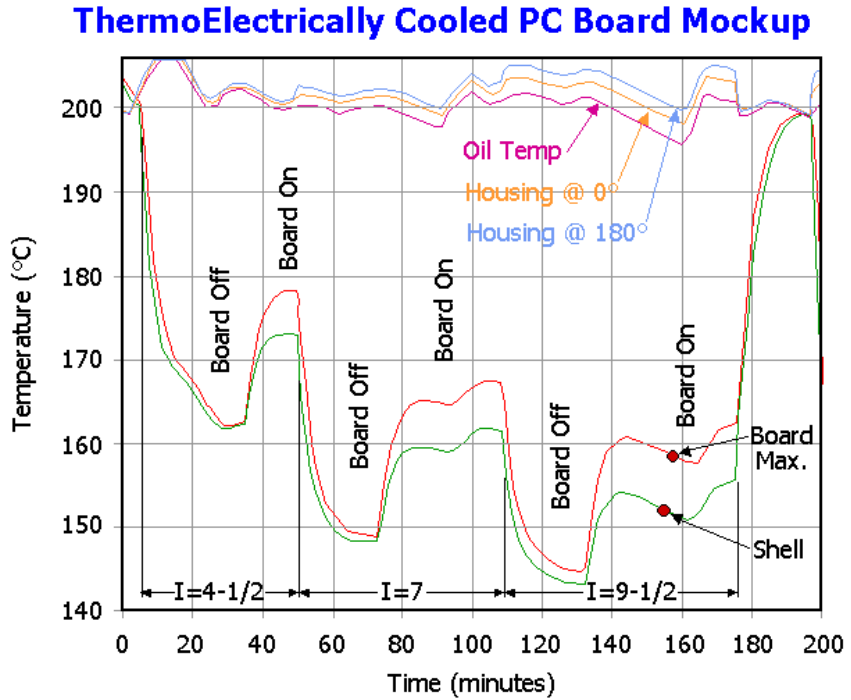

Figure 5. Thermoelectric Cooling Tests heat that leaks into the pressure barrel is estimated from the analytical model, and the efficiency of the thermoelectric device (ratio of heat pumped to thermoelectric power consumed - COP) calculated. The data show that the thermal model effectively represented the test. Results indicated that the TEC can reduce the board temperature from 40 to $54^{\circ} \mathrm{C}$ below ambient temperature. Since this is a sufficient reduction to keep the board cool in wells that are $195^{\circ} \mathrm{C}$, it was found that a TEC is a possible solution.

Table 2. Thermoelectric Cooling Test Data

\begin{tabular}{|c|c|c|c|c|c|c|c|c|c|c|c|c|c|c|}
\hline \multirow{2}{*}{$\begin{array}{l}\text { Time } \\
(\mathrm{min})\end{array}$} & \multicolumn{7}{|c|}{ Temperatures } & \multicolumn{3}{|c|}{ Thermoelectric Coolers } & \multicolumn{3}{|c|}{ Power } & \multirow[b]{2}{*}{$\mathrm{COP}$} \\
\hline & Oil & $\begin{array}{l}\text { Housing } \\
\text { @TEC }\end{array}$ & $\begin{array}{l}\text { Housing } \\
@ 180^{\circ}\end{array}$ & Shell & $\begin{array}{l}\text { Board } \\
\text { Max. }\end{array}$ & $\begin{array}{l}\text { Board } \\
\text { Avg }\end{array}$ & $\begin{array}{l}\text { ÄT } \\
\text { TEC }\end{array}$ & Amps & Volts & Watts & Board & Leak & Total & \\
\hline 4 & 202.4 & 203.1 & 202.9 & 162.3 & 162.5 & 162.4 & 40.8 & 4.5 & 8.25 & 37.125 & 0 & 21.4 & 21.4 & 0.58 \\
\hline 48 & 200.0 & 201.1 & 200.6 & 173.0 & 178.3 & 175.7 & 28.1 & 4.5 & 9.52 & 42.84 & 15 & 14.7 & 29.7 & 0.69 \\
\hline 72 & 200.5 & 202.3 & 201.5 & 148.3 & 148.8 & 148.5 & 53.9 & 7 & 14.26 & 99.82 & 0 & 28.3 & 28.3 & 0.28 \\
\hline 105 & 200.5 & 202.6 & 201.8 & 161.9 & 167.6 & 164.7 & 40.7 & 7 & 14.06 & 98.42 & 15 & 21.4 & 36.4 & 0.37 \\
\hline 131 & 201.3 & 204.6 & 203.2 & 143.2 & 144.5 & 143.8 & 61.4 & 9.5 & 18.96 & 180.12 & 0 & 32.2 & 32.2 & 0.18 \\
\hline 173 & 200.8 & 204.9 & 203.2 & 155.2 & 162.0 & 158.6 & 49.7 & 9.5 & 18.78 & 178.41 & 15 & 26.1 & 41.1 & 0.23 \\
\hline
\end{tabular}

The test data also show that a TEC would consume considerable electrical power, thus requiring the use of a turbine generator. Power would then only be available when the pumps were operating, so a Dewar-type pressure housing would be 
needed to insulate the MWD electronics and keep them at rated temperatures for acceptable periods of time while the pumps were off. Both the generator and housing increase the cost of this system. In addition, to achieve higher efficiency, the inside of the Dewar would need to be filled with a dielectric fluid. This makes assembly more difficult since the normal potting medium is not a good heat conductor and space would need to be provided for the dielectric when potting the system.

Despite these drawbacks, a cooling system should be considered in the future for high-temperature MWD systems. The market size for these systems will likely remain small and the potential for development of new high-temperature components is not well defined. Both of these factors will dictate whether cooling is a more economical approach.

\section{Task 3. Design of a High-Temperature Gamma-Ray Detector}

Many MWD suppliers, including Halliburton, normally use solid-state gamma detectors. Unfortunately, these devices cannot be used at high temperatures because materials used in their construction will break down. The best way to measure gamma radiation at higher temperatures is with Geiger Muller tubes. One advantage to the Halliburton/Sperry Sun merger was that Sperry Sun already had a gamma detector based on Geiger Muller tubes. Halliburton had received designs from two different companies, but neither of these systems was constructed before the merger. CBG group in Austin, Texas, was one of the companies that quoted on the construction of a Geiger Muller-based gamma detector. Halliburton was preparing to release a purchase order at the time of the merger. Instead, Sperry Sun later performed HALT to determine changes needed to upgrade their Geiger Muller unit to $195^{\circ} \mathrm{C}$. Testing highlighted problems in the unit's electronics which were modified and repaired successfully.

Task 4. Selection of High-Temperature Components for Use in MWD/Gamma Tool

Both Halliburton and Sperry Sun used HALT to identify components or batches of components that performed adequately at high temperatures. Halliburton sought to develop new components and designs while Sperry Sun identified areas that could not be addressed through the batch process and redesigned the circuits to eliminate these components.

Halliburton had selected many different high-temperature elements before the project was temporarily halted (due to the merger). The processor and memory selected would likely have been the ELCON hybrid chip set. High-temperature passive components such as resistors and capacitors had been purchased. In addition, board, solder, and potting materials for the $195^{\circ} \mathrm{C}$ tool had all be selected.

Halliburton had made progress on developing high-temperature magnetometers and accelerometers. ATEC agreed to manufacture high-temperature magnetometers at no cost in return for test data from the project. Japan Aviation Electronics in Tokyo completed tests on accelerometers and it appeared that they had solved problems with long-term drift. Halliburton had also located a radiation-hardened hex buffer IC that was test to $250^{\circ} \mathrm{C}$ (the limit of their oven). 
Halliburton ran HALT on the TCM (telemetry communications module), which developed failures at 160 to $165^{\circ} \mathrm{C}$ due to E-prom read or write errors. This problem had been anticipated and would have been solved by using flash memory in place of the E-prom.

Halliburton, working with Battery Engineering Inc. of Hyde Park, Massachusetts, had developed a lithium-magnesium battery that would operate in the temperature range of $125-214^{\circ} \mathrm{C}$. Lithium thionyl chloride batteries are normally used to provide power for MWD tools. Unfortunately, lithium has a melting point of $180^{\circ} \mathrm{C}$, and standard lithium batteries are normally limited to operating temperatures of $160^{\circ} \mathrm{C}$ and below. If magnesium is alloyed with the lithium anode, operating temperature can be increased, although with a reduction in current capacity (Table 3).

Table 3. Temperature Performance of Li-Mg Batteries (DD size)

\begin{tabular}{|l|c|c|c|c|}
\hline Anode Type & \% Magnesium & $\begin{array}{c}\text { Melting Point } \\
\left({ }^{\circ} \mathrm{C}\right)\end{array}$ & $\begin{array}{c}\text { Max Oper Temp } \\
\left({ }^{\circ} \mathrm{C}\right)\end{array}$ & $\begin{array}{c}\text { Current Capacity } \\
(\mathrm{A}-\mathrm{hr})\end{array}$ \\
\hline Lithium & 0 & 180 & 160 & 26 \\
\hline Li-Mg & 10 & 202 & 180 & 20 \\
\hline Li-Mg & 25 & 220 & 200 & 15 \\
\hline
\end{tabular}

Battery Engineering developed high-temperature batteries based on the lithium/magnesium alloy. A size DD battery with $25 \%$ magnesium can be safely used to $200^{\circ} \mathrm{C}$ (as required for this MWD development). Current capacity, while reduced to 15 A-hr, is sufficient for at least 250 circulating hours downhole. The primary disadvantage of this recipe is that power output below $100^{\circ} \mathrm{C}$ is poor.

At the time the project was paused due to the merger, discussions were taking place to decide if heaters would be used to maintain the temperature of the lithium/magnesium batteries at minimum operational levels, or if a sacrificial nickelcadmium battery pack would be used to power the tool at lower temperatures. For the approach incorporating a sacrificial battery, a low-temperature battery pack would shut down and the high-temperature batteries come on-line as the tool's temperature rose above $125^{\circ} \mathrm{C}$. The low-temperature batteries would be replaced after each run.

Sperry Sun had difficulty in proving two directional packages (magnetometers and accelerometers) for the test. These were the last individual components proven. One was from Sperry Sun's internal research department in Cheltenham, England and the other from Tensor in Austin, Texas. Work with Tensor began under Halliburton, but no contract was ever placed. Tensor had indicated that they could build the $195^{\circ} \mathrm{C}$ directional package, but never provided a quote to Halliburton. Only one of three units supplied to Sperry Sun was found to qualify at higher temperatures. This area remains as a key item requiring additional work.

The problem components identified by Halliburton for the directional package (magnetometers and accelerometers) were never tested because they dd not fit the 
form that Sperry Sun needed. However, the manufacturers felt confident they had succeeded in developing high-temperature components.

Task 5. Design High-Temperature MWD/Gamma Tool

Both Halliburton and Sperry Sun took advantage of the opportunity presented by the project to make changes in the design of their MWD tools. Sperry Sun enhanced many areas of their tool (Table 1 presents a list of major changes that were made and incorporated into their current line of tools). Halliburton was just beginning this task when the merger took place; however, through HALT testing they had identified many changes that would be required to meet the temperature goals.

Task 6. System Fabrication

Halliburton did not have the opportunity to advance as far as system fabrication. Sperry Sun was, in one sense, working on fabrication throughout Tasks 4 and 5 since they used their current system as a base and were only modifying and substituting parts that qualified for higher-temperature service for existing parts. Figure 6 shows the Sperry Sun tool being loaded into an oven for a high-temperature proof test. Figure 7 shows the temperature controller during the test. The temperature is $193^{\circ} \mathrm{C}$ with a set point of $195^{\circ} \mathrm{C}$. Both tools were tested and proven in this oven before field testing.

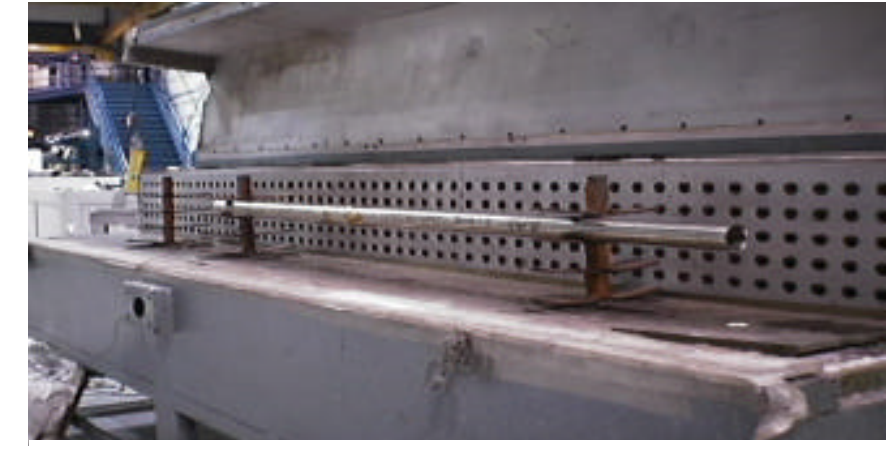

Figure 6. Sperry Sun MWD Tool Being Prepared for Oven Test

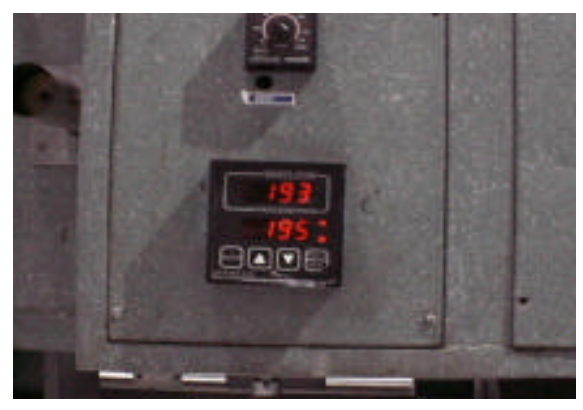

Figure 7. Oven Controllers

\section{Task 7. Laboratory Testing}

The Sperry Sun tool was under constant laboratory testing during the proofing process. Task 7 was originally conceived for the Halliburton MWD tool since it was basically a new tool (in contrast to Sperry Sun's tool, which had already undergone significant development and testing).

\section{Task 8. Low-Temperature Field Test}

A field test was conducted with the two Sperry Sun MWD tools prepared under this project. Originally, this test was to be a shake-out of a new Halliburton tool and therefore was to be conducted at lower temperatures so that problems not related to temperature could be identified. Since the Sperry Sun tool was much closer to a conventional (market-ready) tool, the first test was conducted at elevated temperatures $\left(180^{\circ} \mathrm{C}\right)$. While not the tool's limit, this temperature range still represented an ambitious test. (See next section for details on field testing.) 


\section{Field Test}

A field test of two 195C MWD tools was conducted in Lavaca County, Texas (Figure 8). Sperry Sun's field report is presented in Appendix A. The purpose of this operation was to provide directional services on a sidetrack of a straight hole. The sidetrack was to intersect the formation up-dip above the water/gas interface. In addition, the gamma tool provided formation data including seam tops and thickness.

Conventional Solar 175 tools were used in the beginning of the operation. The well temperature at $16,500 \mathrm{ft}$ was $160^{\circ} \mathrm{C}$. The prototype $195^{\circ} \mathrm{C}$ tools were then run instead of the standard Solar 175 tools. The first prototype tool went below the rotary table on August 1, 2001 at 17:30 hours (Figure 9). Thirty minutes later, a shallow test was conducted to check for proper operation. At 11:45 hours on August 2, 2001,

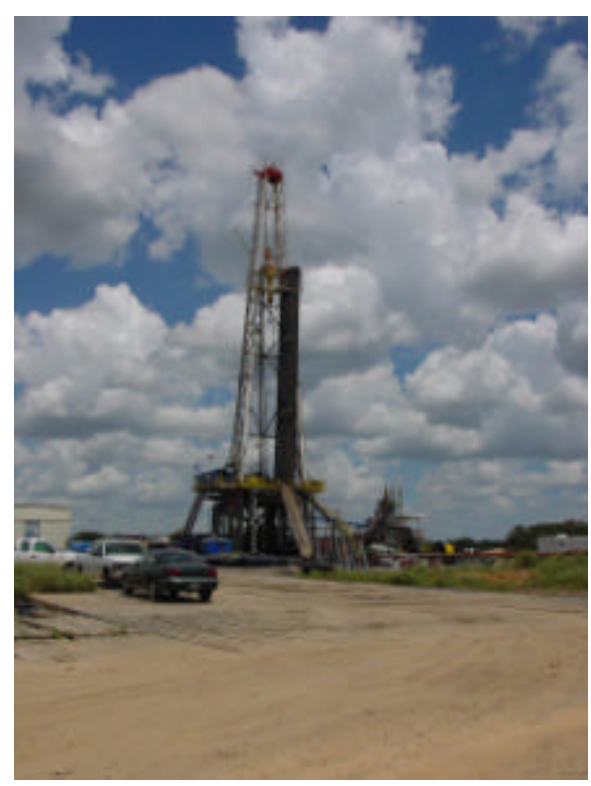

Figure 8. Rig Site the tool reached bottom and drilling was begun. (The long trip time is the result of a rig shut-down for BOP repair.) The first recorded temperature was $178^{\circ} \mathrm{C}$. The tool stopped pulsing on August 4, 2001 at 23:00 hours, after operating on bottom for 59 hours. Data downloaded at the surface at the end of the test showed that the tool continued to record data until 1:44 hours on August 5, 2001 - an additional 27 hours. The tool was pulled from the well at 2:30 hours on August 6, 2001. Total downhole hours (from the time the tool moves below the rotary table until it is returned to the surface or fails down hole) was 115 hours.

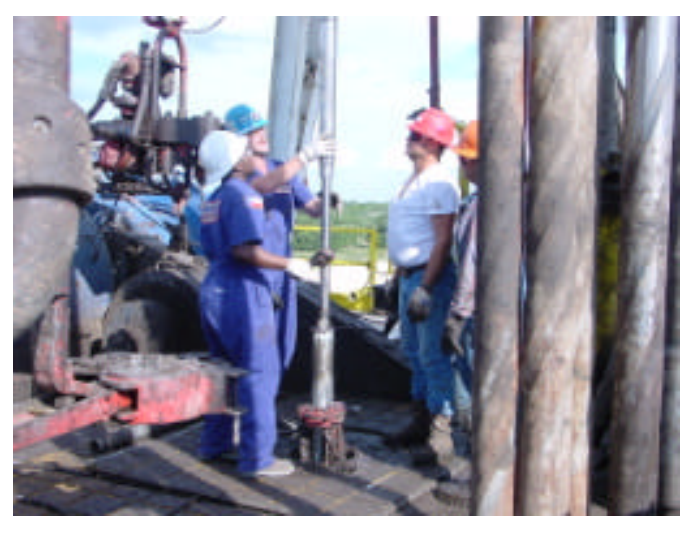

Figure 9. Tool Preparation

The second prototype tool was run into the well at 3:30 hours on August 6, 2001. Gamma logging of a missed interval from the previous run was begun at 18:30 hours the same day. At 22:00 the tool was on bottom drilling. At 5:30 hours on August 7, 2001 the tool stopped pulsing. The highest temperature recorded was $187.2^{\circ} \mathrm{C}$. Drilling continued blind and the tool was pulled from the well on August 13, 2001 at 22:00 hours. Total time below the rotary table was 186.5 hours. Total time before data transmission was lost was 26 hours.

Each of the tools was given a post-mortem examination. The first tool was found to have a failed pulser. Drilling fluid had entered the tool past the poppet seals. The poppet bearings also showed unusual wear. Although the barite content of the field mud was high, the amount of wear on the bearing was unexpected. A typical tolerance for this bearing is 0.003 inches. The 
bearing in the first tool was found to have a clearance of 0.015 inches. This allowed the poppet to move laterally and damage the seal, ultimately leading to the failure of the pulser. Data from the tool's telemetry module were successfully downloaded after the operation, demonstrating that the electronics had not failed during this run. Battery voltage was very low (which could have been caused by exposure to high temperatures). The special high-temperature batteries do not begin functioning at full voltage until they reach $125^{\circ} \mathrm{C}$.

On the second tool, the pulser was also found to have failed. However, a bearing that had been inadvertently left out during assembly caused the premature failure. It was also found that the back-up battery in the telemetry module had vented, which damaged wiring and electronic components. After the battery was removed, attempts to unload memory were unsuccessful due to damage from the battery fluid. Data from this run were determined to be lost. It was not apparent why the battery had vented. Heat could have been a factor, although these batteries should have been capable of operations up to $214^{\circ} \mathrm{C}$.

Results from these field tests indicate some progress in the development of a $195^{\circ} \mathrm{C}$ tool. Failure of the pulsers appears to have been from mechanical rather than electrical causes. The vented battery may indicate that more work is needed in this area, but only further field tests would conclusively highlight the weakness(es). It was particularly unfortunate that the second tool was improperly assembled. Even with a vented battery, data collected from the run would have helped determine how the electronics were performing under elevated temperatures.

\section{Economic Analysis}

Analysis of the economics of the $195^{\circ} \mathrm{C}$ tool highlights the greatest obstacle to future commercialization. Costs to screen individual components, then subassemblies, and finally completed tools for high-temperature operations are very high. Tests to date also show a relatively short life for high-temperature tools - on the order of 300 hours (as compared to approximately 1000 hours for a commercial MWD tool operating at temperatures up to $150^{\circ} \mathrm{C}$ ). These factors mean that the daily cost of the tool will be much higher than a conventional tool. In addition, high-temperature MWD tools are difficult to prepare. For these development efforts, the engineering department made use of highly trained technicians and engineers to prepare these tools. While the normal production staff is well qualified to manufacture tools for conventional applications, it would be difficult for them to prepare, trouble-shoot, and maintain the $195^{\circ} \mathrm{C}$ tools on a continuing basis.

Table 4 summarizes costs for the extra labor required to produce $195^{\circ} \mathrm{C}$ tools. These data are then used to calculate a daily cost for the tool. Daily costs are based on an operating life of 300 hours, which was determined from the laboratory testing of the $195^{\circ} \mathrm{C}$ tools. Table 4 shows additional screening costs to run HALT on components to find those that will function at $195^{\circ} \mathrm{C}$. 
Table 4. Screening Costs for Higher Temperature Components

\begin{tabular}{|l|c|c|c|}
\hline Tool Module & Standard Cost & $\begin{array}{c}\text { Additional } \\
\text { Screening Cost }\end{array}$ & Total Cost \\
\hline Pulser & - & - & - \\
\hline TM & - & - & - \\
\hline DM & - & - & - \\
\hline GM & - & - & - \\
\hline BM & - & - & - \\
\hline Expendables (flow gear, interconnects) & - & - & - \\
\hline TOTAL & $\$ 129,062$ & $\$ 48,000$ & $\$ 177,062$ \\
\hline
\end{tabular}

Table 5 shows the recovered costs after a field run. This is calculated by subtracting the standard (expected) repair costs from the new equipment cost. The cost of a nonmagnetic drill collar to house the tool is approximately $\$ 30,000$.

Table 5. Recovered Costs

\begin{tabular}{|l|c|c|c|}
\hline Tool Module & Standard Cost & Repair Costs & Total Recovered Costs \\
\hline Pulser & - & - & $\$ 6,927$ \\
\hline TM & - & - & $\$ 1,300$ \\
\hline DM & - & - & $\$ 2,426$ \\
\hline GM & - & - & $\$ 2,426$ \\
\hline BM & - & - & $\$ 2,426$ \\
\hline Total & $\$ 119,753$ & $\$ 104,248$ & $\$ 15,505$ \\
\hline
\end{tabular}

The total cost to operate the tool, excluding manpower, will be the cost of a standard tool plus the cost for additional screening minus the recoverable costs or;

$$
\text { Operating Cost }=\$ 129,062+\$ 48,000-\$ 15,505=\$ 161,557
$$

The operating time of 300 hours is equivalent to 12 days; thus, the day rate will be $\$ 13,463$. This cost does not include the cost of capital to build the tools or the cost associated with the loss of technical personnel's time when they are needed to keep these tools operating.

Other costs include depreciation (\$282/day) and crew charges (estimated at $\$ 1000 /$ day). The total estimated daily cost for the new tool is $\$ 14,745 /$ day. This cost compares to $\$ 3,000$ to $\$ 4,000 /$ day for a Solar 175 . Thus, the cost of the $195^{\circ} \mathrm{C}$ tool is 3 to 5 times more than a conventional tool. It is unlikely that many operators will be willing to pay this price, making the $195^{\circ} \mathrm{C}$ tool uneconomical to offer commercially.

These estimates are based on an operating life of 300 hours, high costs of screening parts, and a highly technical labor force needed to maintain the prototype 
tools. It is difficult to determine whether operational experience could increase operational life and reduce manufacturing and maintenance costs, and thereby reduce the daily rate. Currently, Sperry Sun does not foresee sufficient market size to justify the expense to estimate these parameters. However, it is clear that new gas discoveries will be from increasingly deeper and hotter wells, and that the DOE should aid in the development of tools for these applications. It is also clear that an important area for additional work is to determine what is possible in reducing the costs and extending the life of the $195^{\circ} \mathrm{C}$ tools.

\section{Benefits to the MWD Industry} following areas:

Sperry Sun and the MWD industry have benefited from this program in the

Pulser Improvements. Several improvements were implemented in "O" ring selection, oil selection, and other areas. Many improvements were made to the positive pulser as a result of the $175^{\circ} \mathrm{C}$ programs, which had taken place before this contract was started with Sperry Sun. Based on project tests, relatively few components of the system needed to be upgraded.

Magnetometer and Calibration Improvements. Work on the magnetometer included upgrades to Sperry Sun (i.e., Tewkesbury) magnetometers in response to higher temperature requirements. This has led to improvements to the design of Sperry Sun's existing magnetometers as used in the Tewkesbury tool family, which will be beneficial across all directional work. Further work was done with Tensor (then Honeywell) in Austin to obtain high temperature. This work showed clearly some of the limitations in the screening strategy Sperry Sun was following. Tensor has included a redesign of the magnetometers with some hightemperature electronics. It proved very difficult to get magnetometers built that perform consistently. This work in turn revealed deficiencies in the modeling methods used to correct errors introduced by temperature. Required modifications to address these findings are still ongoing within Sperry Sun. They are re-evaluating calibration methods for all of our directional tools used in the USA and internationally.

Software Improvements, Resetting and Power-Up Problems. It was discovered as part of this effort hat the processor Sperry Sun was using has anomalous behavior when being reset at high temperatures. This required software changes to be made both in the downhole code and tool programming code. The changes that were required provided another opportunity to improve the robustness of the downhole tool string. This is one of the indicators that translating the processor to a high-temperature semiconductor would be very beneficial in producing a new range of high-temperature tools.

Identification of Circuit Design Weaknesses. As the process of screening MWD components for higher and higher temperatures was conducted, unexpected problems were observed, including voltage reference drift problems 
and capacitor failures. Voltage reference drift proved difficult to solve because of its impact on the power supply. (This is another candidate for high-temperature semiconductor technology.) The capacitor issue identified a failure in the QC process of production and led to a re-evaluation of tantalum capacitors and testing under high-stress conditions. This work was undertaken independently (not as part of this contract) with a company, which Sperry Sun subcontracted to investigate this issue. A further conclusion regarding capacitor problems is that only improving the silicon is not enough. To make high-temperature tools, we need to develop designs which eliminate the need for these types of capacitors or work with manufacturers to build very high-temperature (high-capacitance) capacitors. Sperry Sun believes the temperature range of some low $(<100,000$ pF) capacitor technologies can be extended; however, they are less certain that it will be possible to economically extend high value technologies.

The project has helped in clearly demonstrating the limitations of the methods Sperry Sun is currently using to produce high-temperature tools. Based on this work, they are considering the available high-temperature technologies and looking at approaches for introducing these technologies over the longer term.

\section{Conclusions and Recommendations}

1. Results of this development effort showed that, while it is possible to build a mud-pulse MWD tool that can operate at $195^{\circ} \mathrm{C}$, performance of the current tool is probably not sufficient for commercial success. The current temperature limit of $175^{\circ} \mathrm{C}$ is apparently the practical limit for conventional electronics. This conclusion is further supported by Sperry Sun's decision to market two tools, one for service up to $150^{\circ} \mathrm{C}$ and another (the Solar 175) tool for service from 150 to $175^{\circ} \mathrm{C}$. This decision was made based on the additional costs to screen components for the Solar tools, which make if more difficult to compete with lower temperature tools from other manufacturers. Currently, the bulk of commercial MWD work is at temperatures below $150^{\circ} \mathrm{C}$.

2. Industry's current R\&D goals and perception of future MWD requirements do not focus on operations in hotter and deeper formations. Sperry Sun (for example) is pursuing the larger segment of the market (operations at less than $150^{\circ} \mathrm{C}$ ). Their corporate vision is not in strict agreement with the DOE's vision that future gas needs for the USA will be met with gas produced from deeper, hotter reservoirs. However, businesses almost always trend toward the highvolume sector(s) of business. This apparent difference in vision may indicate that the service industry does not currently recognize what the future needs will be. The DOE can help bridge this gap in perception by presenting data that demonstrate how much gas is located in high-temperature reservoirs. If this information describing future markets is not readily available, the DOE could fund a study to highlight the quantity and location of current and future hightemperature reserves. These data may then serve to encourage the MWD industry to place resources into development of tools for high-temperature operations. 
3. Due to the extensive testing required and the high percentage of failing components, use of a binning qualification process to build hightemperature $\left(195^{\circ} \mathrm{C}\right) \mathrm{MWD}$ tools is very costly. Costs to screen individual components, then subassemblies, and finally completed tools for hightemperature operations are very high. Tests also show a relatively short life for high-temperature tools. These factors mean that the daily cost of an MWD tool developed through binning processes will be much higher than a conventional tool.

4. Increasing the operating temperature of current MWD tools will require development of a new platform for the electronics used in these tools. This technology already exists in a limited number of components, and has been used to develop some special geothermal tools. Sandia National Laboratory has taken the lead role in this area and is developing or interested in the development of tools based on silicon-on-insulator (SOI) technology to overcome high geothermal temperatures. Oilfield MWD could make use of SOI technology to develop the next generation of tools that could allow raising the current temperature limit $\left(175^{\circ} \mathrm{C}\right)$ not marginally (as seems to be the limit with conventional electronics), but to as high as $300^{\circ} \mathrm{C}$.

5. There are several hindrances to the development of silicon-on-insulator (SOI) tools for the MWD industry. First is the size of the task at hand. Since this represents a new platform, programming would have to be extensively modified. Sperry Sun and MTI estimate that this is at least a 2-man-year effort. This does not include testing and debugging after programming. Completely new circuits would have to be developed to use the SOl chips now available. In addition, some components still need to be improved for high-temperature use including magnetometers and accelerometers needed for determining direction and trajectory of the well. This project has advanced the development of these components, but more work is needed, including examining other nonconventional technologies to measure primary MWD parameters, angle, and direction. Perhaps one of the most challenging obstacles to the development of the next generation of MWD tools is the (understandable) reluctance of service companies to make obsolete their current inventories of tools.

6. DOE leadership and partership with industry can play a significant role in encouraging the development of high-temperature MWD tools to prepare for the future. If the DOE's prediction of future requirements for higher and higher temperatures is correct, then the oil and gas industries could find themselves without proper means to exploit reserves to meet the nation's demand. This could have a significant impact on the US economy. The price of oil and gas is very volatile, and an inability to meet demand can result in rapid price increases. If reserves from hotter reservoirs were soon needed, it could require 2-3 years to develop the tools to efficiently recover them. During this period, prices would continue to rise, increasing the cost of US products and the costs to maintain the current standard of living. The DOE can encourage industry to develop critical components needed to construct new high- 
temperature platforms. Providing funding will help reduce the risk and offset the loss for obsolescence of current inventories. Critical components include the magnetometer and accelerometers, as well as the new circuits that implement SOI technology. The final critical area for DOE assistance is in programming required for the new platform. MTI and Sperry Sun believe that the best area to start this work is to develop the primary processor chip using SOI technology. It may be possible to build the current processor using this method, which could reduce reprogramming time. Development of high-temperature directional packages is equally important since these are common to all MWD tools. 
Appendix A

Field Test Report 


\title{
ธอยอาㄱาy-ธபา \\ DRILᄂING SERUICES
}

a Halliburton company

\section{Technical Services \\ Job Number: HD-MJ-10113}

\section{Solar 195}

\author{
Lavaca Co., Texas \\ $<1$ Aug to 14 Aug 2001>
}

Tech Services Engineers: Harvey Mueller 


\section{Contents}

Objectives

Section 1

Purpose

Goals

Test Plan

NEPA Information

Summary and Post Run Evaluation Section 2

Recommendations Section 3

Job Report Section 4

LWD Logs Section 5

Mud Reports Section 6

Digital Data Section 7

Miscellaneous Section 8 


\section{Objectives}

\section{- Purpose of Job}

This well was a sidetrack to the original straight hole. The target zone produced only water. The well was sidetracked to intersect the target payzone updip and above gas/water contact. The open hole sidetrack was done using Solar 175 directional tools. Directional tools were run to maintain directional control of the wellpath and the Natural Gamma Ray logging tool was included to correlate with offset wells, determine formation tops and payzone thickness.

- Goals

The development Solar 195 tools were run in this well to test the operation and survivability of these tools. Anticipated BHT was expected to be $360^{\circ} \mathrm{F}$ at a depth of $18400 \mathrm{ft}$. using $18.5 \#$ oil base mud. This would test of the operational capabilities of these tools.

- Test Plan

BHT was $321^{\circ} \mathrm{F}$ at a depth of 16500 toward the end of run 400 using Solar 175 tools. The Solar 195 tools were run on the following and all subsequent runs. The Solar 195 tools are a drop in replacement and will provide surveys and Gamma data.

\section{- NEPA Information}

4. Project/Activity Description: The proposed action involves field testing a rew drilling services system, specifically a Solar 195 Directional Gamma MWD tool, in order to assess the system's performance level. DOE's contractor is responsible for identifying field test opportunities, i.e., a well, and arranging all logistics with the operator (owner) of the well to conduct the drilling system performance test. A wellbore or section of wellbore will be drilled with the motor/bit combination for an appropriately permitted well.

Drill cuttings (sandstone, shale, \& limestone fragments) will be generated during operation/testing of the product. These cuttings, however, are not incremental waste. The cuttings will be generated by the well owner's own actions (drilling operations), whether testing of the DOE-sponsored product(s) occurs or not. The well operator/owner is responsible for proper treatment and disposition of the cuttings.

The DOE-sponsored drilling product will be "on location" (at the wellsite) for varying lengths of time. It is anticipated that the drilling system will be on location for about 1 weeks, beginning on or about 24 Jul 2001. 
5. Brief Description of Affected Environment: Field performance testing of the drilling system will occur in an appropriately permitted well. Testing of the motor/bits will take place in the John W. Hancock, Sr A-1 ST, a new well, located $29^{\circ} 18^{\prime} \mathrm{N}$ Latitude and $96^{\circ} 38^{\prime} \mathrm{W}$ Longitude. The well is owned/operated by Louis Dreyfus Natural Gas and will be located $10 \mathrm{mi}$ SE of Hallettsville, TX. The surface environment in the immediate vicinity is gently rolling grassland associated with local farms and ranches.

The affected environment will be primarily below ground level (subsurface, as a well is being drilled). The drilling, using the Solar 195 Directional Gamma MWD tool, will take place in an appropriately permitted well, thus all penetrated strata will be treated in an approved manner, e.g., aquifers isolated, etc. 


\section{Summary}

\section{Run 500 Timeline}

01 Aug 17:30 Below rotary

01 Aug 18:00 Shallow test

02 Aug 11:45 On bottom and start drilling; First recorded temperature- $353^{\circ} \mathrm{F}$

04 Aug 23:00 Tool quit pulsing; Drill ahead blind

05 Aug 01:44 Last good data point in Gamma memory; After this point all Bank A, B and C were filled with 7590 or 7650 .

05 Aug 01:54 Gap in gamma data 01:54:42 to 01:58:41

05 Aug 10:16 Gap in gamma data from 10:16:13 to 12:49:49

05 Aug 15:13 Gap in gamma data from 15:13:11 to 06 Aug 02:57:02

06 Aug 02:30 End of run

\section{Run 500 Post Run Evaluation}

\section{Mk 8 Pulser 8176}

Incoming:

Passed resistance test but failed poppet extension and bench test. No signs of mud leaking out of the tool.

Tear down:

The pulser was full of drilling fluids. The origin of the drill fluid intrusion was the seal pack and the oring seal on the poppet shaft. The o-rings in the seal pack was nibbled. Where the poppet shaft rides on the seal pack the shaft showed some pitting on it. The o-ring on the poppet shaft was extruded and blown inward into the pulser. All the case seal o-rings looked good. The o-rings on the kemlon feedthru's were still sealing but showed some sign's of extrusion. The intermediate case was checked and it had no cracks.

Over view:

The upper bearing was also very worn. The upper bearing in this pulser measured .4491 . The old bearing was worn out so far it couldn't be pressed out. A new bearing in the end plug measured .4341 This leaves a gap of .015. This upper bearing ring ID has an extreme amount of wear. We control the ID to within a 
$.0003 "$ tolerance. It wore $.015 "$ oversized diametral in a relatively short amount of time. The wear would have allowed for more and more lateral deflection of the poppet.

A new end plug assembly was picked out at random and was measured.

New housing $\quad=.5650$

New bearing O.D. $\quad=.5675$

New bearing I.D. $\quad=.4353$

New bearing I.D. installed $=.4341$

Poppet shaft O.D. $\quad=.4341$

\section{BM 146746}

Incoming:

Downloaded memory data successfully using INSITE. Manually enabled sub bus power from the batteries. Sub bus power was $\sim 10 \mathrm{~V}$. and would fail once CIM I/O card power was removed from the SBM. It appears the batteries were depleted, perhaps due to the short in the end plug.

Tear down:

Tested the SBM electronics at $195^{\circ} \mathrm{C}$. The board is still working as it is supposed to. It is measuring the battery voltages, currents, and temperature correctly. The battery over-current protection is also still functioning as specified.

The cells do appear to be near dead from room temperature evaluation. In the next 2 weeks I plan on getting the cells heated up and tested again at or above $125^{\circ} \mathrm{C}$. Their present poor performance could be due to the cold room temperature.

Overview:

\section{Run 600 Timeline}

06 Aug 03:30 Below Rotary

06 Aug 18:30 Begin reaming to log Gamma over section lost when tool failed on previous run

06 Aug 22:00 On bottom; begin drilling

06 Aug 05:30 Tool quit pulsing; Drill ahead blind.

13 Aug 22:00 End of run 


\section{Run 600 Post Run Evaluation}

\section{Mk 8 Pulser 8178}

Incoming:

Passed resistance test but failed poppet extension and bench test. The poppet cap was broken.

Tear down:

The pulser was full of drilling fluids. The origin of the drill fluid intrusion was the seal pack and the oring seal on the poppet shaft. The poppet shaft had two groves in it where it was hitting the end cap. There was no upper bearing in the end cap. This caused premature failure in the bootless top end and the breaking of the poppet cap. All the case seal o-rings looked good. The o-rings on the kemlon feedthru's were still sealing but showed some sign's of extrusion.

The intermediate case was checked and it had no cracks.

Over view:

The upper bearing was not installed and caused the failure of the pulser.

\section{TM 146620}

Incoming:

We were unable to communicate with the TM.

Tear down:

Upon pulling the electronics from the case it was found that the backup battery had vented which damaged the wiring to the electronics package. The backup battery was removed and we attempted to communicate with the electronics but were unable to as the vented cell damaged the boards.

Overview:

The backup battery caused the failure on the TM. It has not yet been determined what caused the backup battery to vent.

BM 146747 


\section{Recommendations}




\section{Job Report}

- End of Well Report 


\section{End of Well Report for Louis Dreyfus Natural Gas}

Rig: $\quad$ H \& P 89

Well: John W. Hancock Sr. \#A-1 ST

Field: Wildcat

Country: U.S.A.

Job No: HD-MJ-10113

Date: $\quad 08-J u l-01$

API No: $\quad 42-285-32871-01$ 


\section{Table of Contents}

1. General Information

2. Operational Overview

3. Summary of MWD Runs

4. Bitrun Summary

5. Directional Survey Data

6. Service Interrupt Report 


\section{General Information}

Company:

Rig:

Well:

Field:

Country:

API Number:

Sperry-Sun Job Number:

Job start date:

Job end date:

North reference:

Declination:

Dip angle:

Total magnetic field:

Date of magnetic data:

Wellhead coordinates N:

Wellhead coordinates $\mathrm{E}$ :

Vertical section direction:

MWD Engineers:
Louis Dreyfus Natural Gas

H \& P 89

John W. Hancock Sr. \#A-1 ST

Wildcat

U.S.A.

42-285-32871-01

HD-MJ-10113

08-Jul-01

09-Aug-01

Grid

5.138

deg

58.842

48529.223

deg

01-Jan-70

29 deg. 18 min $1.640 \mathrm{sec}$ North

96 deg. 38 min $34.350 \mathrm{sec}$ West

122.526 deg
K. McCoy
T. Bufford
L. Motl

Company Representatives:

D. Patton

R. Coates

Company Geologist:

Lease Name:

John W. Hancock Sr.

Unit Number:

State:

Texas

County:

Lavaca 


\section{Operational Overview}

Sperry-Sun Drilling Services was contracted to provide Solar 175 MWD and directional drilling services for sidetracking the John W. Hancock Sr. A-1 well. MWD services began 08-Jul-01. The sidetrack was completed 12-Aug at a measured depth of 17777. Run 100 was a directional only run to open hole sidetrack the well at 14153' MD. The run started 09-Jul and was completed at 14212' MD 12-Jul after 50 circulating hours. MWD tool RPM's dropped from 3200 to 2200 during the run, but caused no problems during the run. Post-run inspection revealed damaged marine bearings. Run 200 directional / gamma run began 12-Jul and was completed at 15094' MD after 136 circulating hours. MWD tool RPM's caused the intermittent pulsing during the run and ranged from 3200 at run start to 1200 at end of run. Pulser failed post-run poppet extension test. Run 300 began 19-Jul and was completed 20-Jul after MWD quit pulsing after 16.5 circulating hours. Tool sent to R \& $M$ for testing. Run 400 began 21-Jul and was completed 31 -Jul after 213 circulating hours. MWD setup was changed to compensate for RPM loss during run. Tool RPM's ran from 3900 at start of run to 2200 at end of run. Post run inspection revealed damaged marine bearings. Maximum temperature during run was $332^{\circ} \mathrm{F}$. Pulser failed post-run retraction test. Run 500 was the first run for the Solar 195 tool. The run started 01-Aug. at 16719' MD. MWD quit pulsing after 55 circulating hours. Drilled ahead 19 hours without real-time MWD. Tool logged 2 hours after failure before short in end plug turned the subbus off. Maximum temperature prior to failure was $360^{\circ} \mathrm{F}$. and maximum temperature recorded in tool was 367 deg. F. Pulser failed post-run retraction test. Run 600 with Solar 195 tool began 06-Aug 17173' MD. Logged 130' of data lost on prior run and started drilling at 2200 06-Aug. MWD quit pulsing at 05:30 07-Aug. Drilled ahead to TD without MWD. ${ }^{-} \lll$ 


\section{Summary of MWD runs}

\begin{tabular}{|c|c|c|c|c|c|c|c|c|c|c|c|c|c|c|c|}
\hline $\begin{array}{l}\text { Run } \\
\text { No. }\end{array}$ & $\begin{array}{l}\text { Bit } \\
\text { No. }\end{array}$ & $\begin{array}{l}\text { Hole } \\
\text { Size } \\
\text { (in) }\end{array}$ & $\begin{array}{l}\text { MWD } \\
\text { Sensors }\end{array}$ & $\begin{array}{l}\text { Start } \\
\text { Depth } \\
\text { (ft) }\end{array}$ & $\begin{array}{l}\text { End } \\
\text { Depth } \\
(\mathrm{ft})\end{array}$ & $\begin{array}{c}\text { Drill/Wipe } \\
\text { Distance } \\
(\mathrm{ft})\end{array}$ & $\begin{array}{l}\text { Run Start } \\
\text { Date Time }\end{array}$ & $\begin{array}{l}\text { Run End } \\
\text { Date Time }\end{array}$ & $\begin{array}{l}\text { BRT } \\
\text { Hrs. }\end{array}$ & $\begin{array}{l}\text { Oper. } \\
\text { Hrs. }\end{array}$ & $\begin{array}{l}\text { Circ. } \\
\text { Hrs. }\end{array}$ & $\begin{array}{l}\text { Max. } \\
\text { Temp. } \\
\text { (degF) }\end{array}$ & $\begin{array}{l}\text { Serv } \\
\text { Int. }\end{array}$ & $\begin{array}{l}\text { Trip for } \\
\text { MWD }\end{array}$ & $\begin{array}{l}\text { Failure } \\
\text { Type }\end{array}$ \\
\hline 0100 & 0100 & 6.75 & DIR & 14153.00 & 14212.00 & 59.00 & 09-Jul-01 20:00 & 12-Jul-01 14:00 & 66.00 & 66.00 & 50.00 & 302.00 & No & No & \\
\hline 0200 & 0200 & 6.75 & DIR-GR & 14212.00 & 15094.00 & 882.00 & 12-Jul-01 14:00 & 19-Jul-01 11:00 & 165.00 & 165.00 & 136.00 & 289.00 & Yes & Yes & Pulser \\
\hline 0300 & 0300 & 6.75 & DIR-GR & 15094.00 & 15195.00 & 101.00 & 19-Jul-01 12:00 & 20-Jul-01 23:00 & 35.00 & 35.00 & 18.00 & 304.00 & Yes & Yes & Pulser \\
\hline 0400 & 0400 & 6.75 & DIR-GR & 15195.00 & 16719.00 & 1524.00 & 21-Jul-01 01:00 & 31-Jul-01 13:30 & 252.50 & 252.50 & 213.00 & 318.00 & No & No & \\
\hline 0500 & 0500 & 6.75 & DIR-GR & 16719.00 & 17173.00 & 454.00 & 01-Aug-01 17:30 & 06-Aug-01 02:30 & 105.00 & 105.00 & 74.00 & 353.00 & Yes & Yes & Pulser \\
\hline 0600 & 0600 & 6.75 & DIR-GR & 17173.00 & 17777.00 & 604.00 & 06-Aug-01 03:30 & 13-Aug-01 22:00 & 186.50 & 186.50 & 106.00 & 360.00 & Yes & No & Pulser \\
\hline 0601 & 0600 & 0.00 & & 17173.00 & 17777.00 & 604.00 & 06-Aug-01 03:30 & 13-Aug-01 22:00 & 186.50 & 186.50 & 106.00 & 360.00 & Yes & No & \\
\hline 4000 & 0 & 0.00 & & 0.00 & 0.00 & 0.00 & 09-Aug-01 16:17 & 09-Aug-01 16:17 & 0.00 & 0.00 & 0.00 & 0.00 & No & No & \\
\hline
\end{tabular}

TOTALS $====>\quad 4228.00$

$996.50 \quad 996.50 \quad 703.00$

53 
Bitrun Summary

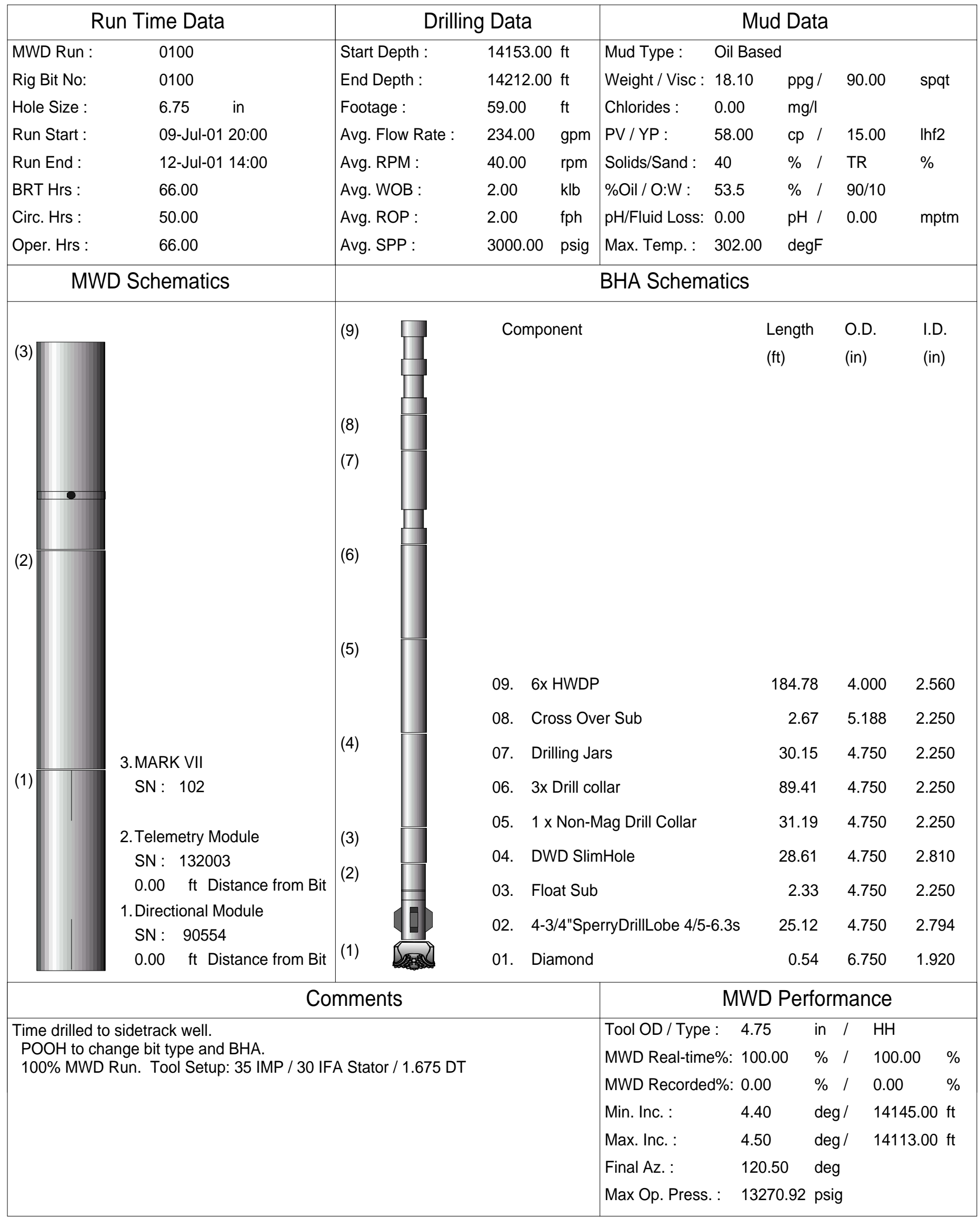


Bitrun Summary

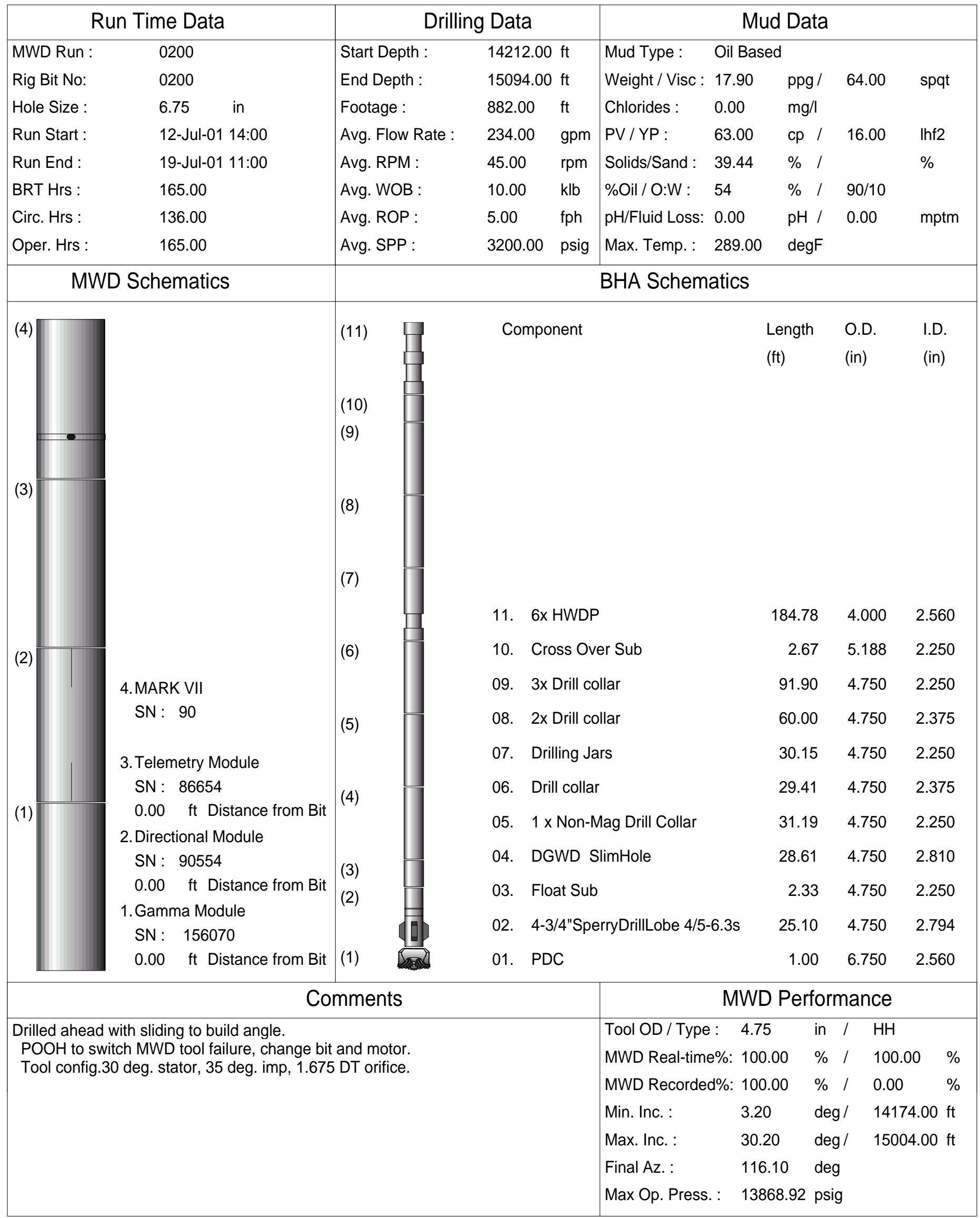


Bitrun Summary

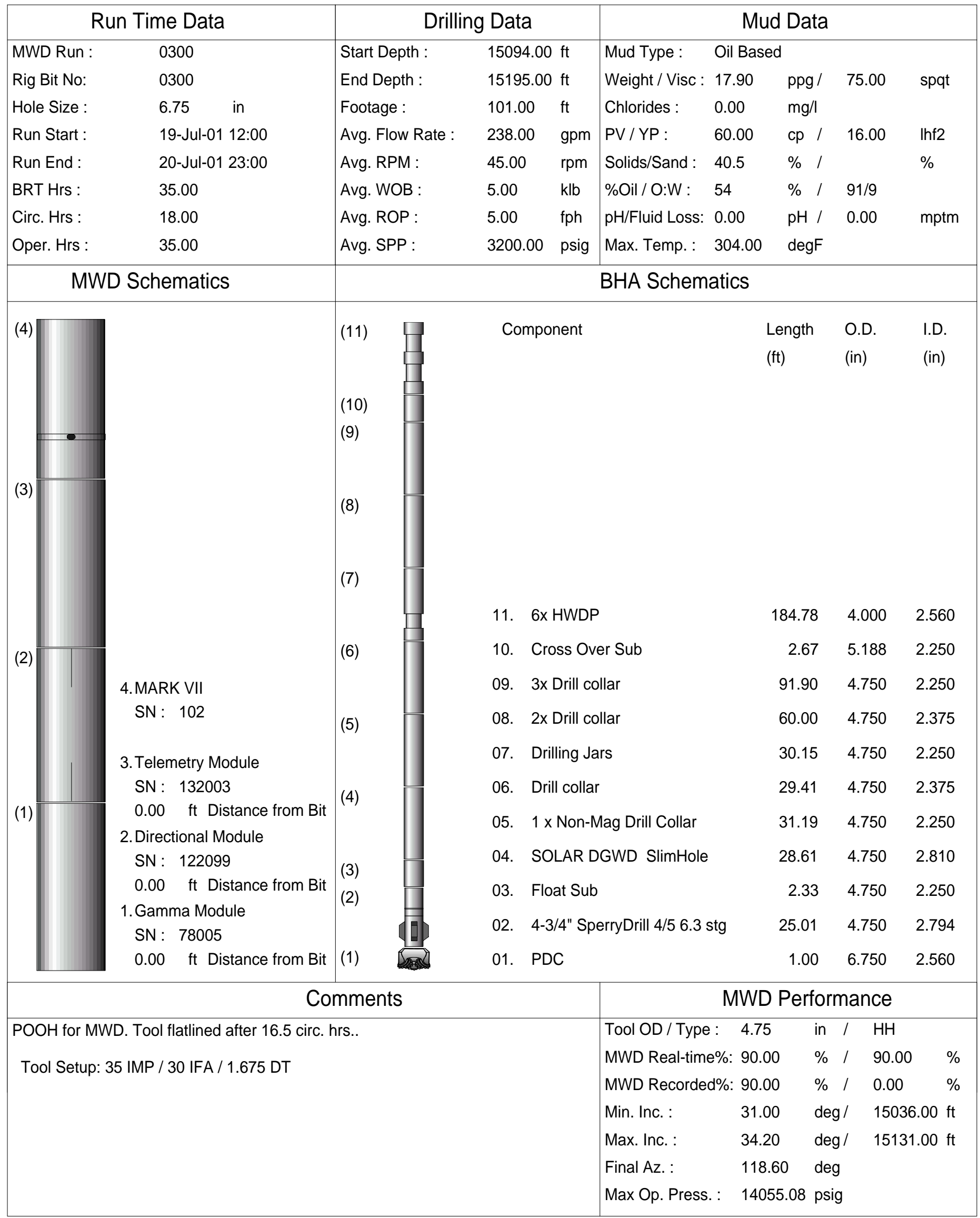


Bitrun Summary

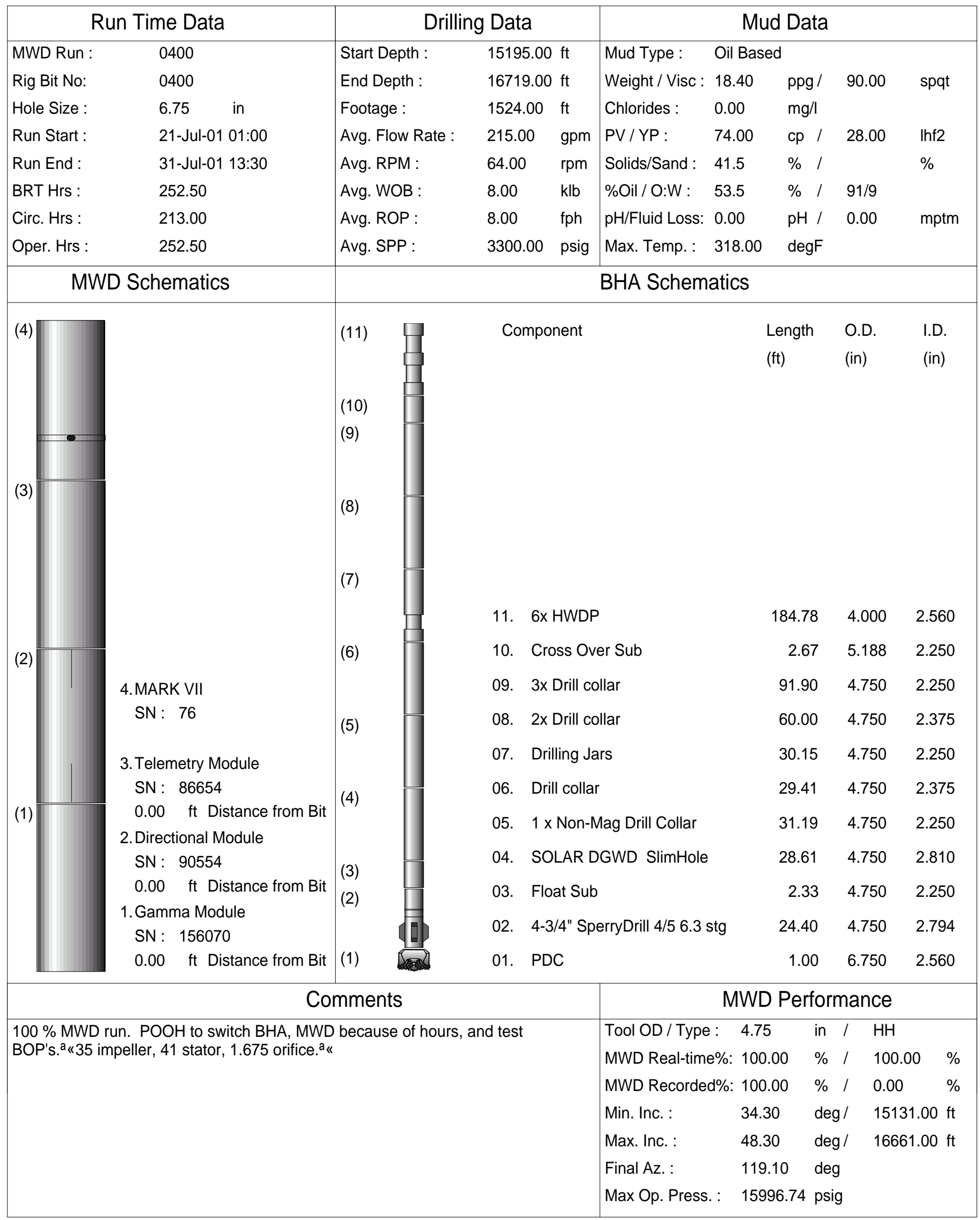


Bitrun Summary

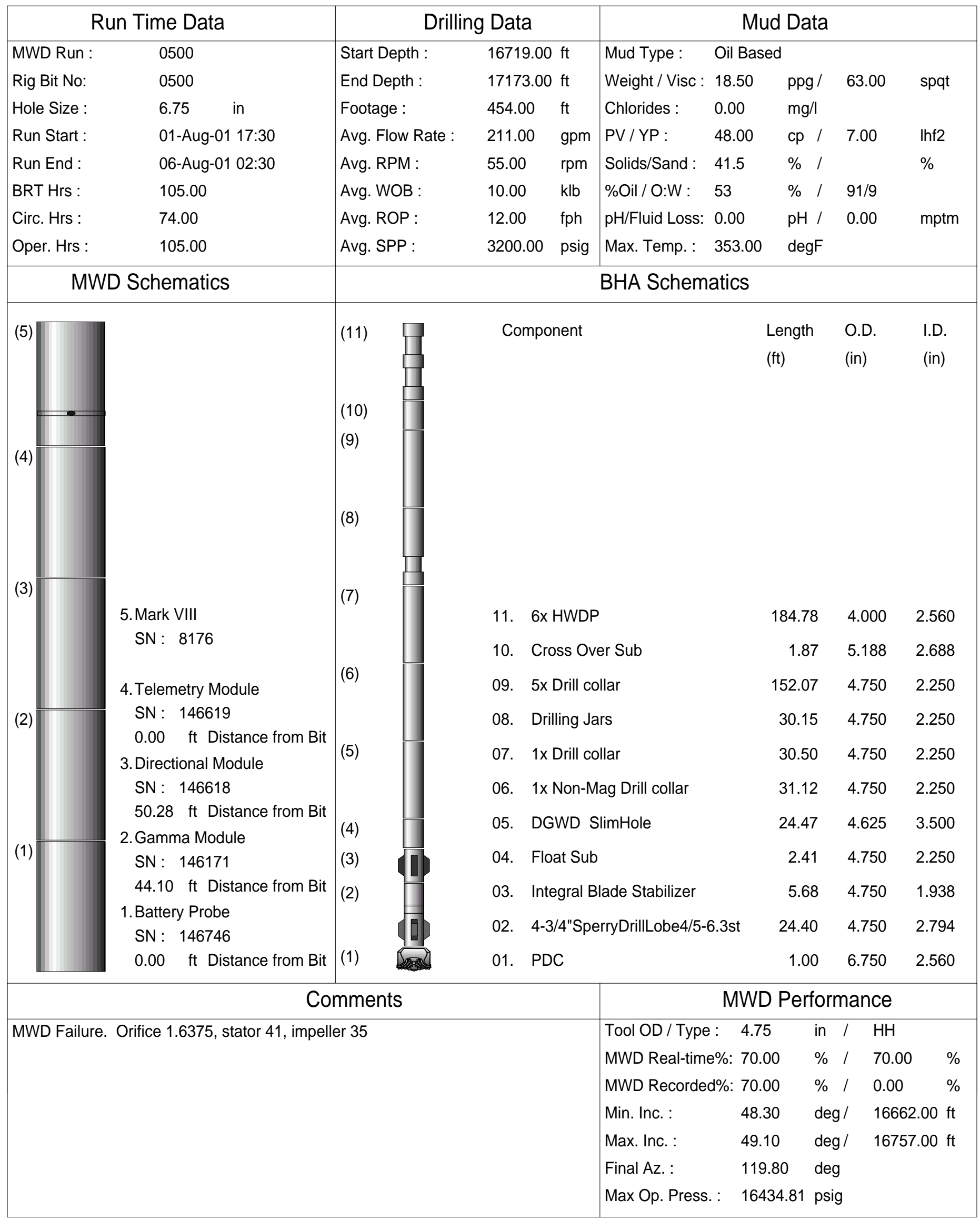


Bitrun Summary

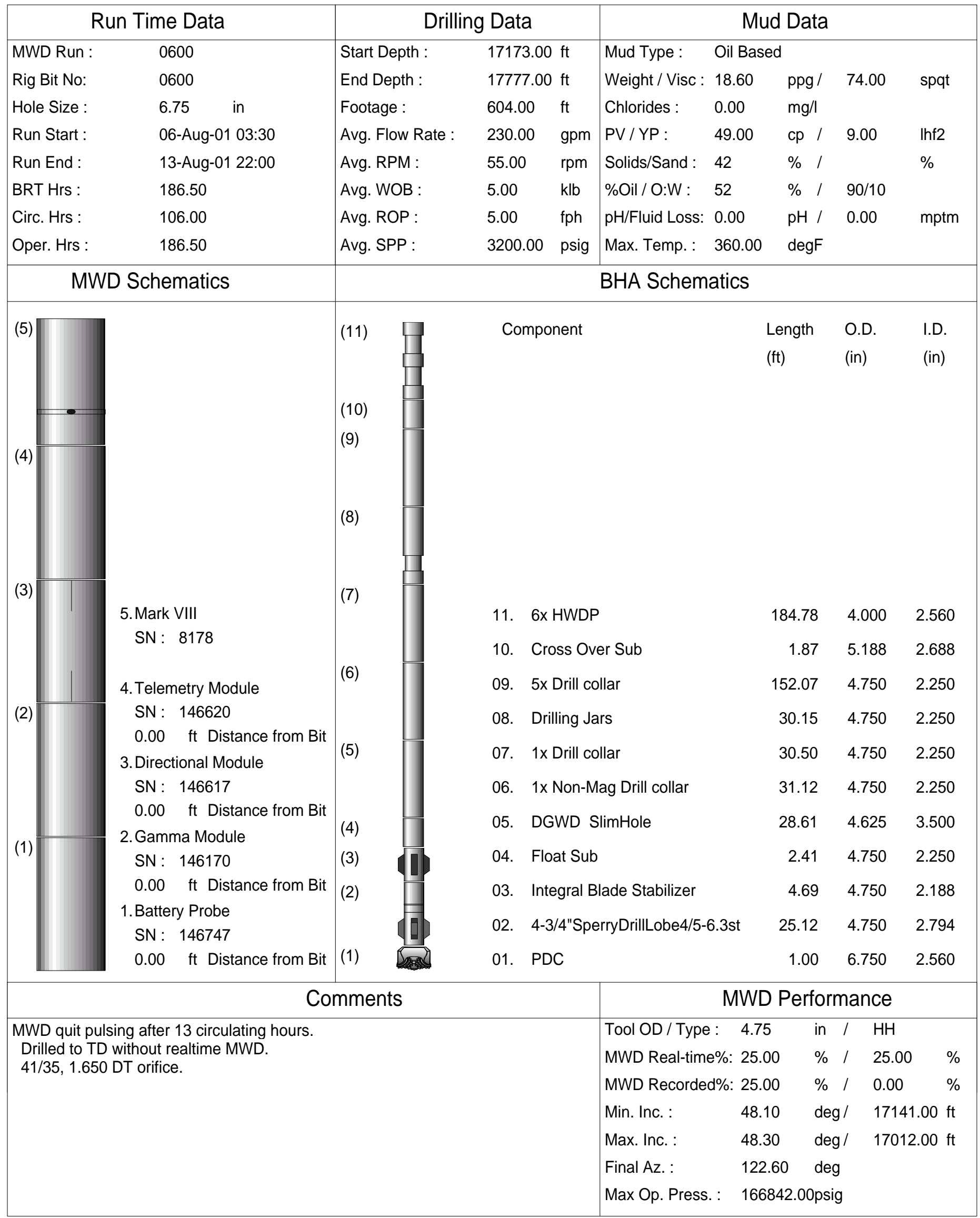




\section{Directional Survey Data}

\begin{tabular}{|c|c|c|c|c|c|c|c|}
\hline $\begin{array}{l}\text { Measured } \\
\text { Depth } \\
\text { (feet) }\end{array}$ & $\begin{array}{l}\text { Inclination } \\
\text { (degrees) }\end{array}$ & $\begin{array}{l}\text { Direction } \\
\text { (degrees) }\end{array}$ & $\begin{array}{c}\text { Vertical } \\
\text { Depth } \\
\text { (feet) }\end{array}$ & $\begin{array}{l}\text { Latitude } \\
\text { (feet) }\end{array}$ & $\begin{array}{c}\text { Departure } \\
\text { (feet) }\end{array}$ & $\begin{array}{c}\text { Vertical } \\
\text { Section } \\
\text { (feet) }\end{array}$ & $\begin{array}{l}\text { Dogleg } \\
\text { (deg/100f) }\end{array}$ \\
\hline 14072.00 & 3.68 & 105.75 & 14067.00 & $109.35 \mathrm{~N}$ & $23.75 \mathrm{~W}$ & -78.82 & TIE-IN \\
\hline 14113.00 & 4.50 & 115.00 & 14107.90 & $108.31 \mathrm{~N}$ & $21.03 \mathrm{~W}$ & -75.97 & 2.56 \\
\hline 14145.00 & 4.40 & 120.50 & 14139.80 & $107.16 \mathrm{~N}$ & $18.83 \mathrm{~W}$ & -73.49 & 1.37 \\
\hline 14174.00 & 3.20 & 154.50 & 14168.74 & $105.86 \mathrm{~N}$ & $17.52 \mathrm{~W}$ & -71.70 & 8.62 \\
\hline 14206.00 & 5.90 & 195.90 & 14200.64 & $103.48 \mathrm{~N}$ & $17.59 \mathrm{~W}$ & -70.47 & 12.77 \\
\hline 14238.00 & 7.80 & 186.90 & 14232.41 & $99.74 \mathrm{~N}$ & $18.30 \mathrm{~W}$ & -69.06 & 6.80 \\
\hline 14269.00 & 8.50 & 177.00 & 14263.10 & $95.36 \mathrm{~N}$ & $18.43 \mathrm{~W}$ & -66.82 & 5.05 \\
\hline 14301.00 & 9.40 & 169.30 & 14294.71 & $90.43 \mathrm{~N}$ & $17.82 \mathrm{~W}$ & -63.65 & 4.68 \\
\hline 14333.00 & 9.80 & 159.70 & 14326.27 & $85.31 \mathrm{~N}$ & $16.39 \mathrm{~W}$ & -59.69 & 5.15 \\
\hline 14365.00 & 10.60 & 147.10 & 14357.76 & $80.28 \mathrm{~N}$ & $13.85 \mathrm{~W}$ & -54.84 & 7.39 \\
\hline 14397.00 & 11.20 & 143.70 & 14389.19 & $75.31 \mathrm{~N}$ & $10.41 \mathrm{~W}$ & -49.27 & 2.75 \\
\hline 14429.00 & 11.60 & 142.80 & 14420.56 & $70.24 \mathrm{~N}$ & $6.63 \mathrm{~W}$ & -43.35 & 1.37 \\
\hline 14461.00 & 12.30 & 137.20 & 14451.86 & $65.18 \mathrm{~N}$ & $2.37 \mathrm{~W}$ & -37.04 & 4.23 \\
\hline 14493.00 & 12.70 & 131.30 & 14483.11 & $60.35 \mathrm{~N}$ & $2.59 \mathrm{E}$ & -30.26 & 4.18 \\
\hline 14525.00 & 13.40 & 124.40 & 14514.28 & $55.94 \mathrm{~N}$ & $8.30 \mathrm{E}$ & -23.08 & 5.33 \\
\hline 14557.00 & 14.20 & 121.00 & 14545.36 & $51.82 \mathrm{~N}$ & $14.72 \mathrm{E}$ & -15.45 & 3.56 \\
\hline 14588.00 & 15.70 & 117.10 & 14575.31 & $47.95 \mathrm{~N}$ & $21.71 \mathrm{E}$ & -7.47 & 5.82 \\
\hline 14620.00 & 16.80 & 117.80 & 14606.03 & $43.82 \mathrm{~N}$ & $29.66 \mathrm{E}$ & 1.44 & 3.49 \\
\hline 14652.00 & 17.50 & 116.90 & 14636.61 & $39.49 \mathrm{~N}$ & $38.04 \mathrm{E}$ & 10.84 & 2.34 \\
\hline 14684.00 & 18.50 & 115.60 & 14667.04 & $35.12 \mathrm{~N}$ & $46.91 \mathrm{E}$ & 20.67 & 3.37 \\
\hline 14716.00 & 19.30 & 115.60 & 14697.32 & $30.64 \mathrm{~N}$ & $56.26 \mathrm{E}$ & 30.96 & 2.50 \\
\hline 14749.00 & 20.20 & 115.40 & 14728.37 & $25.84 \mathrm{~N}$ & $66.32 \mathrm{E}$ & 42.03 & 2.73 \\
\hline 14781.00 & 21.50 & 116.00 & 14758.28 & $20.90 \mathrm{~N}$ & $76.58 \mathrm{E}$ & 53.34 & 4.12 \\
\hline 14813.00 & 23.00 & 116.70 & 14787.89 & $15.52 \mathrm{~N}$ & $87.44 \mathrm{E}$ & 65.38 & 4.76 \\
\hline 14845.00 & 23.80 & 116.70 & 14817.26 & $9.81 \mathrm{~N}$ & $98.79 \mathrm{E}$ & 78.02 & 2.50 \\
\hline 14877.00 & 24.70 & 117.30 & 14846.44 & $3.84 \mathrm{~N}$ & $110.50 \mathrm{E}$ & 91.11 & 2.92 \\
\hline 14909.00 & 25.70 & 117.30 & 14875.39 & $2.41 \mathrm{~S}$ & $122.61 \mathrm{E}$ & 104.67 & 3.13 \\
\hline 14941.00 & 27.20 & 116.50 & 14904.04 & $8.86 \mathrm{~S}$ & $135.32 \mathrm{E}$ & 118.86 & 4.82 \\
\hline 14973.00 & 28.70 & 115.90 & 14932.31 & $15.48 \mathrm{~S}$ & $148.78 \mathrm{E}$ & 133.76 & 4.77 \\
\hline 15004.00 & 30.20 & 116.10 & 14959.30 & $22.16 \mathrm{~S}$ & $162.48 \mathrm{E}$ & 148.91 & 4.85 \\
\hline 15036.00 & 31.00 & 115.00 & 14986.85 & $29.18 \mathrm{~S}$ & $177.17 \mathrm{E}$ & 165.07 & 3.05 \\
\hline 15068.00 & 31.60 & 113.90 & 15014.19 & $36.06 \mathrm{~S}$ & $192.31 \mathrm{E}$ & 181.53 & 2.59 \\
\hline 15099.00 & 33.00 & 115.00 & 15040.39 & $42.92 \mathrm{~S}$ & $207.39 \mathrm{E}$ & 197.93 & 4.90 \\
\hline 15131.00 & 34.30 & 117.30 & 15067.03 & $50.74 \mathrm{~S}$ & $223.30 \mathrm{E}$ & 215.55 & 5.69 \\
\hline 15162.00 & 35.80 & 118.00 & 15092.41 & $59.00 \mathrm{~S}$ & $239.06 \mathrm{E}$ & 233.29 & 5.01 \\
\hline 15194.00 & 37.00 & 118.70 & 15118.16 & $68.02 \mathrm{~S}$ & $255.78 \mathrm{E}$ & 252.23 & 3.97 \\
\hline 15226.00 & 38.10 & 118.70 & 15143.53 & $77.39 \mathrm{~S}$ & $272.88 \mathrm{E}$ & 271.69 & 3.44 \\
\hline 15258.00 & 38.80 & 119.30 & 15168.59 & $87.03 \mathrm{~S}$ & $290.28 \mathrm{E}$ & 291.55 & 2.48 \\
\hline 15290.00 & 39.50 & 120.10 & 15193.41 & $97.04 \mathrm{~S}$ & $307.83 \mathrm{E}$ & 311.73 & 2.70 \\
\hline 15321.00 & 39.60 & 120.40 & 15217.31 & $106.99 \mathrm{~S}$ & $324.88 \mathrm{E}$ & 331.45 & 0.70 \\
\hline
\end{tabular}




\section{Directional Survey Data}

\begin{tabular}{|c|c|c|c|c|c|c|c|}
\hline $\begin{array}{l}\text { Measured } \\
\text { Depth } \\
\text { (feet) }\end{array}$ & $\begin{array}{l}\text { Inclination } \\
\text { (degrees) }\end{array}$ & $\begin{array}{l}\text { Direction } \\
\text { (degrees) }\end{array}$ & $\begin{array}{c}\text { Vertical } \\
\text { Depth } \\
\text { (feet) }\end{array}$ & $\begin{array}{l}\text { Latitude } \\
\text { (feet) }\end{array}$ & $\begin{array}{c}\text { Departure } \\
\text { (feet) }\end{array}$ & $\begin{array}{c}\text { Vertical } \\
\text { Section } \\
\text { (feet) }\end{array}$ & $\begin{array}{l}\text { Dogleg } \\
\text { (deg/100f) }\end{array}$ \\
\hline 15352.00 & 39.80 & 119.80 & 15241.16 & $116.92 \mathrm{~S}$ & $342.02 \mathrm{E}$ & 351.23 & 1.39 \\
\hline 15384.00 & 40.70 & 118.20 & 15265.59 & $126.94 \mathrm{~S}$ & $360.10 \mathrm{E}$ & 371.87 & 4.28 \\
\hline 15416.00 & 41.70 & 117.60 & 15289.67 & $136.80 \mathrm{~S}$ & $378.73 \mathrm{E}$ & 392.88 & 3.36 \\
\hline 15448.00 & 42.30 & 117.00 & 15313.45 & $146.62 \mathrm{~S}$ & $397.75 \mathrm{E}$ & 414.20 & 2.26 \\
\hline 15479.00 & 42.70 & 117.20 & 15336.30 & $156.16 \mathrm{~S}$ & $416.40 \mathrm{E}$ & 435.05 & 1.36 \\
\hline 15511.00 & 43.00 & 117.10 & 15359.76 & $166.09 \mathrm{~S}$ & $435.76 \mathrm{E}$ & 456.72 & 0.96 \\
\hline 15543.00 & 43.10 & 117.20 & 15383.15 & $176.06 \mathrm{~S}$ & $455.20 \mathrm{E}$ & 478.47 & 0.38 \\
\hline 15575.00 & 43.70 & 116.90 & 15406.40 & $186.06 \mathrm{~S}$ & $474.78 \mathrm{E}$ & 500.35 & 1.98 \\
\hline 15607.00 & 43.80 & 117.10 & 15429.51 & $196.10 \mathrm{~S}$ & $494.50 \mathrm{E}$ & 522.38 & 0.53 \\
\hline 15639.00 & 44.00 & 117.00 & 15452.57 & $206.20 \mathrm{~S}$ & $514.26 \mathrm{E}$ & 544.47 & 0.66 \\
\hline 15671.00 & 44.20 & 117.10 & 15475.55 & $216.32 \mathrm{~S}$ & $534.09 \mathrm{E}$ & 566.63 & 0.66 \\
\hline 15703.00 & 44.30 & 116.90 & 15498.47 & $226.46 \mathrm{~S}$ & $553.99 \mathrm{E}$ & 588.86 & 0.54 \\
\hline 15735.00 & 44.40 & 117.50 & 15521.35 & $236.69 \mathrm{~S}$ & $573.88 \mathrm{E}$ & 611.13 & 1.35 \\
\hline 15766.00 & 44.70 & 117.10 & 15543.45 & $246.66 \mathrm{~S}$ & $593.21 \mathrm{E}$ & 632.79 & 1.33 \\
\hline 15799.00 & 44.90 & 116.80 & 15566.86 & $257.20 \mathrm{~S}$ & $613.94 \mathrm{E}$ & 655.93 & 0.88 \\
\hline 15831.00 & 45.30 & 116.70 & 15589.45 & $267.40 \mathrm{~S}$ & $634.18 \mathrm{E}$ & 678.48 & 1.27 \\
\hline 15863.00 & 45.40 & 116.10 & 15611.94 & 277.52 S & $654.57 \mathrm{E}$ & 701.12 & 1.37 \\
\hline 15895.00 & 45.60 & 116.30 & 15634.37 & $287.60 \mathrm{~S}$ & $675.05 \mathrm{E}$ & 723.80 & 0.77 \\
\hline 15927.00 & 45.60 & 115.60 & 15656.76 & $297.60 \mathrm{~S}$ & $695.61 \mathrm{E}$ & 746.51 & 1.56 \\
\hline 15959.00 & 45.90 & 115.90 & 15679.09 & $307.56 \mathrm{~S}$ & $716.25 \mathrm{E}$ & 769.28 & 1.15 \\
\hline 15991.00 & 46.00 & 115.70 & 15701.33 & $317.57 \mathrm{~S}$ & $736.96 \mathrm{E}$ & 792.12 & 0.55 \\
\hline 16023.00 & 46.10 & 115.20 & 15723.54 & $327.47 \mathrm{~S}$ & $757.76 \mathrm{E}$ & 814.98 & 1.17 \\
\hline 16054.00 & 46.50 & 114.90 & 15744.96 & $336.96 \mathrm{~S}$ & $778.06 \mathrm{E}$ & 837.20 & 1.47 \\
\hline 16086.00 & 46.60 & 115.50 & 15766.97 & $346.85 \mathrm{~S}$ & $799.08 \mathrm{E}$ & 860.24 & 1.40 \\
\hline 16118.00 & 46.90 & 114.60 & 15788.90 & $356.72 \mathrm{~S}$ & $820.20 \mathrm{E}$ & 883.35 & 2.25 \\
\hline 16150.00 & 46.90 & 114.50 & 15810.76 & $366.43 \mathrm{~S}$ & $841.45 \mathrm{E}$ & 906.49 & 0.23 \\
\hline 16182.00 & 47.20 & 114.80 & 15832.56 & $376.20 \mathrm{~S}$ & $862.74 \mathrm{E}$ & 929.69 & 1.16 \\
\hline 16214.00 & 46.70 & 116.20 & 15854.41 & $386.26 \mathrm{~S}$ & $883.85 \mathrm{E}$ & 952.90 & 3.56 \\
\hline 16246.00 & 46.70 & 117.10 & 15876.35 & $396.71 \mathrm{~S}$ & $904.66 \mathrm{E}$ & 976.07 & 2.05 \\
\hline 16278.00 & 46.30 & 118.60 & 15898.38 & $407.55 \mathrm{~S}$ & $925.18 \mathrm{E}$ & 999.20 & 3.62 \\
\hline 16310.00 & 46.50 & 118.80 & 15920.45 & $418.68 \mathrm{~S}$ & $945.51 \mathrm{E}$ & 1022.32 & 0.77 \\
\hline 16342.00 & 46.60 & 119.10 & 15942.46 & $429.92 \mathrm{~S}$ & $965.84 \mathrm{E}$ & 1045.51 & 0.75 \\
\hline 16374.00 & 46.80 & 118.40 & 15964.40 & $441.13 \mathrm{~S}$ & $986.26 \mathrm{E}$ & 1068.74 & 1.71 \\
\hline 16437.00 & 46.00 & 119.10 & 16007.85 & $463.07 \mathrm{~S}$ & 1026.25 E & 1114.27 & 1.50 \\
\hline 16501.00 & 46.40 & 118.70 & 16052.15 & $485.39 \mathrm{~S}$ & $1066.69 \mathrm{E}$ & 1160.37 & 0.77 \\
\hline 16533.00 & 46.60 & 118.70 & 16074.17 & $496.54 \mathrm{~S}$ & 1087.05 E & 1183.53 & 0.62 \\
\hline 16565.00 & 46.80 & 118.60 & 16096.12 & $507.70 \mathrm{~S}$ & $1107.49 \mathrm{E}$ & 1206.76 & 0.67 \\
\hline 16597.00 & 47.20 & 119.20 & 16117.94 & $519.02 \mathrm{~S}$ & $1127.98 \mathrm{E}$ & 1230.12 & 1.86 \\
\hline 16629.00 & 47.70 & 118.90 & 16139.58 & $530.46 \mathrm{~S}$ & $1148.59 \mathrm{E}$ & 1253.65 & 1.71 \\
\hline 16661.00 & 48.30 & 119.10 & 16161.00 & $541.99 \mathrm{~S}$ & $1169.39 \mathrm{E}$ & 1277.39 & 1.93 \\
\hline
\end{tabular}




\section{Directional Survey Data}

\begin{tabular}{|c|c|c|c|c|c|c|c|}
\hline $\begin{array}{c}\text { Measured } \\
\text { Depth } \\
\text { (feet) }\end{array}$ & $\begin{array}{l}\text { Inclination } \\
\text { (degrees) }\end{array}$ & $\begin{array}{l}\text { Direction } \\
\text { (degrees) }\end{array}$ & $\begin{array}{c}\text { Vertical } \\
\text { Depth } \\
\text { (feet) }\end{array}$ & $\begin{array}{l}\text { Latitude } \\
\text { (feet) }\end{array}$ & $\begin{array}{c}\text { Departure } \\
\text { (feet) }\end{array}$ & $\begin{array}{c}\text { Vertical } \\
\text { Section } \\
\text { (feet) }\end{array}$ & $\begin{array}{l}\text { Dogleg } \\
\text { (deg/100f) }\end{array}$ \\
\hline 16693.00 & 49.00 & 118.30 & 16182.14 & $553.53 \mathrm{~S}$ & $1190.46 \mathrm{E}$ & 1301.35 & 2.88 \\
\hline 16757.00 & 49.10 & 118.80 & 16224.08 & $576.63 \mathrm{~S}$ & $1232.92 \mathrm{E}$ & 1349.57 & 0.61 \\
\hline 16821.00 & 48.80 & 119.10 & 16266.11 & $599.99 \mathrm{~S}$ & $1275.15 \mathrm{E}$ & 1397.75 & 0.59 \\
\hline 16885.00 & 48.60 & 119.10 & 16308.35 & $623.37 \mathrm{~S}$ & $1317.16 \mathrm{E}$ & 1445.74 & 0.31 \\
\hline 16949.00 & 48.30 & 119.80 & 16350.80 & $646.92 \mathrm{~S}$ & $1358.87 \mathrm{E}$ & 1493.57 & 0.94 \\
\hline 17012.00 & 48.30 & 121.20 & 16392.71 & $670.79 \mathrm{~S}$ & $1399.40 \mathrm{E}$ & 1540.57 & 1.66 \\
\hline 17077.00 & 48.20 & 121.90 & 16436.00 & $696.17 \mathrm{~S}$ & $1440.72 \mathrm{E}$ & 1589.06 & 0.82 \\
\hline 17141.00 & 48.10 & 122.60 & 16478.70 & $721.61 \mathrm{~S}$ & $1481.04 \mathrm{E}$ & 1636.73 & 0.83 \\
\hline 17777.00 & 48.10 & 122.60 & 16903.44 & $976.65 \mathrm{~S}$ & $1879.84 \mathrm{E}$ & 2110.11 & 0.00 \\
\hline
\end{tabular}




\section{Directional Survey Data}

\section{CALCULATION BASED ON Minimum Curvature METHOD}

SURVEY COORDINATES RELATIVE TO WELL SYSTEM REFERENCE POINT

TVD VALUES GIVEN RELATIVE TO DRILLING MEASUREMENT POINT

VERTICAL SECTION RELATIVE TO WELL HEAD

VERTICAL SECTION IS COMPUTED ALONG A DIRECTION OF 122.53 DEGREES (GRID)

A TOTAL CORRECTION OF 3.98 DEG FROM MAGNETIC NORTH TO GRID NORTH HAS BEEN APPLIED

HORIZONTAL DISPLACEMENT IS RELATIVE TO THE WELL HEAD.

HORIZONTAL DISPLACEMENT(CLOSURE) AT 17777.00 FEET

IS 2118.41 FEET ALONG 117.45 DEGREES (GRID)

TIE-IN SURVEY AT 14072' MD IS PROVIDED BY MULTI-SHOT.

SURVEYS FROM 14113' MD TO 17141' MD IS PROVIDED BY SPERRY-SUN MWD.

SURVEY AT 17141' MD IS PROJECTED TO TD AT 17777' MD.

SPERRY-SUN ENGINEERS, K. MCCOY AND T. BUFFORD. 


\section{Service Interrupt Report}

MWD run number : $\quad 0500$

Rig Bit Number : $\quad 0500$

MWD Run start time/date : 01-Aug-01 17:30

MWD Run end time/date : 06-Aug-01 02:30
Time/Date of Failure : $\quad$ 04-Aug-01 23:00

Depth at time of Failure : $\quad 17015.00 \mathrm{ft}$

Lost Rig Hours :

Rig Activity

Drilling ahead.

Description of Failure

Tool quit pulsing.

\section{Action Taken}

Cycled pumps, changed flow rates, changed pressure tranducer, etc... Drilled ahead 19.5 hrs without MWD.

Operation Impact

POOH for MWD. Lost 130' of data. Delayed data delivery 24 hrs. 20 hrs lost rig time.

\section{Reason for Failure}

Pulser failed poppet retraction test. BM shorted sub bus. 


\section{Service Interrupt Report}

MWD run number : $\quad 0600$

Rig Bit Number : $\quad 0600$

MWD Run start time/date : 06-Aug-01 03:30

MWD Run end time/date : 13-Aug-01 22:00
Time/Date of Failure :

07-Aug-01 05:30

Depth at time of Failure : $\quad 17233.00 \mathrm{ft}$

Lost Rig Hours :

Rig Activity

Drilling ahead.

\section{Description of Failure}

Tool quit pulsing.

\section{Action Taken}

Cycled pumps, changed flow rates, changed pressure tranducer, etc... Drilled ahead to TD without MWD.

Operation Impact

POOH for MWD. Lost 600 ' of data, delayed data delivery 96 hrs.

\section{Reason for Failure}

Found nut on top of poppet. Surface test revealed a broken poppet, and was unable to communicate with TM. Poppet failed poppet retraction test. 


\section{Sperry-Sun, A Halliburton Company}

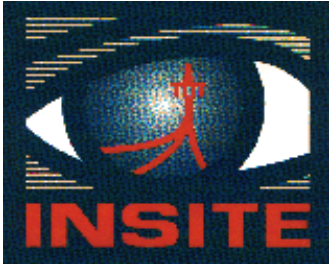




\section{LWD Logs}

- Gamma Ray MD log from 16610 to 16760. Last reading from Solar 175 Gamma at 16681. Depths below this point are from Solar 195 Gamma tool. 
TS01-001-HT195: 〈Solar 195>

01 Aug 2001 - 14 Aug 2001

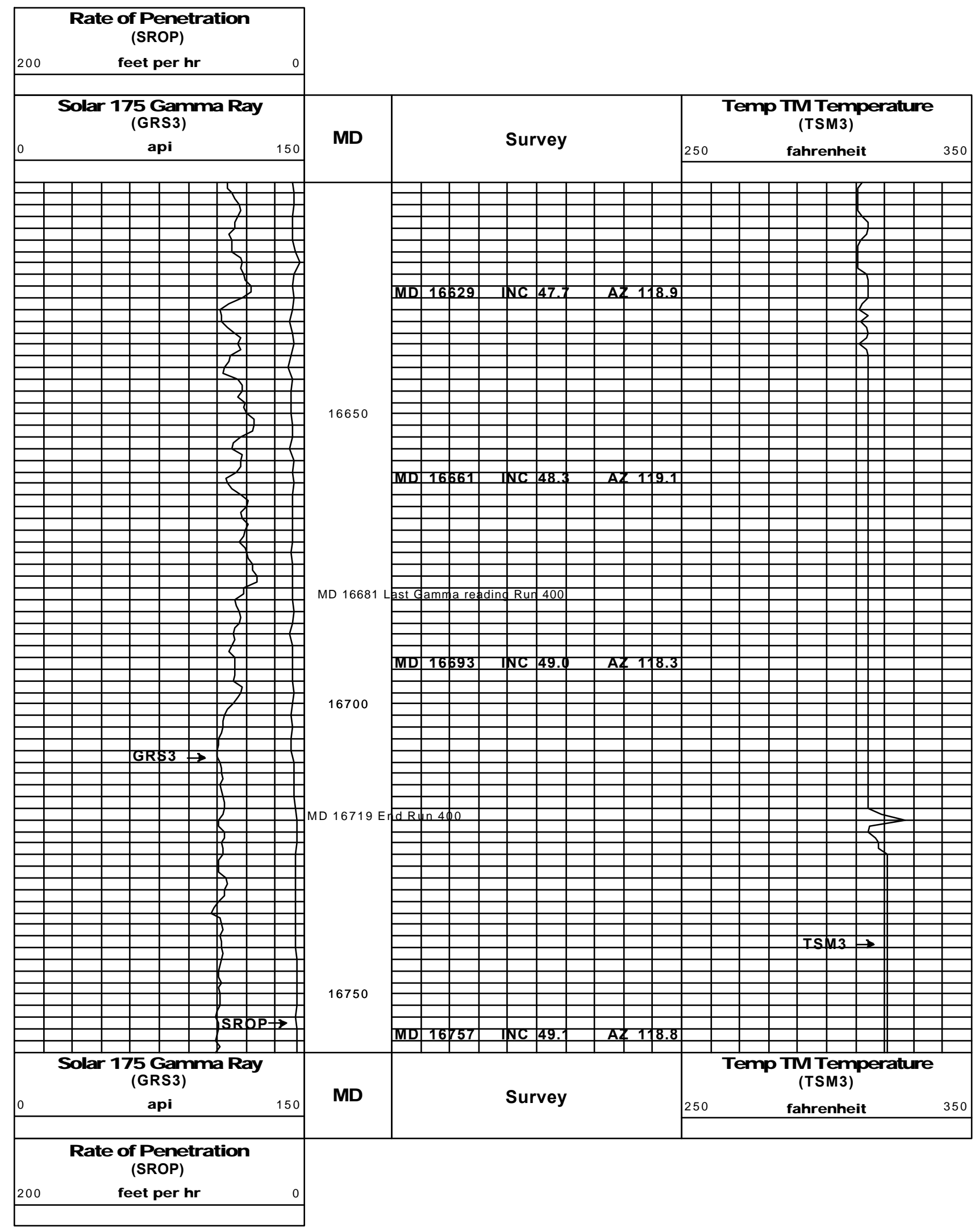




\section{Mud Reports}




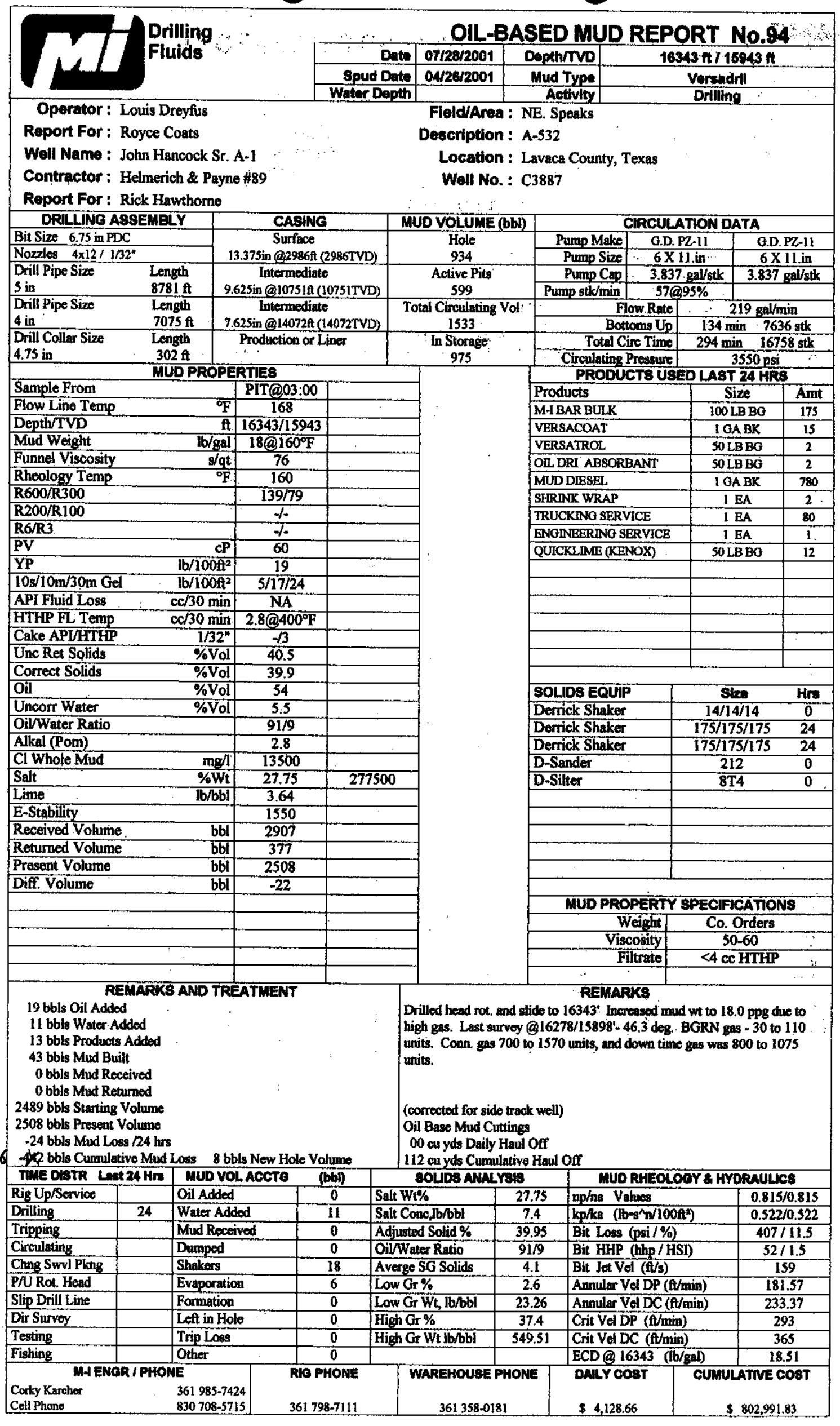




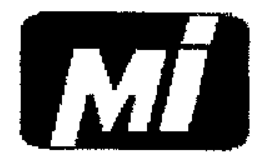

\begin{tabular}{|l|c|c|c|c|c|}
\hline $361-886-3400$ & $\begin{array}{c}\text { WELL } \\
\text { NUMBER }\end{array}$ & $\begin{array}{c}\text { State } \\
\text { TX }\end{array}$ & Colinty & $\begin{array}{c}\text { Well } \\
\text { C3887 }\end{array}$ & S $\pi$ \\
\hline OPERATOR & & & CONTRACT \\
\hline
\end{tabular}

\section{M-I Drih Ig Fluids}

P.O. Box 42842

HOUSTON, TEXAS USA

Louis Dreyfus

OPERATOR REPRESENTATIVE

Royce Coats

\begin{tabular}{|l|l|}
\hline WELL NAME AND NUMBER & FIELD OR BLOC \\
John Hancock Sr. A - 1 & NE Speaks \\
\hline
\end{tabular}

CONTRACTOR

Helmerich \& Payne

CONTRACTOR REPRESENTATIVE

Dale Molar

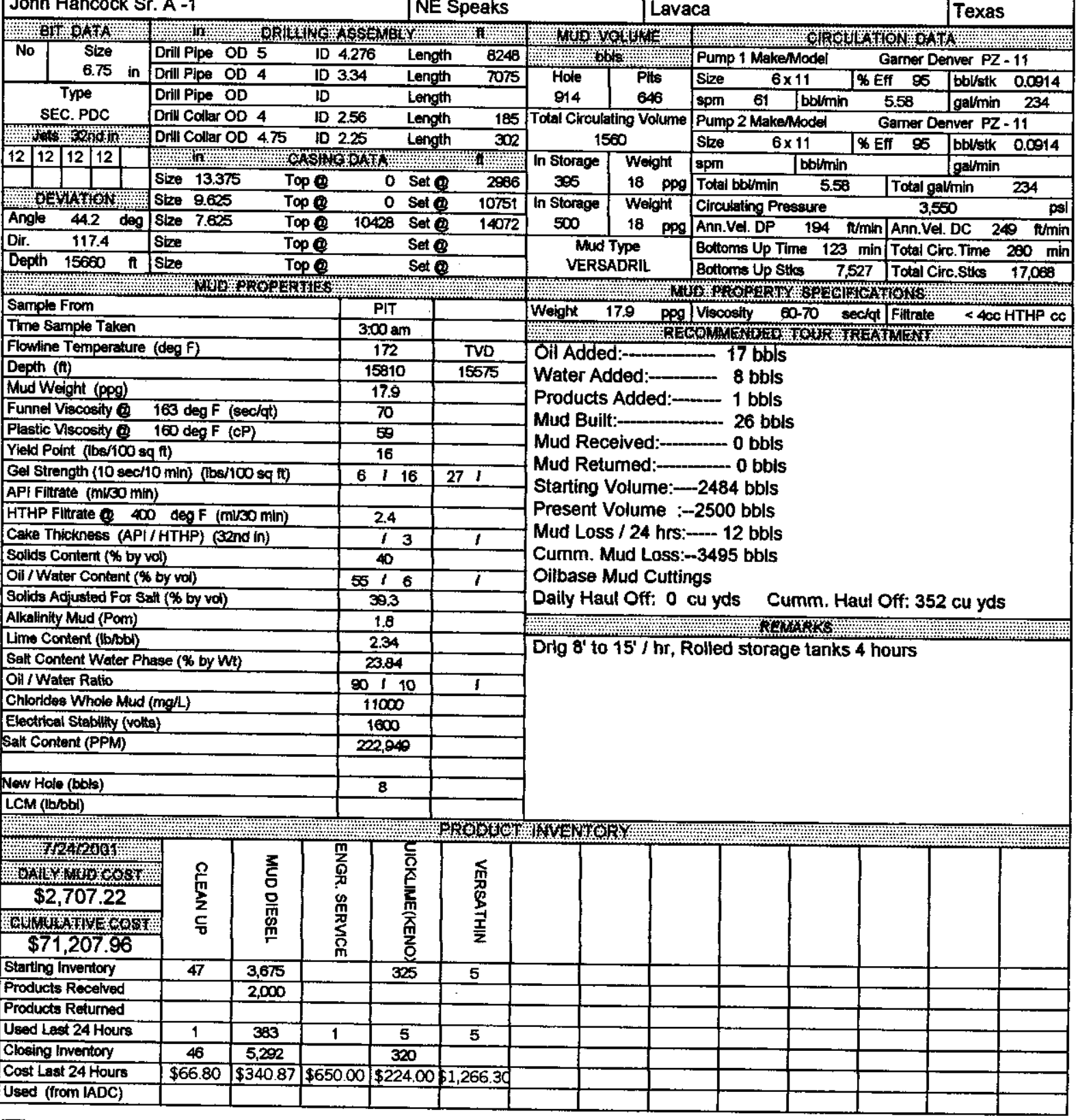

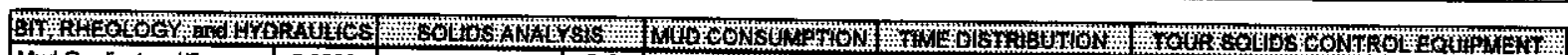

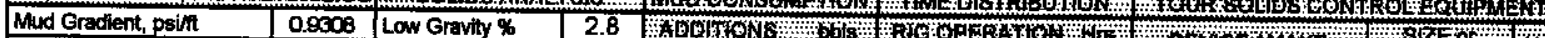

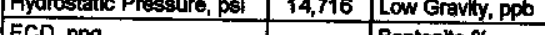
ECD, ppg \begin{tabular}{|l|l|l|l|}
\hline Bit weight (WOB), Ibs & 10 & Bentonite \% \\
\hline
\end{tabular}

\begin{tabular}{|l|c|l|}
\hline Bit RPM, rpm & 70 & Drill Solids $\%$ \\
\hline & & Drill Solids, ppb \\
\hline
\end{tabular}

\begin{tabular}{|l|l|l|}
\hline Back Ground Gas & $50-95$ & Shale CEC, $\mathrm{ppb}$ \\
\hline
\end{tabular}

Connection Gas 300-425 D/B Ratio

\begin{tabular}{|l|c|l}
\hline Gas Cut Mud & 17.7 & High Gravity \% \\
\hline
\end{tabular}

Botom Hole Temp

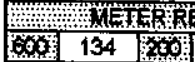

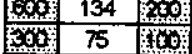
310 High Gravity, ppb

\begin{tabular}{|l|l|}
\hline & \\
\hline & \\
\hline & \\
\hline & \\
\hline & \\
\hline & \\
\hline & \\
\hline
\end{tabular}

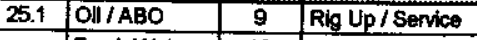

\begin{tabular}{|l|c|l}
\hline Fresh Water & 12 & Drilling \\
\hline
\end{tabular}

Brine Water

Mud Buitt

Mud Transfer

Mud Transfer

\begin{tabular}{|c|l|l|}
\hline & Clrculating \\
\hline 1 & Tripping
\end{tabular}

24.00 Derrick Shaker

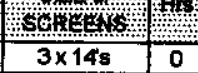

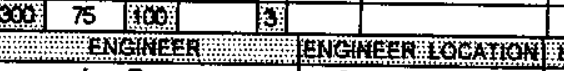
Joe Barnes Corpus Christi

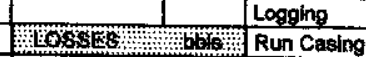

REPORT NUMBER: 9

\begin{tabular}{|l|l|}
\hline Date & $\begin{array}{l}\text { Depth } \\
7 / 24 / 2001\end{array}$ \\
$15810 \mathrm{ft}$. \\
\hline
\end{tabular}

\begin{tabular}{l|l}
\hline Spud Date & Present Activily
\end{tabular}

4/26/2001 TVD-15575 Drlg 8-15'/Hr 89 89 


\section{M-I Drillg Fluids}

P.O. Box 42842

HOUSTON, TEXAS USA

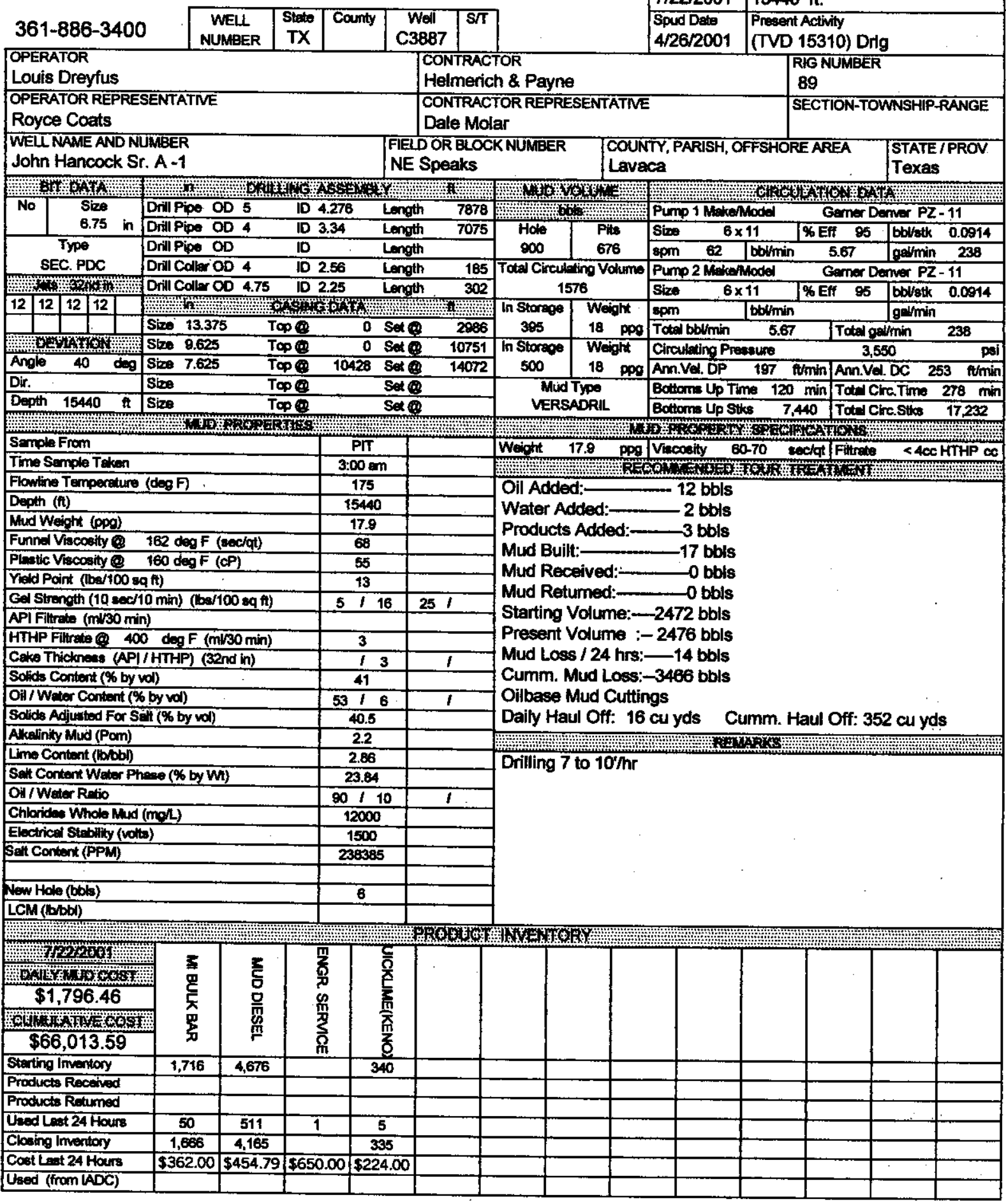

\begin{tabular}{|c|c|c|c|c|c|c|c|c|c|c|}
\hline \multicolumn{2}{|c|}{ EX } & \multicolumn{2}{|c|}{ (6) } & \multicolumn{2}{|c|}{ (2) F } & \multicolumn{2}{|c|}{ Th } & \multicolumn{3}{|c|}{ 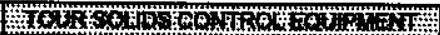 } \\
\hline \multirow{2}{*}{$\begin{array}{l}\text { Mud Gradient, paint } \\
\text { Hydroatatic Preesure, psi }\end{array}$} & 0.9308 & Low Gravty \% & 4.9 & Wo & +6 & F & W & \multirow{2}{*}{ U⿴囗十 } & \multirow{2}{*}{ N } & \multirow{2}{*}{ 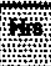 } \\
\hline & 14,372 & Low Gravidy, ppb & 44.2 & OA/ABO & 12 & Rig Up / Senvice & & & & \\
\hline ECD, ppg & 18.37 & Bentonite \% & & Freah Water & 2 & Drilling & 24.00 & Derrick Shaker & $3 \times 14: s$ & 0 \\
\hline Bit woight (WOB), Hos & 7 & Bentonite, ppb & & Brine Woter & & Circuleting & & Derrick Shaker & $3 \times 175$ & 24 \\
\hline \multirow[t]{2}{*}{ Bit RPM, rpm } & 110 & Drill Solids $\%$ & & Mud Buitt & 3 & Tripping & & Derrick Shaker & $3 \times 175$ & 24 \\
\hline & & Drill Solide, ppb & & Mud Transfer & & Suneys & & D-Sender & & 0 \\
\hline Back Ground Gas & 130600 & Shal CEC, ppb & & & & Loging & & D-Sitter & & 0 \\
\hline Connection Gas & $25-55$ & D/B Retio & & 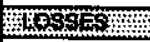 & Pet & Run Casing & & D-Geseer & & 24 \\
\hline Bottom Hole Temp & 300 & High Gravity \% & 35.7 & Mud Lost & 14 & Testing & & & & \\
\hline Water Meter & 42739 & High Grevity, ppo & 524.3 & Mud Durnped & & Cementing & & & & \\
\hline \multicolumn{2}{|c|}{ Pry } & Avg. SG & 4.008 & Mud Transfer & & Coring / Reeming & & & & \\
\hline fors 123 & 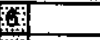 & & & \multicolumn{2}{|c|}{ 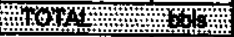 } & & & & & \\
\hline $68 \quad 100$ & in & & & Goin / Loss & 3 & & & & & \\
\hline 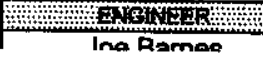 & & 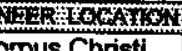 & 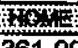 & Atan: & 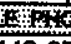 & 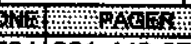 & & REX & Whis & Sthin \\
\hline
\end{tabular}




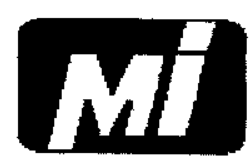

\section{M-I Dril g Fluids}

P.O. Box 42842

HOUSTON, TEXAS USA

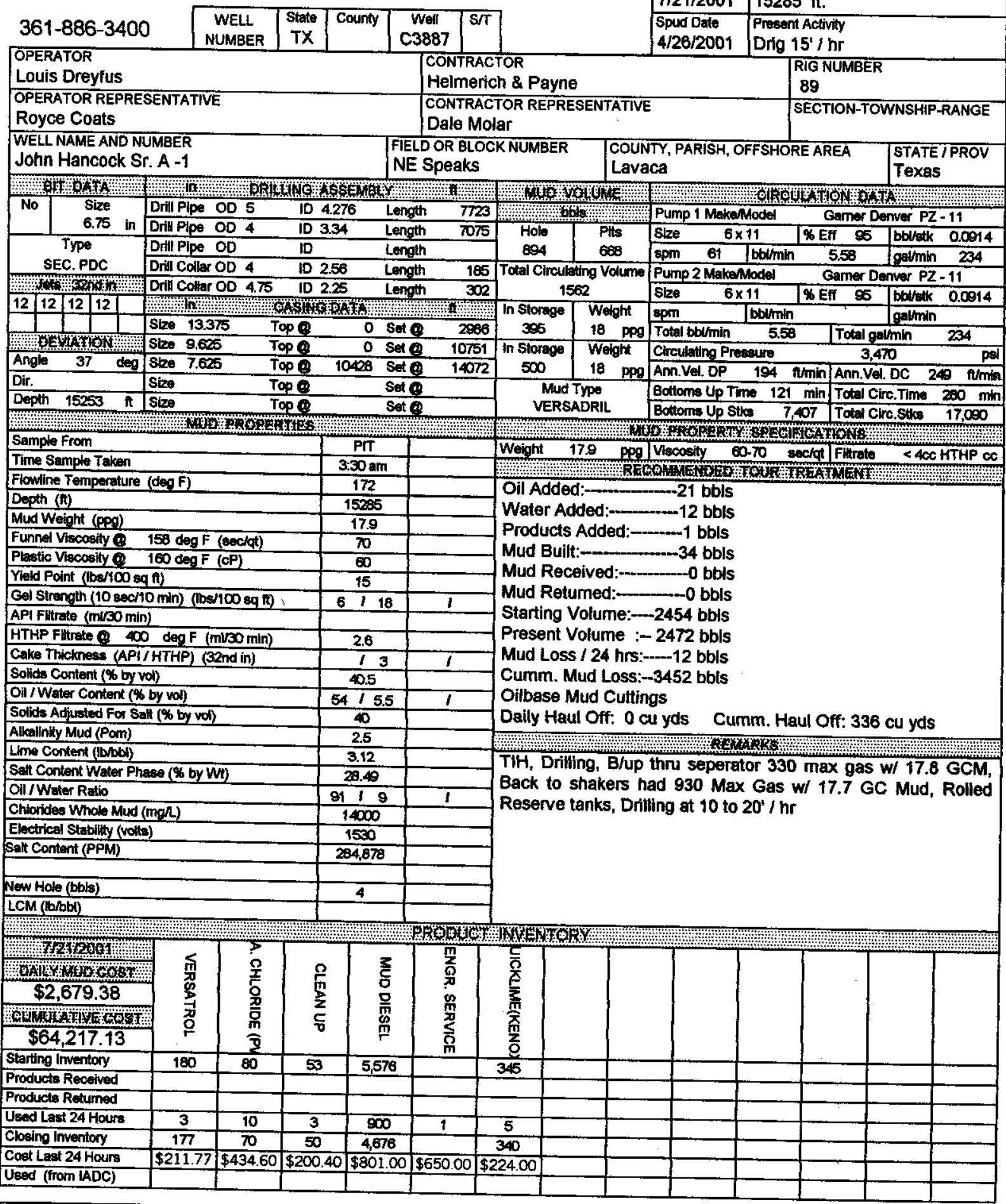

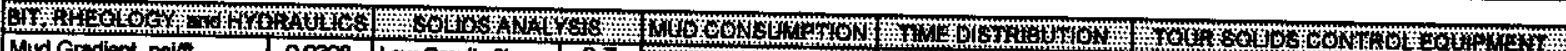

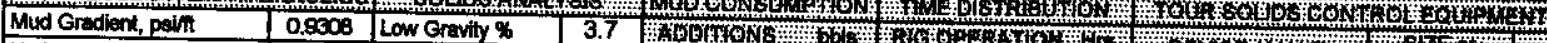

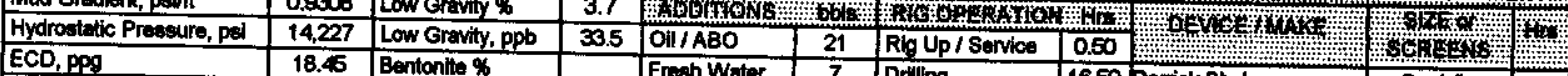

Bit weight $($ WOB $)$, Ibs Bit RPM, rpm

\begin{tabular}{|c|c|c|c|c|c|c|c|c|c|}
\hline Bit weight (wOB), lbs & 7 & Bentonite, ppb & Brine Water & & Circulating & & Derrick Shaker & $3 \times 175$ & 24 \\
\hline Bit RPM, rpm & & Drill Sollds \% & Mud Builk & 1 & Tripping & 5.00 & Derrick Shaker & $3 \times 175$ & 24 \\
\hline & & Drill Solids, ppb & Mud Transfer & & Surveys & & D-Sander & & $\frac{4}{0}$ \\
\hline Back Ground Gas & 45 & Shale CEC, ppb & & & Logging & & D-Silter & & $\frac{1}{0}$ \\
\hline Connection Ges & 160 & D / B Ratio & Fos \&SES & bin: & Run Cosing & & D-Geanar & & \\
\hline
\end{tabular}

Bottom Hole Temp

Water Moter

160 D / B Ratio

\begin{tabular}{c|c}
$295-305$ & High Gravity \% \\
\hline 42470 & High Gravty
\end{tabular}

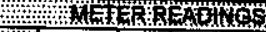

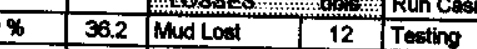

\begin{tabular}{|c|c|c|}
\hline Avg. SG & 5.053 & Mud Transer \\
\hline
\end{tabular}

135 \% 15

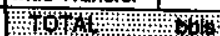

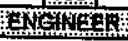
Joe Barnes \begin{tabular}{|c|c|c|c|}
\hline $3:$ & & Gan / Lo8s & 17 \\
\hline
\end{tabular} Cementing Coring / Rearning

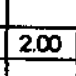

2.00 D-Gaseer |.

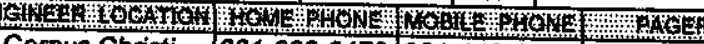
\begin{tabular}{l|l|l|l} 
Corpus Christi & $361-992-6470$ & $361-442-3734$ & $361-442-3734$
\end{tabular}

The recommendations made herein thall not be construed as authorizing the infringement of any valid patent, and are made without arsumption of manufacturer or its author. THE MUD COMPANY or its agents, and are statomente of opinion only. Oral or written etetements ape advieory only and may be rejected by the uner

REPORT NUMBER: 88

Date - Depth

7/21/2001 $15285 \mathrm{ft}$.

pud Date

89

STATE IPROV

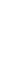

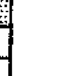




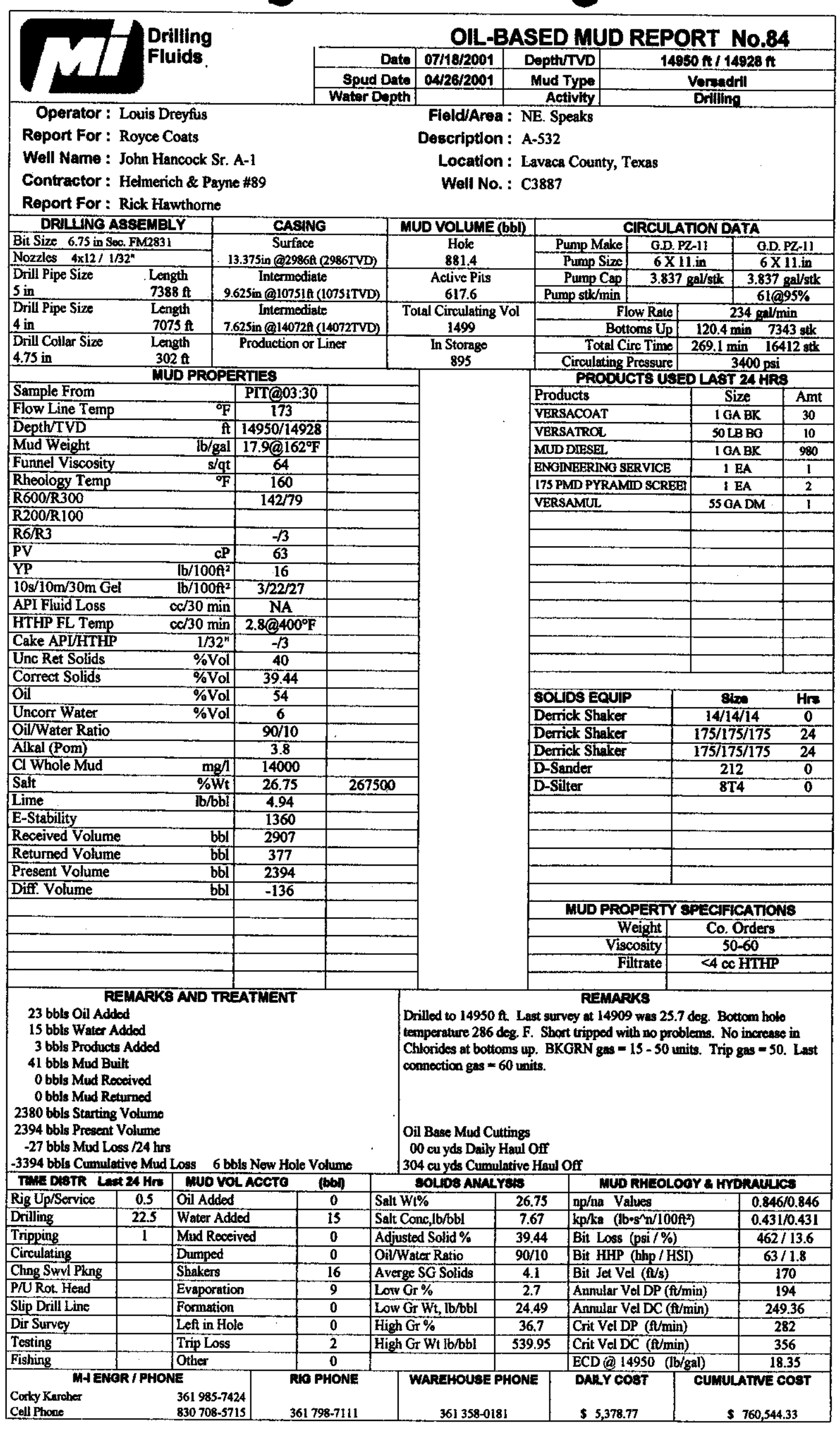




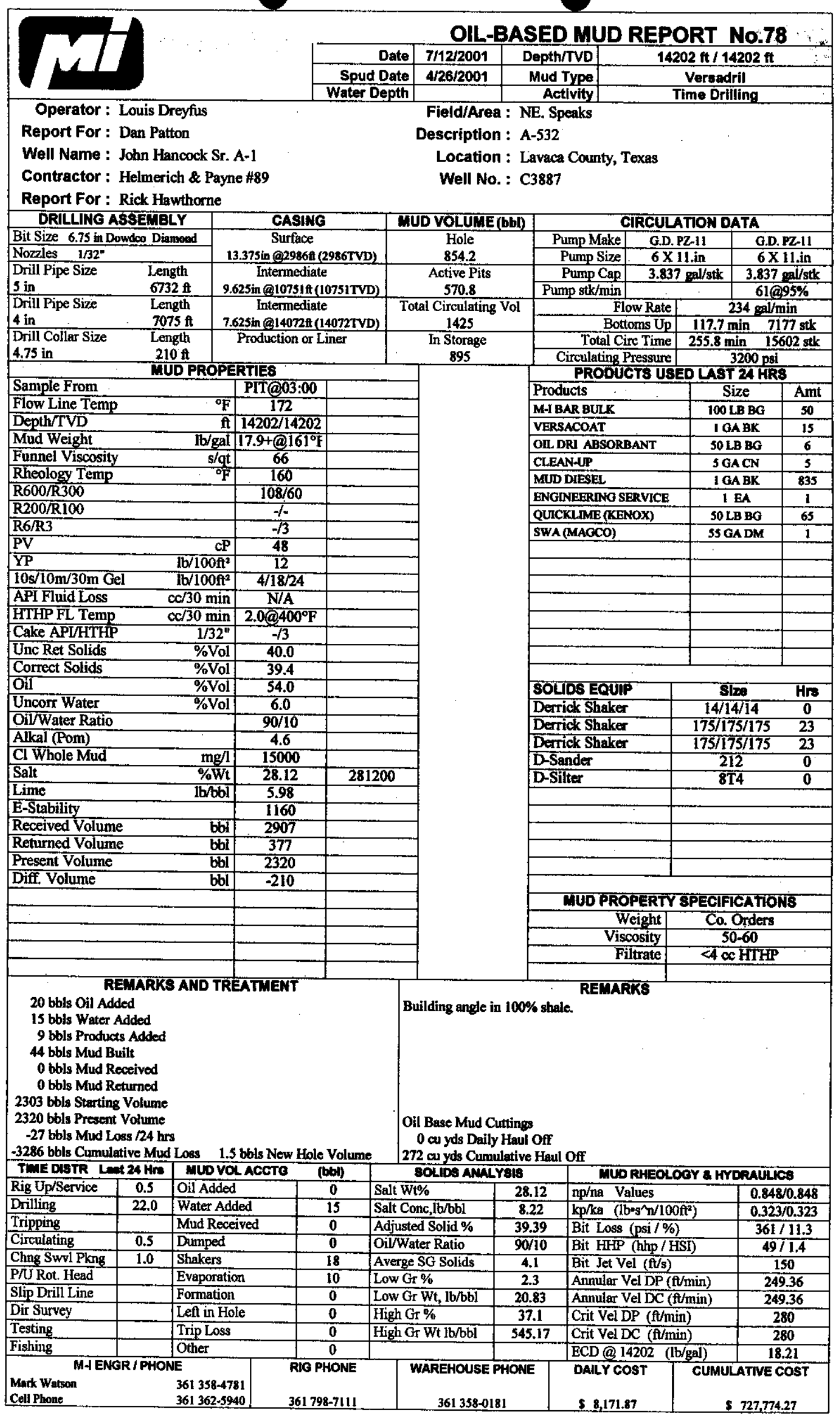




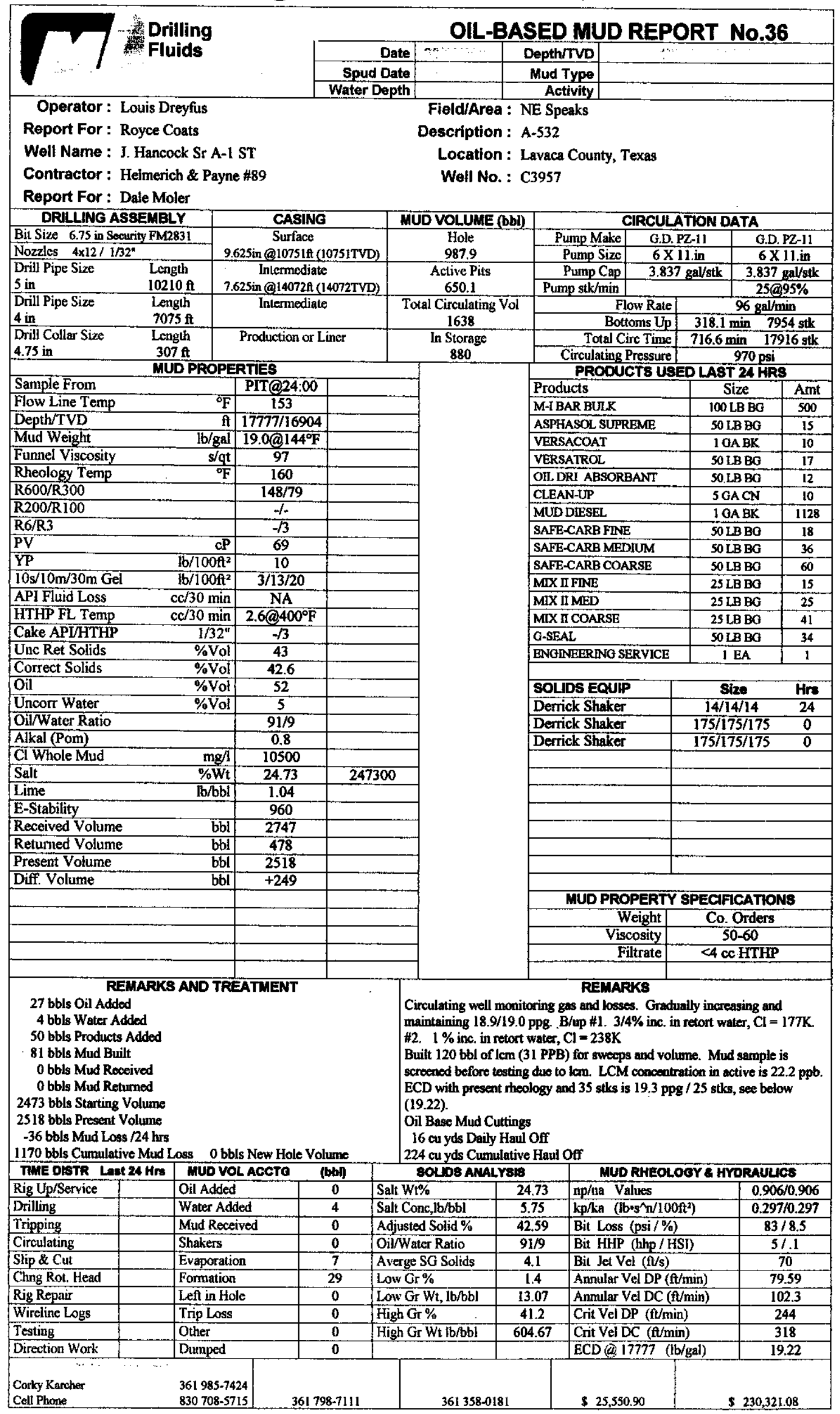




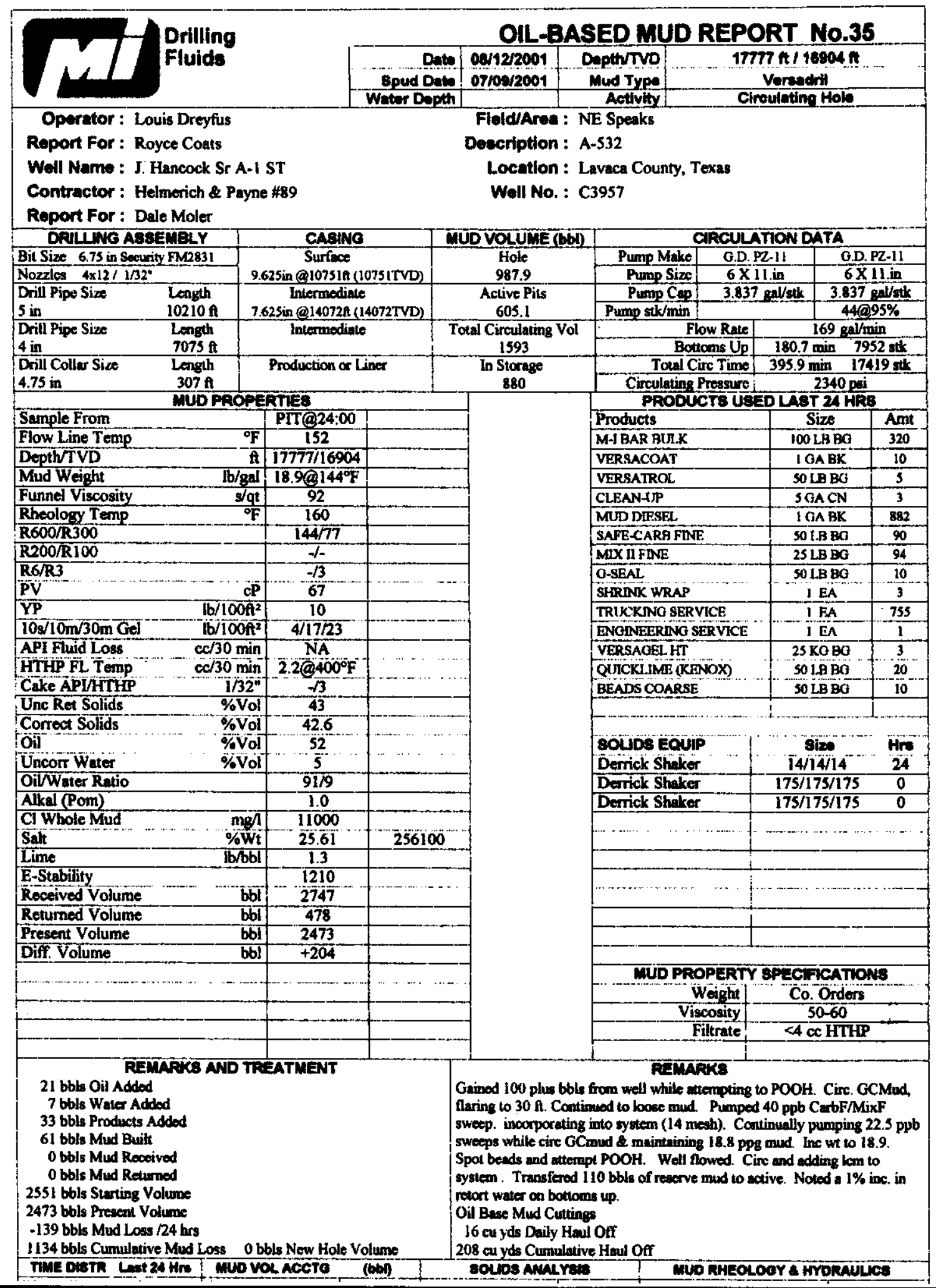




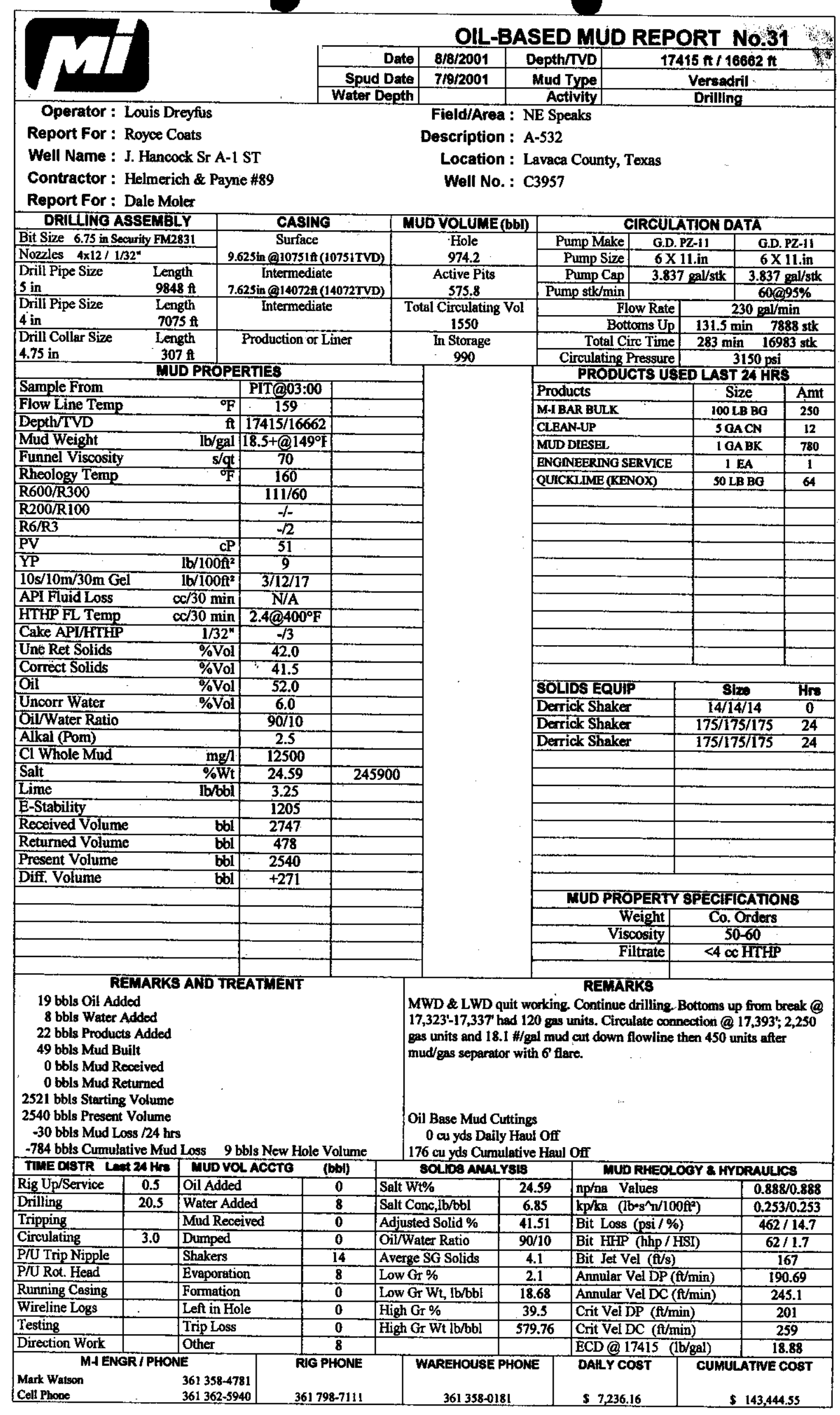


Operator : Louis Dreyfus

Report For : Royce Coats

Well Name : J. Hancock Sr A-1 ST

Contractor: Helmerich \& Payne \#89

Report For : Dale Moler

DRILLING ASSEMBLY

Bit Size 675 in Security FM0283

Nozzles 4x12/1/32"

Drill Pipe Size Length

\begin{tabular}{|ll|c|}
\hline 5 in & $9643 \mathrm{ft}$ & 7.625 in @14072ft (14072TVD) \\
\hline Drill Pipe Size & Length & Intermediate
\end{tabular}

4 in

Drill Collar Size Length

4.75 in

Length
$307 \mathrm{ft}$
Ol

\begin{tabular}{|r|c|r|c|}
\hline Date & $8 / 7 / 2001$ & Depth/TVD & $17210 \mathrm{f} / 16525 \mathrm{ft}$ \\
\hline Spud Date & $7 / 9 / 2001$ & Mud Type & Vereadril \\
\hline Water Depth & & Activity & Drilling \\
\hline
\end{tabular}

Field/Area : NE Speaks

Description : A-532

Location : Lavaca County, Texas

Well No. : C3957

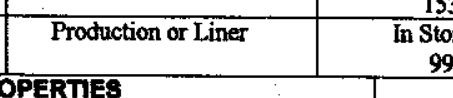

990 MUD PROPERTES

Sample From

Flow Line Temp

Depth/TVD

Mud Weight

Funnel Viscosity

Rheology Temp

R600/R300

R200/R100

$\mathrm{R} 6 / \mathrm{R} 3$

PV

YP

$10 \mathrm{~s} / 10 \mathrm{~m} / 30 \mathrm{~m} \mathrm{Ge}$

API Fluid Loss

HTHP FL Temp

Cake API/HTHP

Unc Ret Solids

Correct Solids

Oil

Uncorr Water

Oil/Water Ratio

Alkal (Pom)

Cl Whole Mud

Sailt

Lime

E-Stability

Returned Volume

Present Volume

Diff. Volume

s/qt

\begin{tabular}{r|r}
$\mathrm{cP}$ \\
$\mathrm{b} / 100 \mathrm{f}^{2}$
\end{tabular}

\begin{tabular}{r|r}
$\mathrm{lb} / 100 \mathrm{f}^{2}$ \\
$\mathrm{cc} / 30 \mathrm{~min}$
\end{tabular}

$\mathrm{cc} / 30 \mathrm{~min}$

$\%$ Vol

\%Vol

io

ad

bbl
Received Volume

\begin{tabular}{l|l|}
\hline & PIT@03:00 \\
\hline
\end{tabular}

ft $17210 / 16525$

lb/gal 18.6@144 $\mathrm{F}$

${ }^{\circ} \mathrm{F} \quad 160$

\begin{tabular}{l|l}
$107 / 58$ \\
\hline
\end{tabular}

$\frac{-1-}{49}$

$3 / 12 / 17$

N/A

$1 / 32$

\%Vol $\quad 42.0$

\begin{tabular}{l|l}
\hline 01 & 5.5 \\
\hline
\end{tabular}

\begin{tabular}{c|r} 
& $90 / 10$ \\
\hline $\mathrm{mg} / 1$ & 2.2 \\
\hline
\end{tabular}

\begin{tabular}{l|l}
$\mathrm{mg} / 1$ & 12500 \\
\hline
\end{tabular}

\begin{tabular}{c|c}
\hline $\mathrm{b} / \mathrm{bb} \mathrm{b}$ & 2.86 \\
\hline
\end{tabular}

\begin{tabular}{l|l} 
bbi & 1100 \\
\hline
\end{tabular}

\begin{tabular}{l|l} 
bbi & $\mathbf{4 7 8}$
\end{tabular}

b61 2521

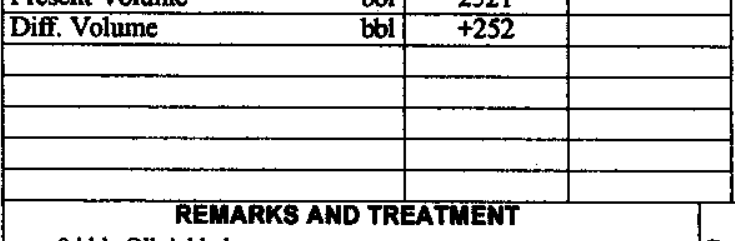

0 bbls Oil Added

16 bbls Water Added

0 bbls Products Added

16 bbls Mud Built

0 bbls Mud Received

0 bbls Mud Returned

2520 bbls Starting Volume

2521 bbls Present Volume

-15 bbls Mud Loss $/ 24$ hrs

-754 bbls Cumulative Mud Loss 2 bbls New Hole Volume

TIME DEBTR Leot 24 Hre IMUD VOL ACCTO

\begin{tabular}{l|c|l}
\hline Rig Up/Service & 0.5 & Oil Added
\end{tabular}

Drilling

Tripping

Circulating

P/U Trip Nipple

P/U Rot. Head

Chk CrownOmati

Dir. Work/Log

Ching Spinners

Chng Dir. Tools

\begin{tabular}{|c|c|l}
\hline 0.5 & Oil Added \\
\hline $\mathbf{5 . 0}$ & Water Added \\
\hline 16.0 & Mud Received \\
\hline 2.0 & Dumped \\
\hline 0.5 & Shakers \\
\hline & 0.5 & Evaporation \\
\hline $1 i$ & 1 & Formation \\
\hline 3.0 & Left in Hole \\
\hline 2.0 & Trip Loss \\
\hline 2.0 & Other \\
\hline
\end{tabular}

MHENGRI PHONE

Mark Watson

Cell Phone

$361358-4781$

$361362-5940$
RETARKS
Bottoms up from trip had maximum pas of 260 units after mud/gas separator with 18.1 \#/gal mud cut and a 15' flare. Maximum connection gas of 395 units with a $18.0 \mathrm{H} / \mathrm{gal}$ mud cut; back ground gas of 25-50 units. Last survey@ 17,141' MD/ 16,479' TVD was 48.1 degrees.

Oil Base Mud Cuttings

16 cu yds Daily Haul Off

176 cu yds Cumulative Haul Off 80 LiDs AMLLYSis

MUD PROPERTY SPECIFICATIONS

Weight Co. Orders

Viscosity $\quad 50-60$

trate $<4$ c HIHP

$1 \%$

\begin{tabular}{|c|c|c|c|c|}
\hline sis & \multicolumn{2}{|l|}{ this } & \multicolumn{2}{|c|}{ 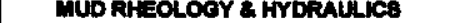 } \\
\hline 0 & Salt Wt\% & 26.24 & np/na Values & $0.883 / 0.883$ \\
\hline 16 & Salt Conc, $1 \mathrm{~b} / \mathrm{bb} 1$ & 6.85 & kp/ka $\left(\mathrm{lb}^{*} \mathrm{~s}^{\wedge} \mathrm{D} / 100 \mathrm{ft}^{2}\right)$ & $0.250 / 0.250$ \\
\hline 0 & Adjusted Solid \% & 42. & Bit Loss (psi/\%) & $464 / 13.5$ \\
\hline 0 & Oil/Water Ratio & $90 / 10$ & Bit HFP (hhp / HSI) & $62 / 1.7$ \\
\hline 4 & Averge SG Solids & 4.1 & Bit Jet Vel $(\mathrm{ft} / \mathrm{s})$ & 167 \\
\hline 0 & Low Gr\% & 2.7 & Annular Vel DP (ft/min) & 190.69 \\
\hline 0 & Low Gr Wt, Ib/bbl & 24.18 & Annular Vel DC (f $\mathrm{f} / \mathrm{min})$ & 245.1 \\
\hline 0 & High Gr \% & 39.3 & Crit Vel DP (ft/min) & 196 \\
\hline 11 & High Gr Wt lb/bbl & 578.12 & Crit Vel DC ( $\mathrm{fl} / \mathrm{min})$ & 252 \\
\hline 0 & & & ECD @ 17210 (lb/gal) & 18.96 \\
\hline
\end{tabular}

RIO PHONE

$361798-7111$

WAREHOUSE PHONE

$361358-0181$

\& $1,389,88$

5 136,208.39 


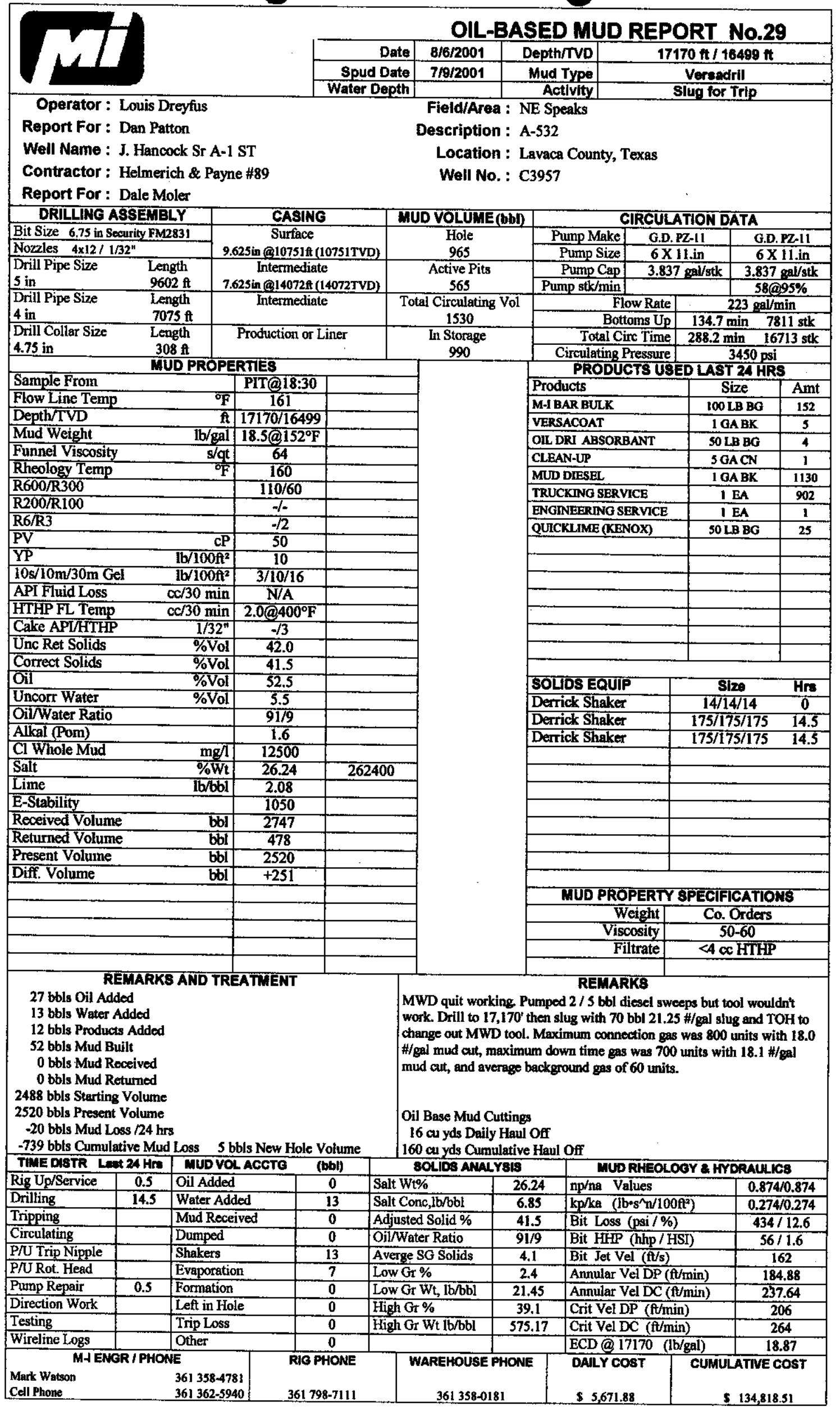


Operator : Louis Dreyfus

Report For : Dan Patton

Well Name: J. Hancock Sr A-1 ST

Contractor: Helmerich \& Payne \#69

Report For: Rick Hawthorne

DRILLING ASSEMBLY

Bit Size 0.75 in Socuriny FA2 28.31

Nozzles $4 \times 12 / 1 / 2^{\circ}$

Drill Pipe Size Length

\begin{tabular}{|ll|l|}
\hline $\mathrm{Sin}$ & $948.5 \mathrm{~A}$ & $7.62 .5 \mathrm{in}$ (9) 14072ft (140727VD) \\
\hline Drill Pipe Size & Length & Intermedigte
\end{tabular}

Length Intermediat

Drill Collar Size Length

$4.75 \mathrm{in} \quad 308 \mathrm{At}$ \begin{tabular}{|l|l|}
\hline & MUD PROPERTES \\
\hline Sample From & PIT@03:00
\end{tabular}

Flow Line Temp

Depth/TVD

Mud Weight

Funnel Viscosity

Rheology Temp

R600/R300

R200/RI00

R6/R3

PV

YP

$10 \mathrm{~s} / 10 \mathrm{~m} / 30 \mathrm{~m} \mathrm{Gel}$

API Fluid Loss

HTHP FL Temp

Cake API/HTHP

Unc Ret Solids

Correct Solids

Oil

Uncorr Water

Oil/Water Ratio

Alkal (Pom)

CI Whole Mud

Salt

Lime

E-Stability

Received Volum

Returned Volume

Present Volume

Diff. Volume

F 161

f $17053 / 16420$
OIL-BASED MUD REPORT No.28

\begin{tabular}{|r|c|c|c|}
\hline Date & $8 / 5 / 2001$ & Depth/TVD & 17053 NI/ 16420 ft \\
\hline Spud Date & $7 / 9 / 2001$ & Mud Type & Versedril \\
\hline Water Depth & & Activity & Driling \\
\hline
\end{tabular}

Field/Area : NE Speaks

Description : A-532

Location : Lavaca County, Texas

Well No. : C3957

\begin{tabular}{|c|c|}
\hline CABING & MUD VOLUME (bbl) \\
\hline Surface & Hole \\
\hline 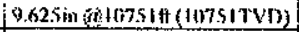 & 960.6 \\
\hline Intermediate & Active Pits \\
\hline $7.62 .5 \mathrm{in}(2.4072 \mathrm{ft}(14072 \mathrm{TVD})$ & 537.4 \\
\hline Intermediate & $\begin{array}{c}\text { Total Circulating Vol } \\
1498\end{array}$ \\
\hline Production or Liner & In Storage \\
\hline
\end{tabular}

990

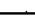

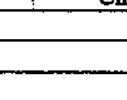

6930

\begin{tabular}{l|l|l|}
$\mathrm{lb} / \mathrm{gal} \mid 18.5:(a) 152^{\circ} \mathrm{F}$ & $18.4(\hat{a}) 165 \mathrm{~F}$ \\
\hline
\end{tabular}

B/U From

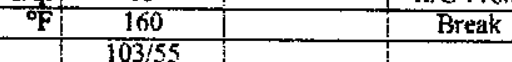

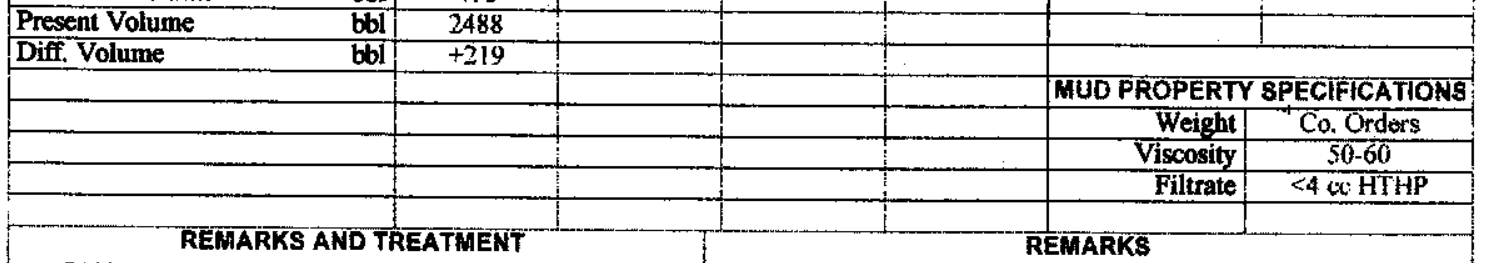

7 hbis Oil Added

16 bbls Water Added

25 bbls Products Added

48 bbls Mud Built

239 bbls Mud Received

228 bbls Mud Returned

2505 bols Sterting Volume

2488 bbls Present Volume

-76 hbls Mud Loss $/ 24$ hrs

.710 bbls Cumulative Mud

8 bbls Niew Holc Volum:

\begin{tabular}{|c|c|c|}
\hline IIME WSTIK Last $24 \mathrm{HIS}$ & MUD YOL ACCTO \\
\hline Rig Up/Service & 0.5 & Oil Added \\
\hline
\end{tabular}

Drilting

Tripping

Circulating

P/U Trip Nipple

P/U Rot. Head

Dir Survey

Direction Work

Testing

Wireline Logs

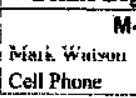
MHENGR I PHONE

\begin{tabular}{|c|l|}
\hline 22.5 & Water Added \\
\hline 2.0 & Mud Received \\
\hline 4.0 & Dumped \\
\hline 0.5 & Shakers \\
\hline 0.5 & Evaporation \\
\hline & Formation \\
\hline & Left in Hole \\
\hline & Trip Loss \\
\hline & Other \\
\hline
\end{tabular}

364 3.58-4781

$361362-5940$
Made short trip to liner (a) 16,885'. Bottoms up had 300 gas units after mud/gas separator with a $20^{\prime}$ flare. Sxapped 500 bbls from system with 500 bbls new nud; ROP increased. Hottoms up trons drilling brcak ( $\omega$ 16,925 ' had 150 gas units after mud/gas separator with no flare. Maximum comnection gas was 700 units with $18.2 \mathrm{H} / \mathrm{gal}$ mud cut. Maxinum down time gas was 575 units with 18.2 \#/gal mud cut. Background gas @ 60 turils. Latst survey @ 16.949' wats 48.3 degrees.

Oil Base Mud Cuttings

32 cı yds Daily Haul off

144 cu yds Cumulative Hanl Of:

SOLIOS AMAA YS 18

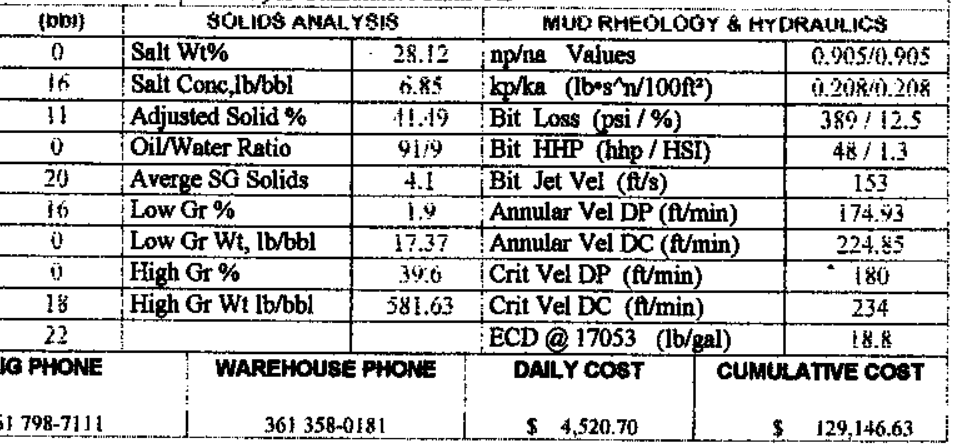




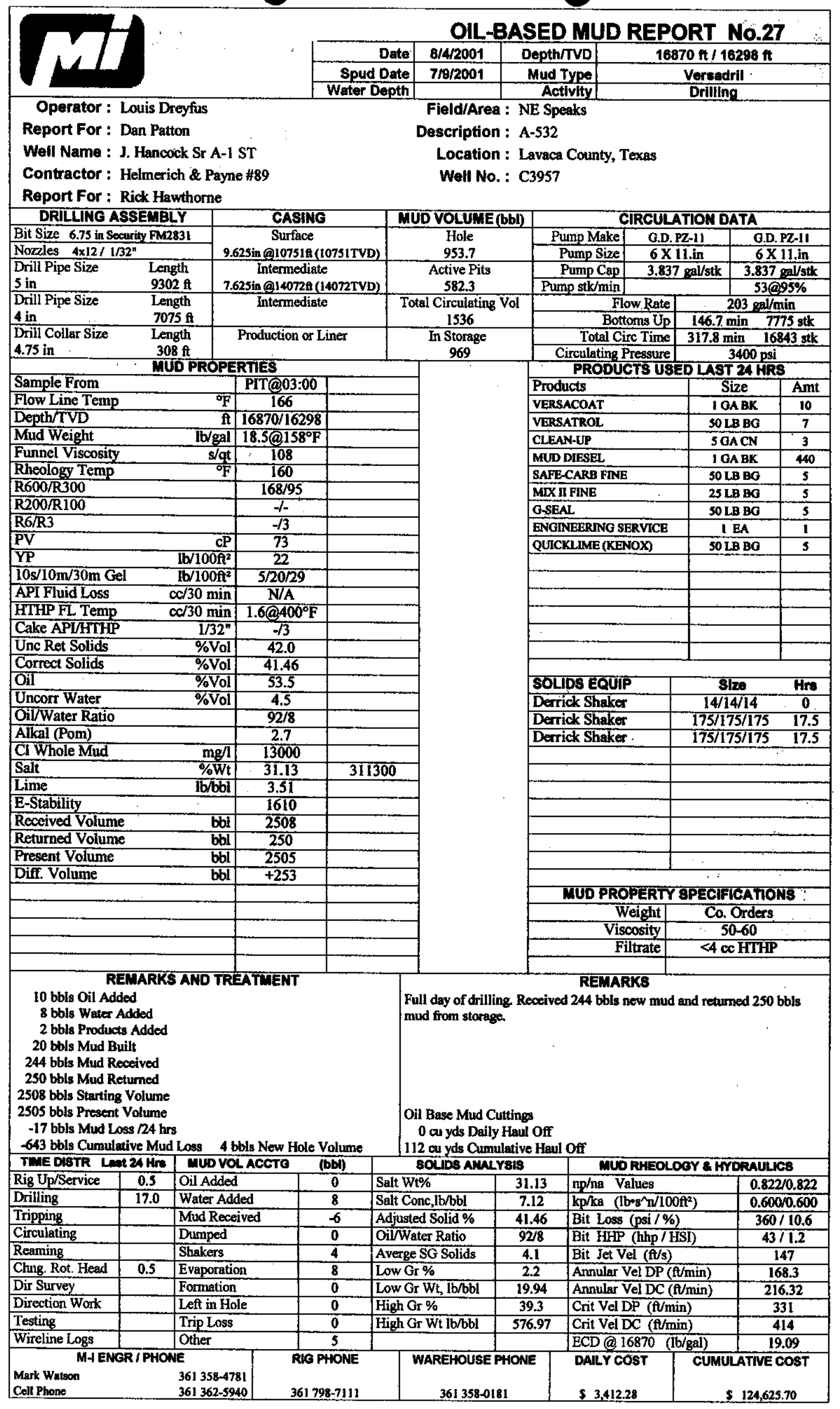




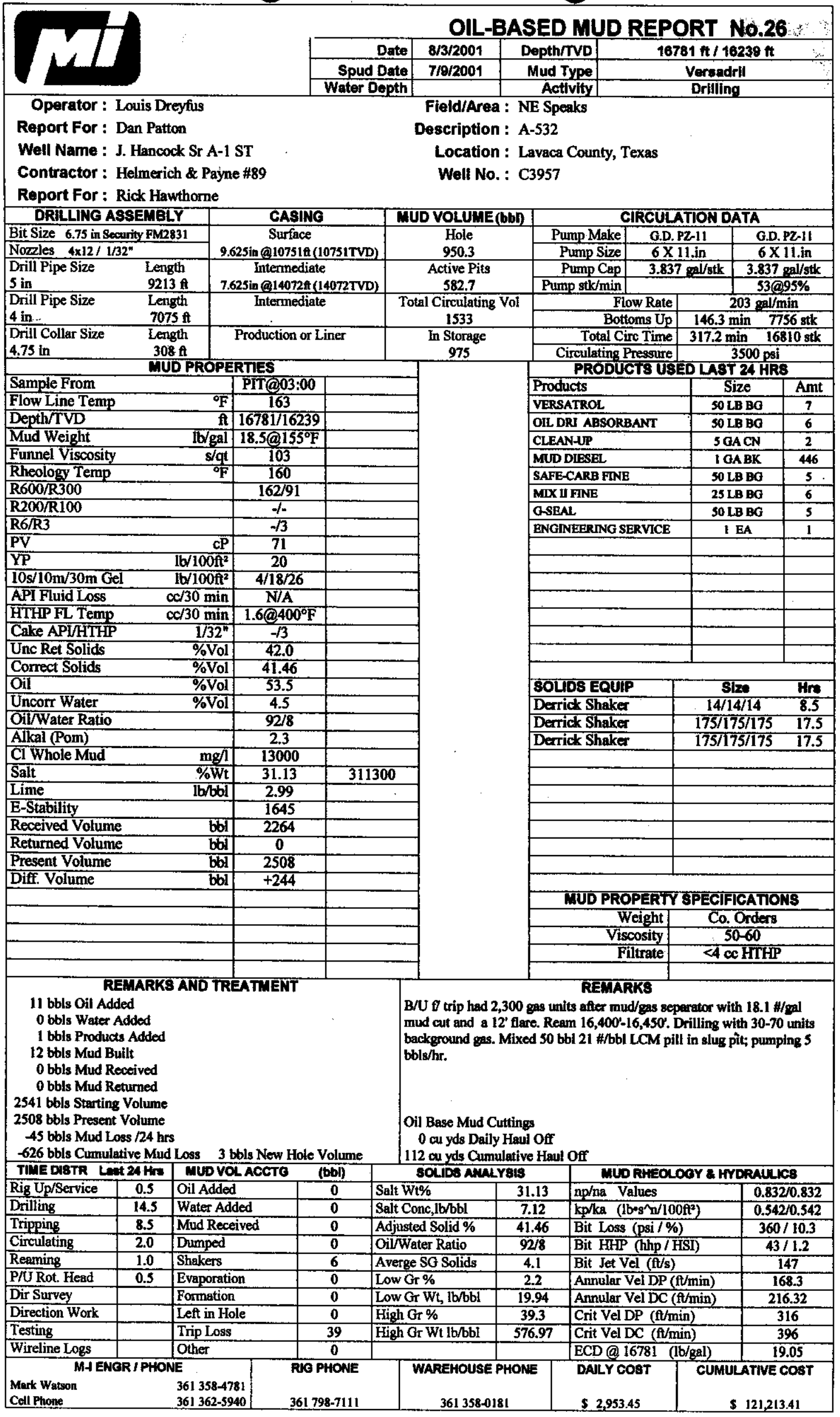




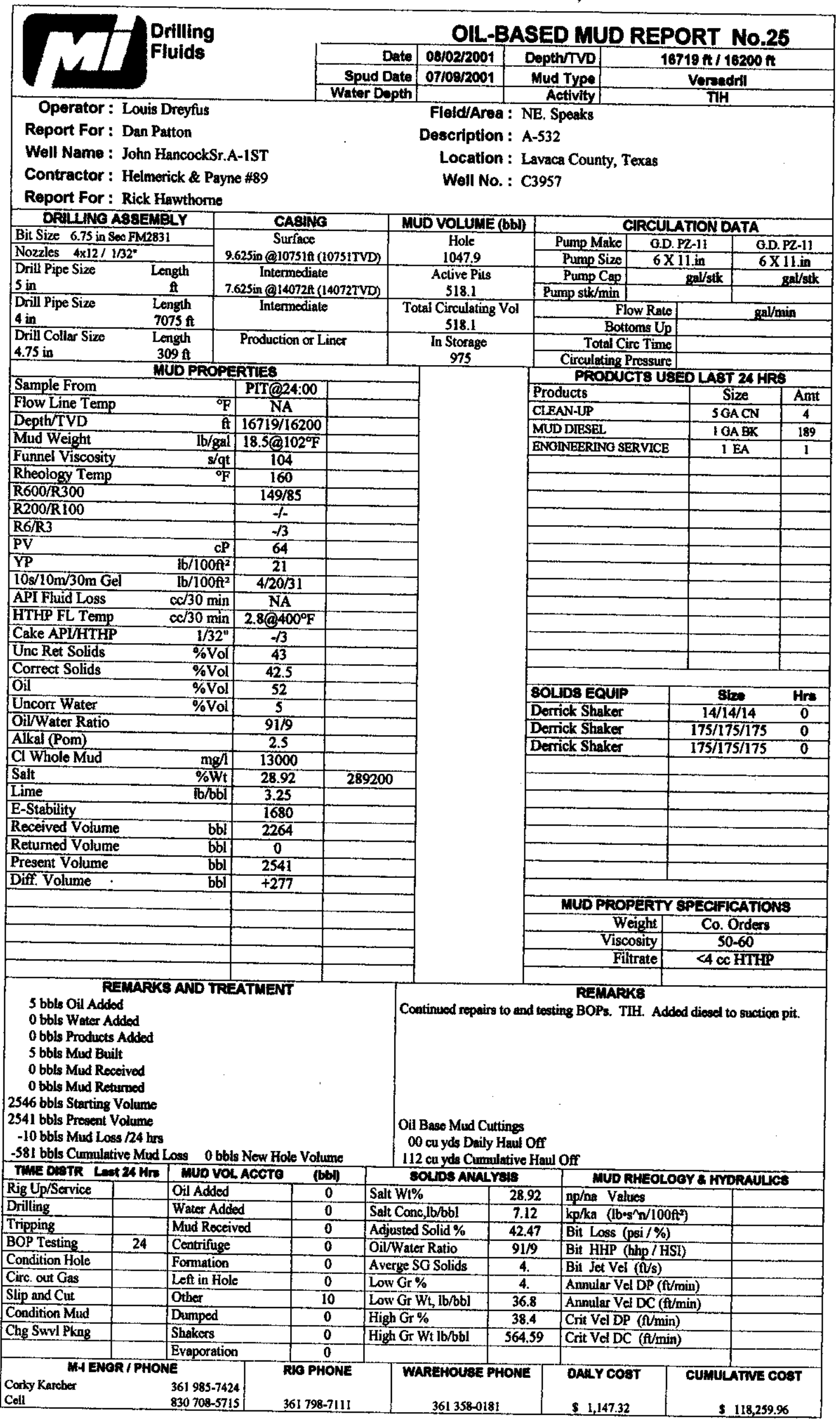




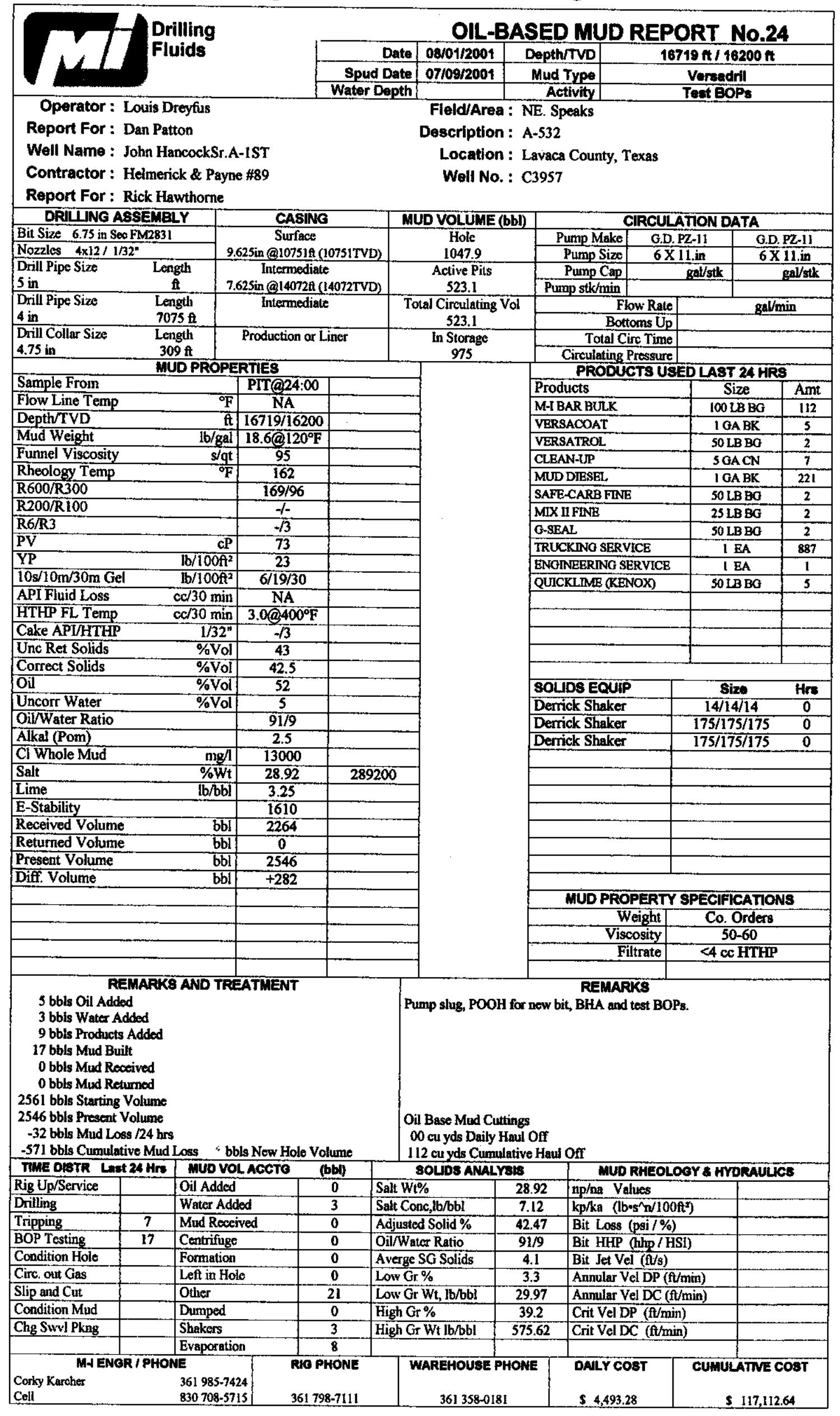




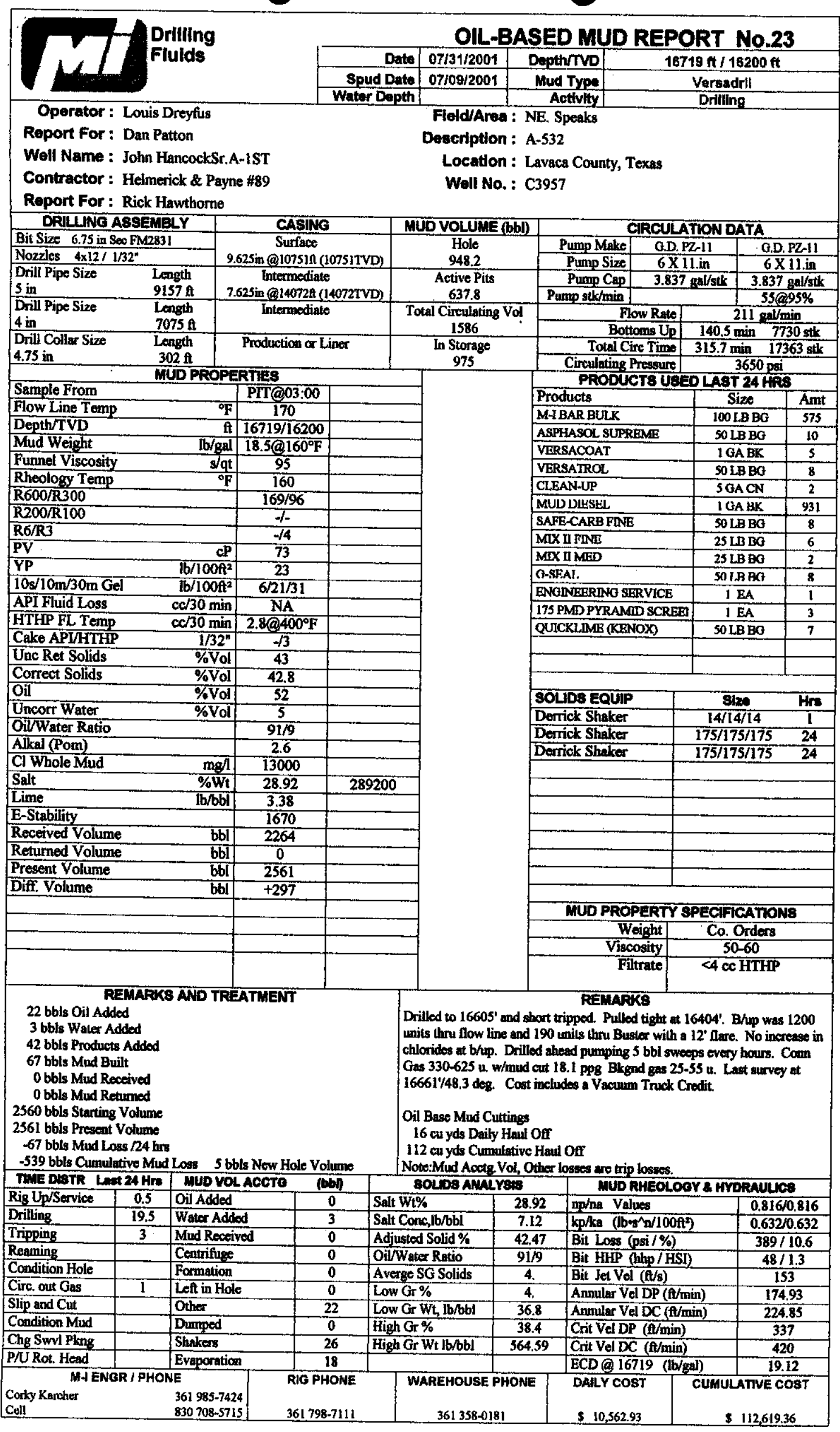




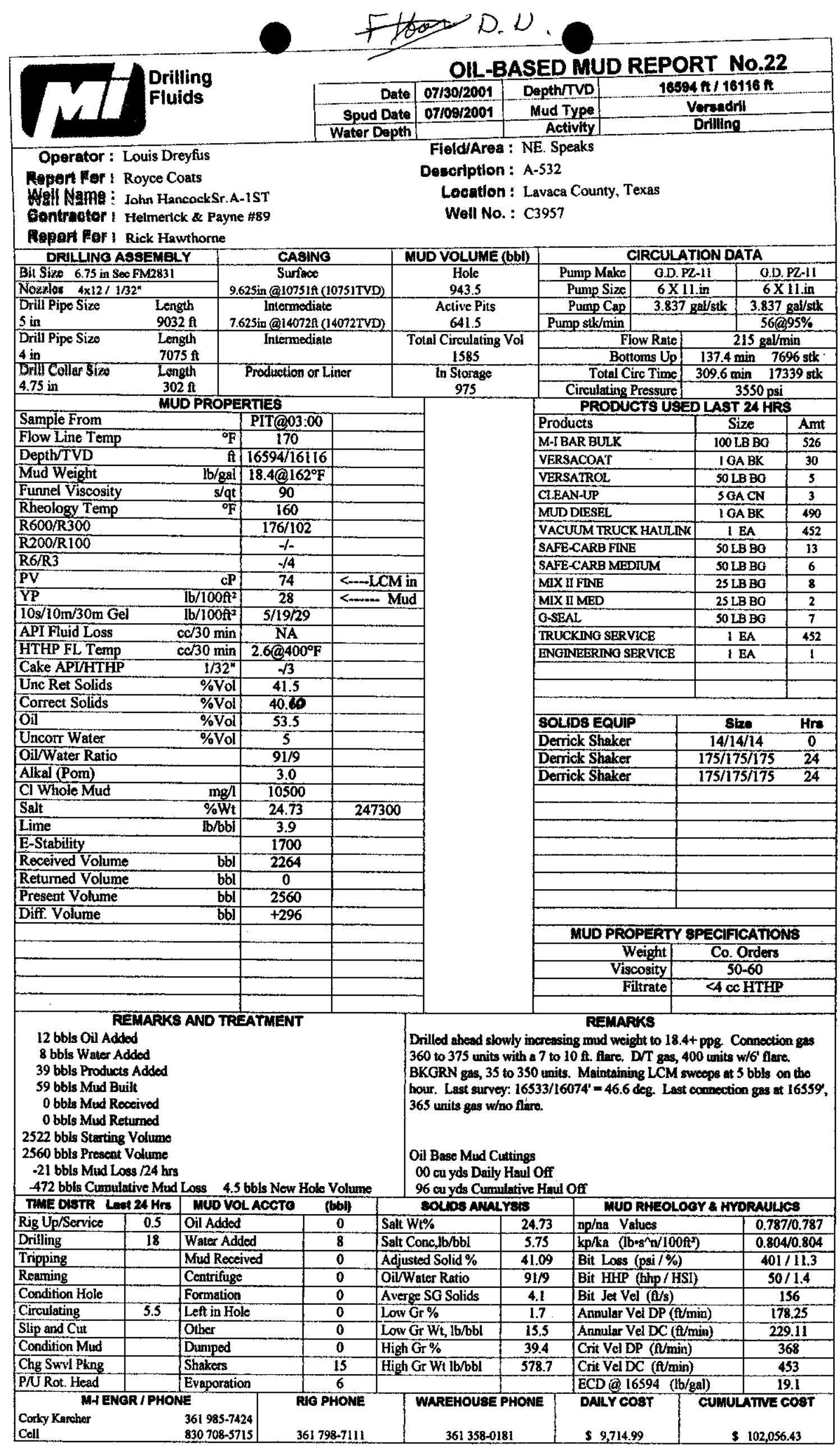




\section{Digital Data}

- INSITE adi backup with Data directory on MO disk 


\section{Miscellaneous}

